\title{
The Corpus of the Greek Medical Papyri and a New Concept of Digital Critical Edition
}

\section{Defining and shaping a digital critical edition}

Traditionally and basically, a critical edition of a text is the printed output of a philological work, i.e. the process of reconstruction of a textual archetype (the 'source') among different variants, aimed at reproducing the original text as most exactly as possible, or, in other terms, as the fixed representation of a scholar's more or less trustable opinion on that text. Accordingly, and rather intuitively, a digital critical edition should be defined as the digital output of a philological work. We will see what a "digital output" involves in methodological and epistemological terms but, to start, it must be noted that traditionally a digital critical edition is regarded as the digital transfer of a printed critical edition. Sometimes, this process regretfully gets rid of the attribute 'critical', so that we have digital editions or textual corpora deprived of apparatus criticus and therefore 'uncritical', as in the well-known cases of the Thesaurus Linguae Graecae or of the Perseus Digital Library. This treatment presents encoding advantages, since one reference edition is chosen and digitized, but also huge disadvantages in terms of usability, because search and analysis functions are limited to the chosen text, without consideration, e.g., for textual variants, alternatives or different editorial solutions. ${ }^{1}$ Somewhat 'hybrid' editions try to save the constitutio textus (the restitution of a text as close as possible to the supposed original) alongside the recording of variant readings: for example, the former Duke Databank of Documentary Papyri with the spelling variants (as written on the original papyrus) embedded within the 'normalized' text with special markup. ${ }^{2} \mathrm{~A}$ fairer transfer process preserves the apparatus criticus, which is usually displayed in a way that resembles the printed edition. The simplest examples are PDF editions (either scans of paper samples or born-digital files like the publications of the PHerc project), ${ }^{3}$ the most articulated ones are the digital editions available at the Papyri.info platform, where critical annotations, encoded as inline XML markup elements, are processed and displayed in an

\footnotetext{
The present contribution is published in the framework of the Project "Online Humanities Scholarship: A Digital Medical Library Based on Ancient Texts” (DIGMEDTEXT, Principal Investigator Professor Isabella Andorlini), funded by the European Research Council (Advanced Grant no. 339828) at the University of Parma (http://www.papirologia.unipr.it/ERC).

1 See already DEgAni 1992, and more recently MaGnANi 2008, 135-7; also M. Magnani in this volume.

2 Cf. REgGiani 2017, 215-7.

3 Cf. ReGGIANI 2017, 176.
}

Ә Open Access. () 2018 Nicola Reggiani, published by De Gruyter. (c))BY-NC-ND This work is licensed under the Creative Commons Attribution-NonCommercial-NoDerivatives 4.0 License. 
apparatus of print-like format, stressing the distance between the 'correct' text and alternatives, variants, actual textual features.

\begin{tabular}{|c|c|c|c|}
\hline 10 & 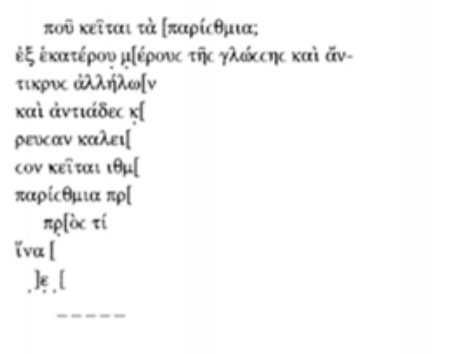 & 10 & 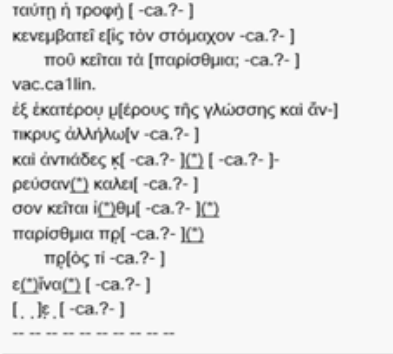 \\
\hline \multicolumn{2}{|c|}{ 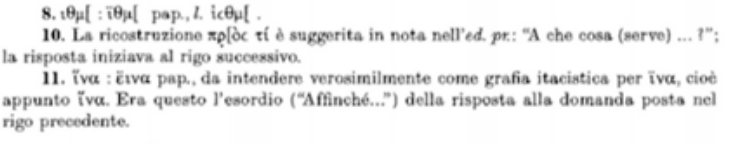 } & & 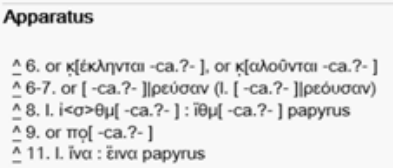 \\
\hline
\end{tabular}

Fig. 1: PSI XV 1510, medical catechism on anatomy, III cent. AD: printed edition and digital edition at http://litpap.info/dclp/64024.

This traditional view is being challenged as rather uncomfortable by the development of digital technologies in the ancient studies, as well as by an increasing concern for the actual testimonies and the process of textual tradition: we may define it as a sort of 'phenomenological' approach. Digital projects like the Homer Multitext Project (HMT) or the Leipzig Open Fragmentary Texts Series (LOFTS) started envisaging a different approach to textual criticism, in deploying a text that is in fact a multitext, a fluid and dynamic network of multiple editions aligned to each other (by means of a URN architecture) rather than a traditional fixed structure of text and apparatus criticus, ${ }^{4}$ In this framework, the uneasiness of texts that are felt not being completely suitable for a 'traditional' critical edition (e.g. oral Homeric poetry, ${ }^{5}$ fragmentary

4 A multitext is basically a dynamic collection of multiple critical editions, a network of versions with a single root. As Monica Berti described it, “[i]t produces a representation and visualization of textual transmission completely different from print conventions, where the text that is reconstructed by the editor is separated from the critical apparatus that is printed at the bottom of the page. [... It] allows the reader to have a dynamic visualization of the textual tradition and to perceive the different channels of both the transmission and philological production of the text that is usually hidden in the static, concise, and necessarily selective critical apparatuses of standard printed editions. Producing a multitext, therefore, means producing multiple versions of the same text, which are the representation of the different steps of its transmission and reconstruction, from manuscript variants to philological conjectures” (BERTI forthcoming, 4). Cf. REGGIANI 2017, $266 \mathrm{ff.}$

5 The HMT project concept results from the statement that the Homeric textual evidence does not comply with the traditional philological view of textual variants stemming from one archetype, since 
sources $^{6}$ ) merges with the new capabilities of digital infrastructures, which offer much more dimensions than printed paper. Hypertext is a new writing space, to which editors have to adapt the texts: ${ }^{7}$

[o]nce we are able to overcome the physical limits of printed editions by joining together variants and conjectures referring to the same texts, it also becomes possible to look at the texts from a new and broader perspective, with possible consequences for our knowledge and comprehension of them. ${ }^{8}$

Thence, an unavoidable fact:

[w] need to move in the direction of digitally conceived and initiated types of information and away from mopping up information from print sources. ${ }^{9}$

As it has been put very effectively, the hypertext architecture is challenging the Urtext model, ${ }^{10}$ and it paves the way for exploring the possibilities of "holistic" models where editorial choices are superseded by an interactive network of all extant data, with potentially infinite information layers. ${ }^{11}$ Perhaps, the model that better describes this ideal condition is an ontology design:

an ontology is the most suitable solution to represent critical editions of ancient texts for two main reasons: first, we want to be able to link different kinds of resources [...] that have in common the possibility of being referred to via URIs, which is one of the principles of the Semantic Web; second, information contained in critical editions constitutes a layer of interpretation and a description of relations about texts that is important to keep clearly distinct from the texts themselves. Indeed, the use of stand-off metadata encoded within ontology allows us to express an open-ended number of interpretations, whereas a markup-based solution would not make this possible due to obvious reasons of overlapping hierarchies. ${ }^{12}$

a true original Homeric text never existed (cf. BIRD 2010): a somehow "agnostic" (BODARD - GARCÉS 2009, $96 \mathrm{n}$. 31) environment where all witnesses are transcribed and juxtaposed, without preference for any of them. See M. Magnani's chapter in the present volume for a critical view of this idea.

6 Ancient fragments are characterized by a high level of textual complexity, in the relationships among the actual text in which they are embedded, its critical edition (interpretation), the original source (attribution), the quoting source (witness), etc.: cf. BERTI forthcoming.

7 Cf. BOLTER 1991; REGGIANI 2017, $263 \mathrm{ff}$.

8 RomANELlo - BerTi - BoschetTI - BABEU - CRANE 2009, 165

9 BAGNALL-GAGOS 2007, 74.

10 BOLTER 1991.

11 Cf. BODARD - GARCÉS 2009

12 RomANELlo - BerTi - BOSCHETtI - BABEU - CRANE 2009, 158. An ontology is a formal definition of types, properties, and interrelationships of the entities belonging to a certain domain of knowledge. In other words, it compartmentalizes the variables needed for some set of computations and establishes the relationships between them. 


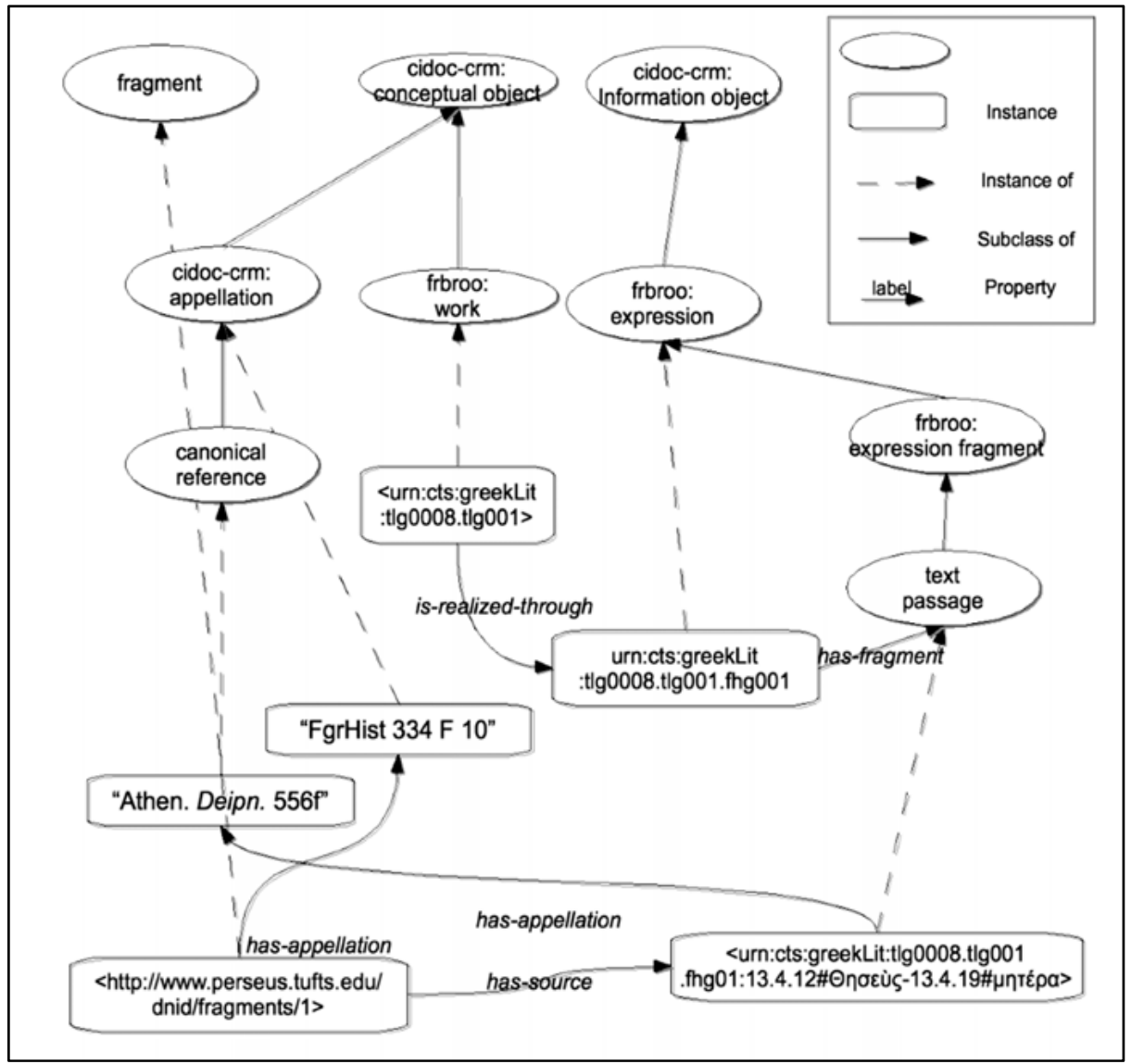

Fig. 2: A sample ontology model (from RomANeLLO - BERTI - BOSCHETTI - BABEU - CRANE 2009, 167).

\section{Papyrology: philology in flux}

Papyrology is, in its more essential core, all about providing trustable critical editions (and commentaries) of papyrus texts. ${ }^{13}$ Though projected towards a broad historical and cultural evaluation of the textual data, ${ }^{14}$ it is intimately a philological discipline: ${ }^{15}$ no one can deny that without texts there would exist no Papyrology. Yet it is a very peculiar philological discipline, since it is well aware of the fluidity of its objects of

13 Cf. Youtie 1963, 22-3.

14 Cf. e.g. BAGNALL 1995.

15 Cf. HANSON 2002, 196; SCHUBERT 2009, 197. 
study: ${ }^{16}$ texts are continuously published, updated, collected, revised, corrected, emended, republished, and there is hunger for resources that can help handling an overwhelming amount of primary data. ${ }^{17}$ It is - to borrow the successful concept that Zygmunt Bauman launched to emphasize the fact of change in the modern times ${ }^{18}$ a 'liquid' philology, for which digital environments seem extremely fitting; in particular, collaborative platforms like SoSOL seem the most suitable incarnation of this complex and fluid editorial workflow. ${ }^{19}$

Moreover, Papyrology has always been facing an adventurous textual situation, having to cope with fragmentary and unique texts and idiosyncratic utterances, and has developed a remarkable interest in the scribal and material phenomenology of textual features and transmission, which affects consistency in treating the wide series of textual fluctuations occurring in the papyri. Indeed, while philological analysis would gladly treat fluctuations as deviations from a standard archetype (i.e. mistakes or, more gently, variants) and normalize them in a reconstructed critical edition, they actually bear significant socio-cultural relevance and are of fundamental importance from the viewpoint of the phenomenology of the papyrus texts, its interpretation, and ancient writing culture in general. In other words, very often fluctuations are not used to reconstruct a text but to investigate relevant socio-cultural phenomena. Accordingly, the papyrologists' behaviour towards such textual flavours is twofold, and generates a wide variety of editorial inconsistencies that affect printed editions as well as digital databanks.

As to the latter, the issue at stake is not only critical agreement or scholarly standards, but also (as hinted above) the usability of the tools themselves, in terms of searching and encoding. The best example, from my own experience, is the case of the word $\dot{\varepsilon} \mu \eta \nu \varepsilon i \alpha$, which often occurs in the papyri in the iotacistic form $\dot{\varepsilon} \rho \mu \eta v i \alpha$. The spelling 'variant' is treated differently in the printed editions, being sometimes 'regularized' in the apparatus, sometimes not, generating textual inconsistencies even within the very same text. ${ }^{20}$ In BGU I 326, ii $15 \dot{\varepsilon} \rho \mu \eta v i \alpha$ is printed without apparatus notes, and it is reproduced in the databank as such; in the same text, at $1 . i 1$ the same word is supplied as $\dot{\varepsilon} \mu \eta \nu \varepsilon i] \alpha$ (following the 'standard' form) in the database, while all the printed editions (after the ed.pr.: Chr.M. 316; Sel.Pap. I 85; FIRA ${ }^{2}$ III 50; Jur.Pap. 25) keep the 'variant' in the lacuna too. Another 'classical' case is that of the

16 Cf. Youtie 1963, 27-32; HANSON 2002, passim; SCHUBERT 2009, $212-3$.

17 As I pinpointed in REGGIANI 2017, 2-6, this is the basic raison d'être of Digital Papyrology.

18 Cf. e.g. Bauman 2000; 2007; 2011.

19 On the collaborative structure of the database cf. REGGIANI 2017, $232 \mathrm{ff}$. All editorial interventions are kept recorded in a "History" log, which is available to every user: see L. Berkes' article in this same volume for a screenshot of a sample editorial history on Papyri.info.

20 Cf. REGGIANI 2018a. Some remarks on the inconsistent treatment of iotacism can be found also in J. Stolk's and M. Vierros' contribution to this volume. 


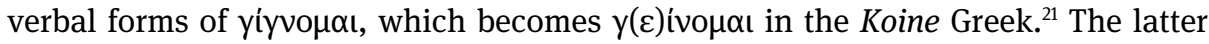
forms are indeed treated as the standard in most of the papyrus editions, and therefore are not 'regularized' as variants, ${ }^{22}$ but this is not always consistent: editorial regularizations do occur, seemingly only when the verb is affected also by iotacism, often in compounds. ${ }^{23}$ On the other hand, we do find the classical Greek forms not being regularized as well, ${ }^{24}$ which increases the uneasiness of anyone who would like to perform effective searches in the digital textual corpora. With the further developments of the Greek language, the situation is even more complex: for example, the general shift from dative to genitive in the later (Byzantine) instances of the language of the papyri ${ }^{25}$ leads to further editorial inconsistencies. In BGU XIII 2332,20 (AD 375),

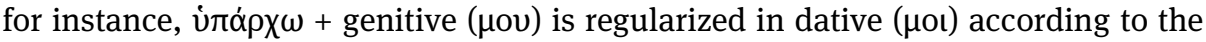

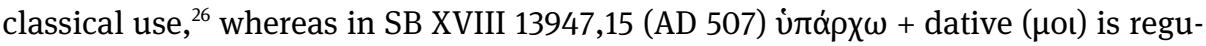
larized in genitive ( $\mu \mathrm{ov})$ as if the latter was then the correct form. ${ }^{27}$ One must be aware of any possible spelling or syntactic combination to perform trustable textual searches. ${ }^{28}$

As is apparent, papyrus texts carry a cognitive complex that is often hard to fit into printed editions and may find its better representation in the digital space, where the objects of study undergo a process of dematerialization. I have already argued that the development of Digital Papyrology, in its treatment of computerized information about papyri, produced the effect of working on the virtual representation (avatar) of the papyri themselves, which turn to be meta-texts, ${ }^{29}$ in the terms already envisaged by Traianos Gagos as early as 1998:

In this new era of papyrological research, we cannot speak of a collection of papyri alone, but also of a collection of electronic files, data, metadata and digital images: ${ }^{30}$

21 Cf. Depauw - Stolk 2015 and J. Stolk's chapter in this volume.

22 A quick survey of a sample search in Papyri.info can give a global idea of this trend: http://

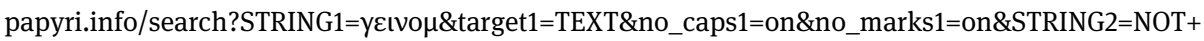
yıvo\&target2=TEXT\&no_caps2=on\&no_marks2=on.

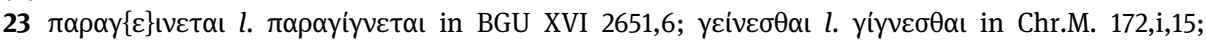

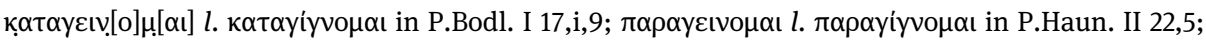

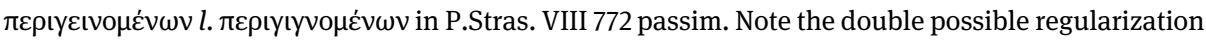

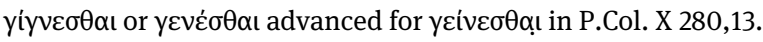

24 Another sample search: http://papyri.info/search?STRING1=yıyvop\&target1=TEXT\&no_caps1= on\&no_marks1=on.

25 Cf. STOLK 2015b.

26 For more similar cases cf. STOLK 2015a, 85 ff., and 2015b.

27 Cf. Depauw - Stolk 2015, 213. See also Stolk 2015a, 93.

28 On these topics cf. REGGIANI 2018a, 2018b, 2018c, and J. Stolk in this volume.

29 Cf. REGGIANI 2017, $260 \mathrm{ff}$.

30 GAGOS 2001, 516. 
The availability of huge amounts of information in fully searchable textual form with accompanying images through these new media is altering drastically the definition of what constitutes a 'text', the way we experience reading it and, ultimately, the plurality of messages a text can offer to one or more readers. The new methods of presenting text with marked up images and the simultaneous availability of a variety of other research tools within the same electronic environment give us new ways of visualizing and approaching a given text. An edited text is no more a static, isolated object, but a growing and changeable amalgam: the image allows the user to look critically at the 'established' text and to challenge continuously the authoritative readings and interpretation of its first or subsequent editors.

Furthermore, the simultaneous access to and study of thousands of texts and their images that could be as far apart as a millennium, in a single search and through the same medium, has the potential to challenge our established notions of the 'messages' a text carries within itself, its textuality and intertextuality [...]. As Roland Barth [sic] explains: 'Any text is an intertext; other texts are present in it, at varying levels, in more or less recognizable forms: the texts of the previous and surrounding cultures. Any text is a new tissue of past citations. Bits of codes, formulae, rhythmic models, fragments of social languages, etc. pass into the text and are redistributed within it, for there is always language before and around the text'. In one or another way, papyrologists have always recognized the "intertextuality" of the Greek papyri from Egypt, because of the multicultural and multi-ethnic environment in which these texts were born. The development of the new electronic media in our field and the capability to establish these cross-links or these intertextual signifiers, so to speak - on the linguistic, cultural and historical level through the interaction of multiple texts, images and a variety of related tools places the notions of textuality, intertextuality and metatextuality on a new (electronic) platform which, in turn, becomes part of these notions as the 'carrier', 'interpreter' and 'distributor' of these texts. ${ }^{31}$

The concept that Digital Papyrology redefines the notion of 'papyrus' is embedded in the consideration that

these media, when used within a wider intellectual perspective as a cognitive tool for research and instruction and not only as a pragmatic medium that can 'do certain things for us', can challenge and redefine notions of 'text' and textuality. ${ }^{32}$

After realizing that we are coping with enhanced papyri that are in fact 'meta-papyri', we need to reshape the digital edition in accordance with the nature of the papyrological digital data as autonomous intellectual objects (following the definition of what is 'data' for the humanists according to OwENS 2011), ${ }^{33}$ and the possibilities offered by the electronic meta-space. ${ }^{34}$ There is a momentous chance to see the digital document not as the mere, more or less complete reproduction of a printed critical

31 GAGOS 2001, 514-6.

32 GAGOS 2001, 515 n. 8.

33 At the same time constructed artefacts, being created by people, and interpretable texts, they "can hold the same potential evidentiary value as any other kind of artifacts".

34 See also the observations by M. Magnani in this volume. 
edition, but as a quantum particle of a fluid universe of text transmission. This 'dispositive' - in foucaldian terms ${ }^{35}$ - may find a suitable representation through the abovementioned ontology design, where we do not have to decide what is 'regular' or 'normal' and what is a 'secondary' reading, but can create an interconnected network of aligned versions, which represent different possible layers of textuality: ${ }^{36}$

[o]nly with a comprehensive understanding of the content and assumptions of the traditional hughly-evolved critical apparatuses will we make the right strategic decisions for the future of textual scholarship. ${ }^{37}$

Philology tends to overcome any textual fluctuation in favour of a reconstructed text that be as closest as possible to the 'original' source, but documentary papyri are actually the original source of themselves (any critical interventions being configured as the reconstruction of an imaginary archetype), while literary and paraliterary papyri present more complex issues, as introduced below. They are therefore among the best text typologies suitable for exploring new ways of conceiving digital critical editions.

\section{The medical papyri: special technical needs of a special technical corpus}

Within the framework sketched above, the Digital Corpus of the Greek Medical Papyri project ${ }^{38}$ proved pathbreaking in applying the notion of digital edition to literary and paraliterary papyri, previously excluded from Papyri.info and object of very specific and isolated projects (CPP, THV etc.). The project stemmed from Isabella Andorlini's lifelong interest in the medical papyri and from her own challenge to collect them in

35 LAMÉ 2014 describes this idea (with reference to ancient epigraphs) through Foucault's philosophical concept of dispositive: the message of the text-bearing object can be completely understood in relation with a complex network of many other heterogeneous pieces of information. The ultimate purpose is "to digitize also the network that connected those information systems, instead of digitizing each individually".

36 The platform Sematia, discussed by M. Vierros in this volume, is a nice example of how the transcription of the actual papyrus text can be aligned to a 'regularized' layer of the same text, so that any possible information is kept in an interactive way.

37 DAMON 2016, 218.

38 With DCGMP I refer to the whole digital corpus of the Greek medical papyri as resulted from the work of the DIGMEDTEXT project mentioned in the Introduction to this volume. The title Corpus dei Papiri Greci di Medicina Online ("Online Corpus of the Greek Medical Papyri”) refers to the first stages of the project. Bibliography: ANDORLINI - REGGIANI 2012; REGGIANI 2015; 2016a; 2017, 273-5; ANDORLINI 2017; BERTONAZZI 2018a, 24-9; REGGIANI 2018b; http://www.papirologia.unipr.it/CPGM. 
a uniform and homogeneous corpus. ${ }^{39}$ Her first steps went towards the printed medium, ${ }^{40}$ but she soon realized the strong potentials of Papyri.info to host dynamic papyrological editions, ${ }^{41}$ and her project later became one of the leading pilot test cases of the rising Digital Corpus of Literary Papyrology ${ }^{42}$ in envisaging new technical and theoretical strategies for the encoding of literary and paraliterary texts, eventually awarded with an ERC advanced grant (http://www.papirologia.unipr.it/ERC).

Medical papyri are technical texts: they have been conceived to convey a technical knowledge, i.e. theoretical and practical specialized information at the same time - a knowledge that is, in turn, mirrored and refracted in the different written genres encompassed by the corpus. ${ }^{43}$ The importance of medical technical skills is apparent, and not only for health reasons (think of Galen's instructions to the patients so that they can choose the best doctor after an enquiry on his skills): ${ }^{44}$ one might recall P.Oxy. I 40 (+ BL I 312, V 74, VI 95; Oxyrhynchus, II cent. AD), a copy of the report of a court judgement where a public doctor claims for immunity from some liturgies, and the judge, after a rather witty remark, requests a scientific proof of his assertion. ${ }^{45}$ The importance of written text for this education is stressed as earlier as in the Hippocratic corpus: "I consider the ability to evaluate correctly what has been written as an important part of the art" - says the author of the Epidemics - "He who has knowledge of it and knows how to use it will not commit, in my opinion, serious errors in the professional practice" (Epid. III 16 = III 10,7 ff. L.). In fact, the transmission of this knowledge was carefully carried out through a specialized education, which was based on oral teachings later entrusted to written supports. In the introduction to the treatise On his own books, Galen himself explains how in the context of the oral lesson one used to take written notes, thence moving to the publication of memoranda, the hypomnemata of the lessons heard. ${ }^{46}$

Stemming from both the knowledge of oral teaching and the know-how of practical records and individual experience, every medical writing is not a fixed book but a tool in flux: the older treatises are annotated, commented, collated often against annotated and commented copies, ${ }^{47}$ transcribed with additions, corrections, and updates; the collections of personal notes on clinical cases, therapies or remedies are

39 Cf. REGGIANI 2018d.

40 Cf. ANDORLINI 1997a.

41 Cf. ANDORLINI - REgGiani 2012, 138-9; BAGNALL 2012, 4.

42 See the chapter by R. Ast and H. Essler in this volume.

43 Cf. ANDORLINI 1993; REGGIANi 2018e.

44 Cf. NutTon 1990.

45 On official examinations of physicians see REGGIANI $2018 \mathrm{f}$.

46 Cf. NuTTON 1972; NiEDDU 1992, 555-7; ANDORLINI 2003, 14.

47 On the collation of annotated copies, always according to Galen's words (In Hp. Off. III $22=$ XVIIIb 863,14-865,5 K.; In Hp. Epid. II 8 = XVIIa 634,3-7 K.), cf. ANDORLINI 2003, 15, who recalls (note 15) the story of Mnemon, who took the third book of Hippocrates' Epidemics from the library of Alexandria 
constantly revised on the ground of practice; prescriptions are transcribed, exchanged, collected, gathered in the receptaria and passed down; handbooks of different typologies are used to teach again, and so on, keeping on the written support traces of every stage of transmission and use. ${ }^{48}$

Such texts are further characterized by intertextual and transtextual connections: references, quotations, more or less literal parallels, are another key to understand and contextualize the matter at the best. The recipes, and their collections known as receptaria, find inspiration in the pharmacological treatises and are further enriched by the doctors' personal practice and by references and quotations from different medical sources; the questionnaires are connected to the literary tradition of the Definitiones medicae (see below). These are by no means stemmatological relationships between ascendants and descendants: it is a fluid knowledge undergoing continuous changes, updates, adaptations, much influenced by oral teaching and actual practice. Accordingly, the very textual data interweave with a huge panel of textual devices, which contribute to articulate an expressive network that is essential to the medical writing itself, to its transmission, to its learning, and to its practical use: therefore, they deserve a particularly careful consideration. Critical and diacritical marks, punctuation, graphical and layout features, technical terms and formulae, literary or sub-literary references or echoes, marginal annotations - to cite the most outstanding devices - form a complex interplay that cannot be separated from the text itself, nor - even more - ignored, without compromising the correct interpretation of the evidence. Rigid definitions of philological variants do not really apply, as well as the treatment of linguistic variants can be more complex than the simple application of regularization markup tags, which categorize a 'standard' (not to say 'correct') and a 'deviant' version of a word..$^{49}$

The inadequacy of the traditional philological/stemmatological model to represent in full the textual features of these complex and fluid technical writings has already been pointed out by Ann Hanson, ${ }^{50}$ who advanced an "accretive model of composition" to provide a suitable description of the phenomenon. In David Leith's words,

[t]he textual tradition of compilations of this sort was highly fluid, and we should not conclude that they represent exactly the same text. ${ }^{51}$

and brought it back with the marginal addition of marks indicating clinical histories, traced with dark ink and big letters, in imitation of the original handwriting. Cf. also BONATI 2016b, 63-4, and see below.

48 Cf. ANDORLINI 2003; REGGIANI 2018e and 2018g.

49 Cf. REGGIANI 2018a for further details, and see below.

50 HANSON 1997.

51 D. LEITH, P.OXy. LXXX 5239. 
Digital tools offer now the best solutions to face this challenge, which Isabella Andorlini herself envisioned at the very beginning of the Corpus dei Papiri Greci di Medicina project, a primary focus of which was

la nuova attenzione rivolta alle problematiche editoriali dei testi studiati nella complessità dei rapporti con le fonti rispetto alla tradizione conosciuta. ${ }^{22}$

\section{Envisioning digital critical editions of (medical) papyri}

As I anticipated above, a digital critical edition can be defined as the digital output of a digital philological work. This has a vital outcome in terms of data encoding. Indeed, encoding data involves a digital critical workflow that takes the features of the original texts (and of the printed editions) to adapt them to the digital medium. It requires a thorough philological work, namely a digital philological one, where the digital papyrologist is - to paraphrase Youtie's well-known definition - an artificer of data (in the abovementioned, intellectual meaning of 'data'). Any information taken from the text or from previous editions becomes data (or metadata, i.e. 'data about data'); and even when encoding a print-published edition, one should check carefully the original text to avoid possible inconsistencies and ambiguities inherited by the previous editors, so that the 'liquid' editorial flux goes on.

Moreover,

[e]ncoding fragments is first of all the result of interpreting them, developing a language appropriate for representing every element of their textual features, thus creating meta-information through an accurate and elaborate semantic markup. Editing fragments, therefore, signifies producing meta-editions that are different from printed ones because they consist not only of isolated quotations but also of pointers to the original contexts from which the fragments have been extracted. On a broader level, the goal of a digital edition of fragments is to represent multiple transtextual relationships as they are defined in literary criticism [...]. Designing a digital edition of fragments also means finding digital paradigms and solutions to express information about printed critical editions and their editorial and conventional features. Working on a digital edition means converting traditional tools and resources used by scholars such as canonical references, tables of concordances, and indexes into machine actionable contents. ${ }^{53}$

Therefore, "encoding a text is an interpretive act" ${ }^{54}$ by itself: on the one hand, the encoder (the digital papyrologist) must employ as much criticism and careful discern-

52 ANDORLINI 1997a, 19 (cf. ibid., 21-2)

53 BERTI forthcoming, 2.

54 OWENS 2011. 
ment as possible in order to give the papyrological object its correct digital representation. On the other hand, one must be aware of the fact that the digital medium has different requirements than the printed one. While philology is a way of describing a text to interpret it as a stable source, a phenomenological approach is a way of representing a text in all its components, to describe and understand the underlying semantics. Therefore, when we choose to overcome the inadequacies of a traditional critical edition in favour of the digital multi-space, we must keep in mind the following three fundamental requirements:

- $\quad$ standardization (adapting to the digital medium means to follow its strict rules); ${ }^{55}$

- semantic representation (which may differ from the traditional philological representation, as we will be noticing below);

- usability (in terms of data access, searching and developing options).

Data and metadata can be encoded and used as different, yet interconnected (aligned) information layers. ${ }^{56}$ An XML annotation markup seems to be the best encoding strategy, since it has a consolidated background in the TEI/EpiDoc system that has already been adapted to the papyrological requirements, ${ }^{57}$ providing a standardized and standardizing framework, a semantic annotation, and powerful search options through XPath and XQuery querying languages. ${ }^{58}$ It also allows for any kind of final rendering by means of customizable transformation languages (XSLT). Alignment among layers can be achieved by deploying a CTS URN architecture, which is useful to give unique identifiers to each element and to avoid overlapping hierarchies, especially in linguistic annotation. Annotated layers can be stored in a GIT repository so that open access and collaboration are granted. Some layers already exist in the SoSOL infrastructure (metadata, introduction and commentary, translation, annotated text); more can be envisioned, for example, on the ground of Gerard Genette's textual theory, which describes all possible relations among texts and which has already been claimed as the privileged interlocutor of the complex textual 'dispositive' of papyrus texts. ${ }^{59}$

55 This is indeed a key issue in Digital Papyrology (cf. REGGIANI 2017, passim) as felt by the very first 'fathers' of the papyrological databases (cf. Tomsin 1970, 476).

56 I started envisaging this strategy for the medical corpus in REGGIANI 2015, where I sketched some possible annotation layers (the article stems from a conference paper delivered in 2012, at the very beginnings of the DCGMP project). I revised my argument in REGGIANI 2016a.

57 See the overview discussed by J. Stolk in this volume. In the following pages, I will be referring to the online Leiden+ guidelines at http://papyri.info/docs/leiden_plus.

58 See the query cases mentioned by M. Vierros and G. Celano in this volume.

59 'This 'intertextuality' of the text is what G. Genette would call 'transtextuality'. It is not, perhaps, accidental that postmodern theories on language and 'text' developed more or less at the same time with the spread of the electronic media" (GAGOS 2001, 515 n. 8). Cf. GENETTE 1992. I outline the possible exploitation of Genette's textual theory in relation with the complex textuality of Greek medical papyri in REGGIANI 2018c and 2018e. 
Without any presumption of emulating Herbert C. Youtie, who provided the standard outline of a 'canonical' papyrus edition, ${ }^{60}$ what follows is an attempt of systematizing the extant strategies for encoding a digital papyrus edition, with some suggestions for possible further improvements. The past work on the medical papyri provided the most complex and intriguing cases, but the same recommendations can apply to simpler cases too, as well as to documentary papyri of any sort.

\subsection{Metadata and bibliography}

Papyrus metadata (i.e. contextual information about texts: chronology, provenance, etc.) are currently stored in digital catalogues like the Heidelberger Gesamtverzeichnis (HGV) for the 'documentary' texts, the Leuven Database of Ancient Books (LDAB) and the Mertens-Pack $\left(\mathrm{M}-\mathrm{P}^{3}\right)$ for the 'literary' ones, Trismegistos (TM) for both, and some more specialized ones like the Corpus of Paraliterary Papyri (CPP) or Synallagma. Similarly, digital bibliographical repositories exist, namely the Bibliographie Papyrologique (BP) and Trismegistos bibliographies. ${ }^{61}$ Papyri.info and the DCLP currently include metadata from (respectively) $\mathrm{HGV}+\mathrm{TM}$ and from $\mathrm{LDAB},{ }^{62}$ and point to $\mathrm{BP}$ records as well as to some more resources (e.g. Synallagma). A digital critical edition of medical papyri should of course extend this feature to include the Mertens-Pack ${ }^{3}$ (in its specific Medici et medica section) ${ }^{63}$ and possibly to envision some digital version of Marganne's and Andorlini's printed catalogues of medical papyri. ${ }^{64}$ Contextualization is indeed fundamental: ${ }^{65}$

[1]o studio del manufatto e una sua corretta collocazione cronologica sono informazioni essenziali, che possono interferire con le ipotesi di attribuzione dei contenuti, sia per il rapporto con gli autori noti, sia per un'adeguata impostazione dell'indagine sulle fonti e sugli anelli della tradizione indiretta. La provenienza del reperto papiraceo può, nei casi in cui gli elementi archeologici siano conosciuti, conservare dati preziosi sul contesto in cui inserire le farine di produzione libraria antica, e sui livelli della sua divulgazione in Egitto (centri di diffusione legati alle vie dell'insegnamento e della pratica della disciplina; biblioteche templari, scuole mediche specializzate): l'attenzione ai luoghi accertabili di ritrovamento dei reperti ci permette di delineare il milieu culturale in cui libri di questo genere furono prodotti, o semplicemente letti, da fruitori professionisti e da gente colta con qualche interesse per i temi della salute. ${ }^{66}$

60 YOUTIE 1963, 22-3.

61 On these resources cf. REGGIANI 2017, 39 ff. (catalogues) and 14 ff. (bibliographies) respectively.

62 See R. Ast and H. Essler in this volume.

63 Cf. MARGANNE - MERTENS 1997 and the online resources cited in REGGIANI 2017, 34.

64 MARGANNE 1981a; ANDORLINI 1993.

65 See also M. Vierros' remarks about metadata of documentary papyri in her article for this volume. 66 ANDORLINI 1997a, 21. 
Moreover, the standardizing potential of digital metadata ${ }^{67}$ would be a nice ground to deal with the problem of the definition of textual genres or typologies, and to face the challenge of a categorization, an issue that is well framed - from the medical viewpoint, in the wake of Isabella Andorlini - by Francesca Bertonazzi in the following words.

Classificare i papiri per tipologia non è solo un mero esercizio erudito o, peggio, sterilmente matematico nel senso deteriore del termine: al contrario si configura come un'indagine che può gettare luce sul contesto di composizione e d'uso del testo, e non di rado può agevolare la sua ricostruzione filologica e l'interpretazione esegetica. L'attività non è priva di rischi: un primo problema è sottolineato da quanti mettono in guardia dalla rilevanza statistica dei dati che possono essere desunti dai papiri, che sono inevitabilmente vincolati ai ritrovamenti, al tipo di descrizione fornita dal primo editore, dal tipo di classificazione operata nei primi studi sul testo. Il primo ostacolo, per così dire, è dunque di natura extratestuale, ovvero risiede nella mera quantità di papiri appartenenti a una data tipologia: anche se la maggior parte dei papiri medici afferissero al genere, e.g., del trattato, non per questo si dovrebbe concludere che il trattato fosse il genere più praticato in ambito medico nell'Egitto greco-romano. Un secondo problema, di tipo intratestuale, risiede nella tipologia stessa del documento, che spesso non appartiene in modo netto all'uno o all'altro tipo di testo: "Chi si è occupato anche solo marginalmente della interpretazione di frammenti di papiro a contenuto 'medico', avrà constatato come una delle difficoltà più evidenti è quella del riconoscimento e della definizione del genere testuale, del tipo di opera cui appartennero brani parziali di scritti oggi in larga parte perduti. Una difficoltà dovuta, oltre che alla casualità e alla precarietà del reperto papiraceo, anche alla organizzazione stessa delle opere a contenuto medico, teorico o specialistico che fosse: il riconoscimento di soggetti e termini medici è da solo insufficiente per dirci qualcosa di più preciso sull'impostazione dell'opera originaria, in quanto le singole nozioni tecniche ricorrevano in settori diversi della disciplina, e potevano essere esposte o discusse a livelli di approfondimento e di concettualizzazione anche molto distanti tra loro" [ANDORLINI 1997b, 159].

In quest'ottica, lo studio del corpus offre alcuni casi interessanti di testi a mezzo tra l'una o l'altra tipologia (come P.Oxy. 2.234 + 52.3654,92 tra il catechismo e la raccolta di prescrizioni), oppure di informazioni testuali insufficienti a distinguere con precisione l'appartenenza tipologica (come in P.Oxy. 74.4973: il testo potrebbe riguardare la veterinaria come la fisiognomica), o ancora di testi che pur rientrando nella categoria 'lettera', possono avere natura documentaria (come MPER 13.6 e GMP 2.10, lettere redatte da medici, e P.Mert. 1.12, lettera a un medico) oppure letteraria (P.Oxy. 9.1184 raccoglie varie lettere di Ippocrate).

Un terzo problema, di ordine linguistico, risiede nella terminologia moderna utilizzata per classificare i testi: non di rado si è avvertita la necessità di puntualizzare le varie accezioni di 'etichette linguistiche' attribuite a generi antichi: “[n]el classificare la ricettazione nei papiri ho volutamente differenziato l'uso del termine 'prescrizione' (applicato a medicine complete di indicazione terapeutica, norme estese alla preparazione e all'uso dei rimedi), da quello di 'ricetta' (applicato a formule assai semplificate, limitate all'indicazione dei componenti, attestate anche singolarmente su foglietti di papiro ed ostraca). Con 'prescrizione' e 'ricetta' identifico perciò tipologie leggermente differenti di testi. Definisco col termine 'ricettario' un testo poco elaborato formalmente, che raccoglie ricette o prescrizioni; con 'manuale terapeutico' intendo

67 On standardization in papyrological metadata see REGGIANI 2017, 74-8. 
uno scritto in cui si riconosce un'organizzazione compositiva e formale più complessa, ora prodotto nell'ambito dell'insegnamento della disciplina, ora non diverso dai modelli di 'trattato' terapeutico" [ANDORLINI 1993, 469-70 n. 22]. ${ }^{68}$

\subsection{Introduction and commentary}

The possibility to add a "front matter" and a "line-by-line commentary" is currently allowed by both Papyri.info and the DCLP, though it has been poorly exploited so far. Some documentary samples have been produced in the framework of the born-digital editions described by L. Berkes in this volume; for the DCLP side, see R. Ast and H. Essler ibidem. The DCGMP project utilizes systematically this feature to provide a general introduction to each text and to record the main textual features that cannot be encoded within the text for the moment, namely technical descriptions ${ }^{69}$ (see below for future integration with the Medicalia Online lexical tool) and parallel passages in both other medical papyri and literature (see below for the intertextual layer).

An earlier way of inserting short comment strings (mostly providing information about re-editions of the texts) within the inline markup, through the $<$ note $>$ tag (Leiden+: $/ * \star /$ ), is possible but definitely not exploited nor really recommended (the Leiden+ guidelines warn: "use sparingly”!)

\subsection{Translation}

Translations of the original text in multiple modern languages are currently supported in the existing databases. The DCGMP policy is to produce at least an English translation of each text, but when a scholarly translation in a different language does exist, the preference is granted to that one. As long as translation is a means of interpretation, the possibility to align the original text with its translation(s $)^{70}$ is worth being explored, for instance through the Medicalia Online lexical platform (see below).

\subsection{Materiality}

The physical appearance of the papyrus is of the utmost importance for the papyrologists, who are deeply interested in the material aspect of the fragments. ${ }^{71}$ Size and colour are the first physical features that are indicated in a traditional edition, and

68 BERTONAZZI 2018a, 48-51 (see also pp. $51 \mathrm{ff}$.).

69 In compliance with one of the original goals of the Corpus dei Papiri Greci di Medicina, i.e. the historical-scientific perspective described by ANDORLINI 1997a, 23.

70 On translation alignment cf. e.g. VÉRONIS 2000.

71 See the remarks by R. Ast and H. Essler in this volume. 
since they are not recorded in the metadata catalogues, they should be indicated in the introductory matter (see above) or in new metadata fields. A digital picture could compensate for this, but it is not available for all papyri (see below).

Material features of the writing support are encoded directly in the text itself according to the current standards. As to this point, there are some notabilia that must be stressed because they slightly differ from the traditional editorial practice. Line numbers, for example, are to be indicated for each line (contrarily to what happens in most of the printed editions) in a standardized way (number-dot-space); words that wrap between two lines are indicated with a hyphen after the dot of the second line number, not at the end of the first line. Both Leiden+ procedures may seem rather unconventional to 'traditional' papyrologists, but they are grounded on XML requirements: numbers are related to "line break" tags $(<1 b />)$ that must open each new line of the encoded text; hyphens represent the attribute break="no" in the same $<1 \mathrm{~b} />$ tag, meaning that the new line does not break the word. ${ }^{72}$ In the HTML output things are brought back to the traditional display (line numbers grouped by five, hyphens at the word break).

Writing sides (recto/verso, folios in codices) and multiple fragments are encoded as document divisions (XML $<$ div type="textpart" $>$ ). This tag deploys an $n$ attribute, which expresses the number/letter identifying the fragment/folio (or the letters $r$ / v for recto/verso), and a subtype attribute, defining the type of part: " $\mathrm{frag}$ ment", "folio", but also "column" or "part" if the text is divided into different layouts or sections even within the same writing side. By the way, this is a good way of dealing with texts that are composed by several sub-texts, like e.g. collections of letters or recipes. ${ }^{73}$ Divs can be nested if needed, and each text block is anyway enclosed by an $<a b>$ tag ("anonymous block"). In Leiden+, Divs are introduced by the tag $\angle D=$ followed by the said attributes preceded by dot (e.g. $\angle D=$. r for recto, $<D=$. 1 . fragment for fragment 1 ), the text block by $<=$. Every text tag must be closed at the bottom, paying attention to the correct order (divs are opened before $\langle a b\rangle$ at the beginning, and symmetrically closed at the end).

The most remarkable physical feature of the papyri is fragmentation. This usually results in marginal breaks (printed as rows of dashes at the top and/or at the bottom, closed square bracket on the left, open square brackets on the right) and in-text gaps (represented as square brackets surrounding some indication of the missing text, which may or may not be supplemented). They are currently encoded as in-text markup; however, the digital concept of gap, according to the TEI/EpiDoc canons, is slightly different from the traditional one, and it deserves some comments. Each unsupplied break or lacuna is indeed treated as missing text, and all types of missing

72 See the contribution by G. Celano in this volume for the problems given by non-breaking lines in the digital papyrus texts.

73 An attempt of this can be found at http://litpap.info/dclp/60175 (P.Oxy. IX 1184, Hippocratic letters). 
text are handled with the <gap $>$ XML tag, which is used to encode both lost and illegible portions of text (the latter being usually printed - and are displayed - as series of dots). The $<$ gap $>$ attribute reason distinguishes the two cases ("lost" or "illegible", plus "ellipsis" if the text is missing because left untranscribed by the editor), while the attribute unit specifies if we are dealing with just a number of characters or with entire lines. The extension of the missing text is defined by the attributes extent ("unknown" number of chartacters or lines), quantity (known number of characters or lines), at Least / atMost (approximate range calculation). A precision attribute set to "low" indicates the uncertainty of an extension. Leiden+ syntax developed around the use of dot, after the print conventions of indicating illegible characters by means of dots: a dot followed by a number or a range (and by the indication 1 in when dealing with lines) indicates illegible text; the same, but preceded by the indication lost, marks lost text. If the dot is preceded by vestig, an element $<$ desc $>$ vestiges $</$ desc $>$ is added to the $<$ gap reason="illegible" $>$ tag, in order to encode generic 'traces' (which is indeed the HTML output). Untranscribed text is marked differently (see below), as are supplied gaps, though from the papyrological viewpoint they are actually the same facts as the unsupplied ones (see below).

Unclear characters are another good example of how semantic markup differs from traditional print editions. In the latter, any unclear letter is marked with an underdot, either with the letter on its top (if legible) or not (if illegible). In the digital edition, illegible characters are non-textual portions marked with the <gap reason="illegible"> tag described above, while unclear but legible characters are text portions marked with an $<$ unclear $>$ tag. Leiden+ utilizes the regular Unicode underdot in the latter case, while in the former the dot is recalled with a full stop followed by the number or range of unclear characters. In the HTML display, they become both underdots.

The close relationship between the text and its support is the core focus of the CRMtex project (http://www.cidoc-crm.org/crmtex), which provides tools for managing the study and publication of ancient handwritten documents and may be taken into consideration for developing new strategies in the digital edition of papyrus texts too.

\subsection{Palaeography}

Annotating palaeography is a huge task. Beside a general palaeographical description of the handwriting, which may well be detailed in the front matter, the possibility to mark up each single character is particularly tricky. Apart from its extreme intricacy, such a task should be preceded by a huge effort to standardize palaeographical terms and descriptions, which are notoriously idiosyncratic and inconsistent. Text 
alignment with the digital picture can help: this is precisely the purpose of the Anagnosis project, conducted at Würzburg by Holger Essler, which may eventually come to the automatic recognition of the characters. ${ }^{74}$

Some visual characteristics of the written text are encoded with an appropriate markup that describes the appearance of lines, words or single characters with special display features. Lines that are written perpendicular or inverse with respect to the main body of the text can be encoded with a rend="perpendicular"/"inverse" attribute of the $\langle 1 b />$ tag (in Leiden+, this is obtained by putting the line number in brackets, typing a comma+space instead of dot+space, and then the appropriate attribute value). Similarly, ancient text highlights (taller characters, superscript, subscript, supraline, underline) are tagged with a $<$ hi $>$ element, with a rend attribute specifying the kind of highlighting (standard values: "tall", "superscript", "subscript", "supraline", "supraline-underline"). Leiden+ equivalents are shaped in a graphical appearance that hints to the text display on the papyrus (respectively: $\sim|| x|| \sim \operatorname{tall} ;\left.\right|^{\wedge} x^{\wedge}|; \backslash| x \mid /{ }^{-}{ }^{-}{ }^{-} ;=x=$ ). It must be noted that currently the use of this markup is deprecated when the highlighting describes an abbreviation (see below). A text written inside a box is encoded with a milestone element $\left(<\right.$ milestone rend="box" unit="undefined"/>; Leiden+: \#\#\#). ${ }^{75}$

Another palaeographical feature that can be encoded with the current markup is the handshift (<handShift new="m2"/>; Leiden+: \$m2; displayed as (hand 2)); for the use of this tag see also Marja Vierros' chapter in the present volume (which - by the way - contains also an interesting discussion about palaeographical metadata).

\subsection{Text}

At the core of the papyrus fragment, text as a linguistic fact deserves the highest and deepest attention, for both the peculiarities of the language of the papyri in general and the specific relevance of technical language in small corpora like the medical writings. ${ }^{76}$ Digital annotation is a fundamental practice in the linguistic study of a corpus of texts: ${ }^{77}$ it allows to describe, record, interpret and analyse linguistic information at several levels, in which each layer corresponds to a particular category of

74 See below and the Anagnosis section of the chapter by R. Ast and H. Essler in this volume; cf. REGGIANI 2017, $151 \mathrm{ff}$.

75 Cf. CORAZZA 2018a; see below for 'milestones'.

76 The lexical and linguistic study has always been a primary purpose of the Corpus dei Papiri Greci di Medicina: cf. ANDORLINI 1997a, 24.

77 On the definition of linguistic corpus cf. SINCLAIR 1996; in general on corpus linguistics cf. LÜDELING - KYTÖ 2008-09; LÜDELING 2011; and see M. Vierros and I. Bonati in this volume. On the theoretical and practical correctness of treating Greek medical papyri as a proper textual corpus I think 
relevant information. ${ }^{78}$ Multiple levels of linguistic annotation of papyrological relevance can be outlined. ${ }^{79}$

\subsubsection{Part-of-speech annotation}

The basic annotation layer, related to the analysis of the parts of speech - also known as treebank because it is usually represented with a tree graph -, would allow to conduct an extensive lexical, phraseological-formulaic and syntactic analysis on the corpus, aimed also (but not only) at discovering styles and writing strategies specific of the medical texts, both literary and documentary: think only of the possibility to investigate formulaic uses and writing skills, ${ }^{80}$ to find out influences or interpolations between authors, or the presence of literary echoes in technical or documentary texts. ${ }^{81}$ The entire technical textual strategy deployed by medical authors ${ }^{82}$ could be studied in this way. Analysing in depth and comprehending the syntactic structure of texts would allow also to solve problems of interpretation and attribution, ${ }^{83}$ or even

there must be no doubt. A linguistic corpus is usually intended as a selection of sample texts representative enough of a language, and though the medical papyri at our disposal come from a random and incomplete selection, they can be considered as the entire reference population rather than as a sample of a larger group, so that linguistic annotation seems to me absolutely feasible.

78 Cf. REgGiani 2017, 178 ff., and M. Vierros in this volume.

79 Cf. REgGIANi 2015 and 2016a; BERTONAZZI 2018b.

80 Cf. MaRAVEla - REgGiani 2018. RouEd-CunlifFe 2014 described how digital encoding can prove useful for the analysis of grammar patterns of an ancient textual corpus (the Vindolanda tablets). A seminal project on annotating a corpus of private letters on papyrus, conducted by S. Porter and M. O’Donnell, has produced a number of valuable observations about modes and tenors of discourse, structures of information, semantic patterns, and so on (PORTER - O'DONNELL 2010).

81 "[L]a possibilità di identificare alcuni papiri con trattazioni di un autore tramandato solo indirettamente inserisce tasselli nuovi nella complessa stratificazione della trasmissione indiretta, soprattutto quando sono i papiri i soli testimoni diretti di autori tramandatici per excerpta e citazioni (Apollonius Mys, Heras, Heliodorus, Herodotus Medicus)” (ANDORLINI 1997a, 22).

82 ANDORLINI 2006 pinpointed the existence of an expressive strategy of medical technical texts: “L'osservazione di tali fenomeni, e del loro riproporsi costantemente nella tradizione dei testi medici greci su papiro, permette di riconoscere diverse fasi e livelli in cui il sapere tecnico contenuto nella ricetta medica veniva materialmente veicolato al lettore/consumatore attraverso moduli espresssivi e dispositivi tecnici, visivi, fisici, che formano una sorta di koinè, un tutt'uno tra lingua tecnica e scrittura speciale dei testi. Di qui la suggestione di rintracciare una specie di 'gergo' nei connotati di quel particolare linguaggio criptico, grafico ed espressivo, che comunica all'interno di una determinata categoria professionale: il medico, gli altri medici (i colleghi), il farmacista, il commerciante di farmaci, il paziente. Si tratta di modi speciali di usare parole e segni attraverso i quali le competenze medico-terapeutiche tendono a specializzarsi all'interno di una corporazione di addetti alla professione medica” (p. 153).

83 "L'analisi sintattica attraverso l'annotazione in un cosiddetto 'treebank' potrebbe mostrare più chiaramente la struttura del testo e facilitare il confronto tra il testo veicolato dal papiro e la tradizione 
only to understand the exact meaning of a text (let us consider for instance the case of schematic prescriptions - e.g. P.Oxy. VIII 1088, http://litpap.info/dclp/63118 where implicit verbs and asyndetic syntax would have to be made explicit).

In the field of classical philology such linguistic analyses are now at a very advanced level, but papyrology too has made important progress, with the project $S e$ matia, aimed at facilitating the linguistic tagging of the documentary papyri encoded in Papyri.info and described by Marja Vierros in this volume. Another possible way to linguistic annotation of the papyri is explored by Giuseppe Celano in the present book as well. The literary side has been unfolded by the Grammatically Annotated Philodemus project, conducted by Daniel Riaño Rufilanchas and Holger Essler (Würzburg) and aimed at deeply annotating the Greek philosophical papyri from Herculaneum on morphological, grammatical, semantic, stylistic layers. ${ }^{84}$ Fragmentation is of course an issue when one decides to perform linguistic analysis: phrases, sentences, words are broken and it is not rarely difficult to understand the syntax, not to say to tokenize the words. ${ }^{85}$ These are problems that digital tools must unavoidably face, and which an infrastructure based on multiple interconnected layers may feasibly overcome.

manoscritta, soprattutto nel caso di papiri per cui si sospetti una possibile paternità" (BERTONAZZI 2018a, 74). The case of surgical author Heliodorus is paradigmatic: "l'analisi del lessico tecnico dei papiri chirurgici ha portato a individuare paralleli testuali tra testo tramandato su papiro e tradizione manoscritta, talvolta significativamente stringenti come nel caso di P.Strasb. inv. 1187 e diversi passi di Eliodoro ap. Oribasio. Alcuni altri papiri (P.Lond.Lit. 166, P.Gen. inv. 111, P.Fuad.Univ. 1, P.Ryl. 3.529), come già notato dagli studiosi, sono caratterizzati da una forte presenza di 'lessico eliodoreo' e da alcune peculiarità proprie del modus operandi del chirurgo, come la predilezione di interventi chirurgici che siano il più sicuri possibili per il paziente, nonché del modus scribendi, come il ricorso frequente alla prima persona - singolare o plurale -, la definizione con esattezza delle posizioni 'topografiche' della parte operata (dentro, fuori, sopra, sotto), e una sostanziale semplicità delle strutture sintattiche usate. Ad oggi, i tentativi di attribuire i papiri citati alla paternità di Eliodoro si sono basati quasi esclusivamente su criteri lessicali nel confronto tra il testo tramandato su papiro e sui capitoli di Oribasio che portano la titolatura 'da Eliodoro'. Una nuova possibile strada offerta dalle nuove tecnologie della papirologia digitale è quella costituita dall'annotazione sintattica dei testi: un'analisi più accurata non solo del lessico, che come è noto è la parte più 'volatile' della lingua, ma delle strutture morfologiche e sintattiche dei passi del compilatore tardo in sinossi con i testi dei papiri, sia pure nella limitatezza delle pericopi testuali preservate, potrebbe gettare nuova luce anche su questo aspetto tra i più incerti quanto stimolanti della ricerca” (BERTONAZZI 2018a, 242-3). Marja Vierros has recently presented at the workshop "Act of the Scribe: Interfaces Between Scribal Work and Language Use" (Athens, April 6-8, 2017) some preliminary remarks on Applying Modern Authorship Attribution Methods to Papyri and Ostraca (abstract at http://blogs.helsinki.fi/actofscribe/workshop): cf. REGGIANI 2017, 185.

84 Cf. REGGIANI 2017, 181; R. Ast and H. Essler in this volume.

85 Cf. RIAÑo RufILANCHAS 2014, 160-1; ESSLER - RIAÑo RuFILANCHAS 2016, 498; and the observations by R. Ast and H. Essler, M. Vierros, and G. Celano in the present volume. 


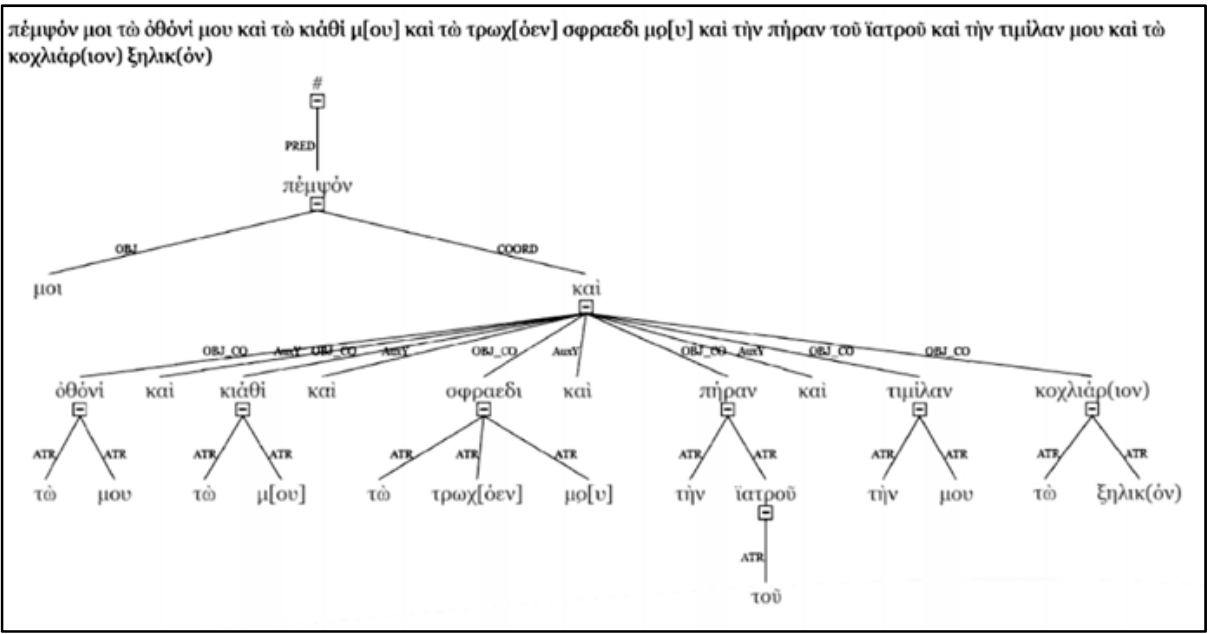

Fig. 3: Sample treebanking of GMP II 10, medical letter (from REGGIANI 2015).

\subsubsection{Lemmatization}

An annotation layer of lemmatization, that is the reduction of a declined or conjugated word to its original lemma, would prove essential in defining and analysing a specialised technical vocabulary like the one employed in the medical papyri, which has always been a relevant research focus of Isabella Andorlini's concept of the medical corpus. ${ }^{86}$ Such a sort of layer would represent an important bridge to connect the textual database to the related project Medicalia Online, consisting in an extensive lexical reference platform for ancient medical technical terms, as described by Isabella Bonati in this volume. ${ }^{87}$ Systematic links to the lexical records (and the other way around) could contribute to create a dynamic lexicon ${ }^{88}$ of medical technical terms in the Greek papyri. In addition, as Joanne Stolk observes in this volume, the possible deployment of a lemmatization layer would help encoding linguistic variation more properly, while encoding lexical information would be helpful for the creation of word reference indices.

86 Cf. ANDORLini 1997a, 24. For more recent works on this topic see BonATI 2016a, 2017, 2018a, 2018c, and BERTONAZZI 2018a. For a parallel exploitation of digital encoding for the development of vocabulary analysis, cf. RouED-CUNLIFFE 2014 apropos of the Vindolanda corpus.

87 Cf. also BONATI 2018b and 2018d. On the connection between digital editions and Medicalia Online cf. also BERTONAZZI 2018a, 43-8 and 73-4, and 2018b.

88 On "the interdependence of lexica and new editions" cf. ESSLER - RIAÑO RUFILANCHAS 2016, 492. ROUED-CUNLIFFE 2014 speaks of “integrated indexing”. 


\title{
4.6.3 Abbreviations
}

Abbreviations are another striking point. Medical writings (prescriptions above all, but not only) make a particularly extensive use of abbreviated words, ${ }^{89}$ developing a proper "graphical-expressive jargon"; 90 given their technical nature, it would be extremely useful to investigate their use, e.g. whether there is any underlying pattern. As to now, abbreviations are to be encoded in the same way as the documentary papyri, that is according to the type of expansion - resolved or unresolved, distinguished on the ground of the XML syntax. Resolved abbreviations are encoded as "expansions", with the <expan> tag enclosing the text spelled out and the $<e x>$ tag enclosing the text abbreviated (Leiden+: double set of brackets, one enclosing the whole word and the other one enclosing the expanded abbreviation); unresolved abbreviations are encoded as "abbreviations", enclosed by the $<$ abbr $>$ tag (Leiden+: $(|x|))$. Any attempt to encode the type of abbreviation (e.g. by raised letter or by overline) is currently deprecated. ${ }^{91}$ I strongly hope that in the future this level of annotation may be taken into consideration, since abbreviating strategies are relevant for the correct transcription and interpretation of texts, as in P.Strasb. inv. 1187 (http://litpap.info/dclp/59968), which

\begin{abstract}
exhibits two cases of allegedly abbreviated words that have been object of interpretative discussion. At 11.11 and 14 two $v$ overlined with a horizontal stroke (belonging to a plural genitive and a nominative respectively: $-\omega^{-}$) are clearly legible; these strokes are abbreviation marks according to FAUSTI 1989, 158, contra MARGANNE 1998, 68, following ed.pr. for the latter, which supplies the $v$ as omitted by the scribe, in angle brackets. The presence of the overline strongly suggests that we are indeed dealing with abbreviated words: therefore, though relying by rule on the more recent edition, [for the digital edition] it has been chosen to follow the editio altera, marking the abbreviations according to the current Leiden+ conventions, though preserving the reading of the editio tertia in an |ed| tag. ${ }^{92}$
\end{abstract}

In the described case, a correct understanding of the abbreviation mark proves essential in the text editing and encoding. Moreover, special ways of expressing combinations of characters or even entire words cannot be encoded but in the standard, simplified way: for example, to limit ourselves to the cases of P.Ant. III 127 (http://litpap.info/dclp/65340) mentioned by CoRAzZA 2018b, the sinusoid for $\alpha$ s and the peculiar sign $\cdot / / \cdot$ for $\varepsilon$ เol, which must be encoded as whichever symbol <expan $>\langle e x\rangle \varepsilon\llcorner\sigma \iota</$ ex $\rangle</$ expan $>$ (Leiden+: $((\varepsilon\llcorner\sigma \iota)))$, losing interesting pieces of information.

89 Cf. e.g. the case of the Antinoupolis papyri described in CORAZZA 2018b.

90 Cf. ANDORLINI 2006.

91 Cf. REGGIANI 2018b, and see L. Berkes in this volume. As he notes, text-image alignment could be a good compromise: but searching for the different abbreviation types would not be possible as well. 92 BERTONAZZI 2018b; cf. BERTONAZZI 2018a, 67. 
A tentative proposal, based on a preliminary survey conducted on the different abbreviation typologies in the Greek medical papyri and on the TEI/EpiDoc XML guidelines, envisions the following possible instances (apart from 'traditional', 'simple’ abbreviations): ${ }^{93}$

- Supralinear abbreviations (e.g. $\chi \alpha \lambda \kappa \alpha^{\prime} v^{\theta}(\mathrm{ov})$ : PSI X 1180a iii,12). The superscripted letter may be tagged as any normal superscripted letter $(<\mathrm{hi}$ rend="superscript" $>$ tag); such a combination is already possible and correct in the current Leiden+ syntax, yet deprecated by the official guidelines. XML: <expan> $x \alpha \lambda$ kó $v<$ hi rend="superscript" $>\theta</$ hi $><e x>$ ou $</$ ex $>$

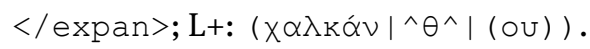

- Abbreviations by stroke (horizontal: e.g. $\tau \tilde{\omega}^{-}(v)$, P.Mich. XVII 758 H verso,2;

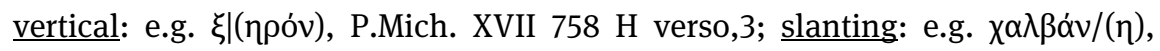

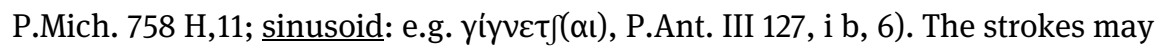
be encoded through the EpiDoc <am> tag ("abbreviation mark") ${ }^{94}$ and further defined as non-alphabetic glyphs (see below) as follows: <expan $\rangle\langle$ abbr $\rangle \tau \tilde{\omega}$ $<a m><g$ type="horizontal-stroke"/> </am $\rangle \quad\langle/$ abbr $\rangle\langle e x\rangle v$ $\langle/$ ex $\rangle\langle/$ expan $\rangle=(\tau \tilde{\omega}$ *horizontal-stroke* $(\nu)) ;\langle$ expan $\rangle\langle$ abbr $\rangle$ $\xi<$ am $><$ g type="vertical-stroke" / $></$ am $></$ abbr $><$ ex $>$ nóv $</$ ex $>$ $<$ expan $>=(\xi *$ vertical-stroke* (npóv)) ; <expan> <abbr $>$ $x \alpha \lambda \beta \alpha ́ v<$ am $><$ g type="slanting-stroke" $/></$ am $></$ abbr $><e x>n$ $</$ ex $></$ expan $>\quad=\left(x \alpha \lambda \beta \alpha ́ v^{*}\right.$ slanting-stroke* $\left.(\eta)\right) ;<\operatorname{expan}>$ $<$ abbr $>$ Y $\{v \varepsilon \tau<$ am $><$ g type="sinusoid" $/></$ am $></$ abbr $><$ ex $>\alpha$ L $</$ ex $>$ $</ \operatorname{expan}>=\left(\gamma i \gamma \vee \varepsilon \tau{ }^{*}\right.$ sinusoid* $\left.(\alpha L)\right)$. Note that such combinations are correct in the current Leiden+ syntax, but the strokes need to be rendered properly in the HTML output; moreover, the <am> tag is not supported by the platform.

- Discontinuous abbreviations (e.g. $\mu(\varepsilon) \tau(\dot{\alpha})$ : MPER n.s. XIII 9, 1). This type of abbreviation is already normally working in the SoSOL environment. <expan $>\mu<e x>\varepsilon</$ ex $>\tau<e x>\alpha</$ ex $></$ expan $>=(\mu(\varepsilon) \tau(\dot{\alpha}))$.

- $\quad$ Abbreviations by monogram (e.g. $\sigma \chi \mathrm{l}(\sigma \tau o \tilde{v}) ; \pi \rho($ ó $) ; \chi \rho(\tilde{\omega})) .{ }^{95}$ This type exploits the way in which monograms are marked up in EpiDoc and Leiden+, ${ }^{96}$ i.e. a ' $\mathrm{g}$ type' with indication of the letters that are interwoven to form the monogram. $<$ expan $><$ abbr $><$ am $><$ g type="monogram" $>\sigma x \iota</ g\rangle</ a m></ a b b r\rangle$

93 In general, on abbreviations in papyri see e.g. CLARYSSE 1990, DEGNI 1999, and GoNIS 2009; with special regards to documentary texts, BELL 1953 and BLANCHARD 1974; for literary papyri, MCNAMEE 1981 and 1985. A typological work on the abbreviations in medical papyri has been preliminarily conducted by L. Iori and M. Centenari in the framework of the Corpus of the Greek Medical Papyri Online project (cf. http://www.papirologia.unipr.it/eventi/GDS/2010/centenari-iori.html).

94 Cf. http://www.stoa.org/epidoc/gl/latest/trans-abbrevmark.html.

95 On the relevance of the monogram $\chi \rho(\tilde{\varphi})$ see ANDORLINI 2018.

96 Cf. http://papyri.info/docs/leiden_plus s.v. "Non-alphabetical character with symbol". 


\begin{abstract}
$<$ ex $>\sigma X\llcorner\sigma \tau \circ \tilde{U}</$ ex $></$ expan $>=($ (*monogram, $\sigma X\llcorner * \sigma X\llcorner\sigma \tau O \tilde{U})) \quad ;<\operatorname{expan}>$ $<$ abbr $><$ am $><$ type="monogram" $>\Pi \rho</ g></ a m></ a b b r><e x>$ прó $\varsigma</$ ex $></$ expan $>=$ ( (*monogram, пр*прó $\varsigma)$ ) ; <expan> <abbr $>$

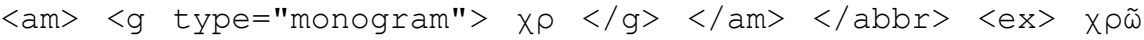
$</$ ex $></$ expan $>=\left(\left({ }^{*}\right.\right.$ monogram, $\left.\left.\chi \rho^{*} \chi \rho \tilde{\omega}\right)\right)$. This may apply to some symbols for units of measure too, e.g. $\lambda i(\tau \rho \alpha), o(\hat{v}) y\left(\chi^{i} \alpha\right)$, etc., which may make easier a systematic study of quantities and dosages in the ingredient use. Number digits and values can be easily encoded in the current way (XML: <num value="16" $>\llcorner\varsigma</$ num $>$; Leiden $+:<\# \iota \varsigma=16 \#>)$.
\end{abstract}

\title{
4.6.4 Linguistic variation
}

The topic of linguistic variation is the most intriguing and difficult to handle. As noted above, traditional critical editions tend to overcome any fluctuation in favour of a reconstructed text, while fluctuations are actually fundamental for the phenomenology of the written text. Linguistic variation in the papyri has already been extensively investigated by Joanne Stolk, who resumes her thoughts from the digital perspective in this same volume. I would like just to focus on some relevant points, to introduce the problem of linguistic variation in the medical papyri. The current markup of what I call textual fluctuations - handled by the $\langle$ choice $\rangle$ tag, "indicating that [the readings] are two editorial versions of the same span of text, and should be read as alternatives, not shown side by side" 97 - distinguishes between "corrections" of outright, well recognizable scribal mistakes (<corr $\rangle$ tag marking the correction, $\langle$ sic $\rangle$ tag marking the original reading; Leiden $+:<$ : correction $|\operatorname{cor} r|$ original : $>$ ) and "regularizations" of phonetic misspellings ( $<r e g>$ tag marking the regularization, <orig > tag marking the original reading; Leiden+: $<$ : regularization $\mid$ reg $\mid$ original: $>) .{ }^{98}$ Though the treatment of 'regularizations' has been improved during the history of the

$97 \mathrm{http} / / /$ www.stoa.org/epidoc/gl/latest/trans-regularization.html: "It is most common to mark a regularization of this kind at the level of the whole word, rather than of individual characters affected [...]. This will make it easier to generate an apparatus reading for the regularized form (or the original form, depending on which you want to privilege), but it may also be impossible to identify individual affected characters in a dialect spelling or grammatical form. On the other hand, tagging the individual characters might make it easier to index or search for specific features, such as the iotacism of $\mathrm{t}$ and عı". See J. Stolk's observation (in this volume) that apparatus regularizations/corrections work as textual equivalents and not 'better' substitutes of the original text.

98 For some case studies cf. BERTONAZZI 2018a, 63-4. 
papyrological databases, by moving the display of the original spelling from the apparatus to the main text and vice versa, ${ }^{99}$ showing a stronger care for the phenomenology of the papyrus text, and though the meaning of the $\langle$ choice $>$ tag points to alternative encodings of the same text portion, the fact is that we are still dealing with a differentiation between a form that is considered as 'standard' or 'regular' and a

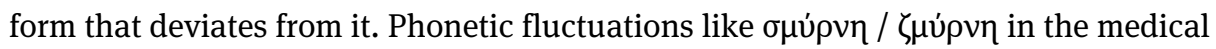
papyri $^{100}$ (but see also some relevant cases in the documentary papyri, like $\chi u ̛ \tau \rho \alpha$ /

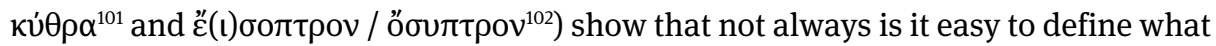
is the 'conventional' spelling and what is the 'deviation', so that a layer capable to align the 'variants' to each other, word by word, rather than categorizing them in a sort of hierarchy, may be much welcome. ${ }^{103}$

Diachronic and synchronic fluctuations - depending on the evolutions and transformations of Hellenistic Greek language and on the rise of personal or geographical substandards ${ }^{104}$ - do occur in the medical papyri, but their existence not rarely points

99 In the earlier Duke Databank of Documentary Papyri, "the conventional koine form is given first, followed by numbered braces enclosing the scribe's form or the edition's misprint: e.g., obvo $\mu \alpha$ $\{4 \omega v o \mu \alpha\} 4$ shows that the scribe has misspelled övo $\mu \alpha$, vंrè $\{5 v \pi \alpha \rho\} 5$ that he wrote epsilon over al-

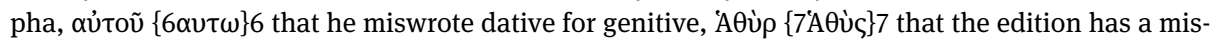
print for "AӨìp" (WILLIS 1984, 169-70); cf. REGGIANI 2017, 216. This slight prominence given to the 'standard' form was retained in the first stages of Papyri.info, where it was included in the main digital text, whereas the original form as written by the scribe - marked with $|r e g|,|\operatorname{corr}|$ or the former | orth | tag (cf. REGGIANI 2017, 236 n. 119) - was displayed in the apparatus. As of September 2011, the two elements in the $\mid$ reg $\mid$ tag have been swapped with each other (cf. http://digitalpapyrology.blogspot.it/2011/09/just-posted-to-papylist-dear-colleagues.html). This required a huge effort, because the ancient reading was originally transcribed diplomatically without spirits and accents, but its inclusion in the text made it necessary to add them (cf. REGGIANI 2017, 224).

100 "Nei papiri è scritto quasi regolarmente $\zeta \mu$-" (ANDORLINI 1981, 61 n. 54), which conversely should be a 'deviating' spelling of 'regular' $\sigma \mu u$ pv (cf. GIGNAC 1976, 121-2).

101 Cf. BONATI 2015.

102 On this peculiar double fluctuation cf. BONATI - REGGIANI 2018.

103 Cf. e.g. BOSCHETTI 2007 apropos of philological variant alignment; further discussion in REGGIANI 2018a. The current platform also allows for handling language shifts, i.e. the markup of a language or script different than the main document's default. This is rendered with the tag <foreign> and the $\mathrm{xml}$ : lang attribute, the value of which may be grc for Greek words in a Latin text, la for Latin words in a Greek text, grc-Latn for Greek words in Latin characters, la-Grek for Latin words in Greek characters, and so on. In Leiden+ it is marked $\sim|x| \sim \operatorname{grc}$ and the like. If characters or lines in a different language or script are omitted by the editor, this is indicated with the <gap reason="ellipsis" > tag (see above) including a <desc $>$ tag filled with the appropriate language (e.g. Coptic, Demotic; Leiden+: (Lang: Coptic 1 line) etc.). It is also possible to mark up crosslanguage equivalencies, for example giving the Greek correspondent of a Coptic term. For this task, the current system exploits the 'regularization' tag by adding an $\mathrm{xml}:$ lang attribute, e.g. <choice $>$ <reg xml:lang="grc"> apokos </reg> <orig> Арגk</orig> </choice> (Leiden+:

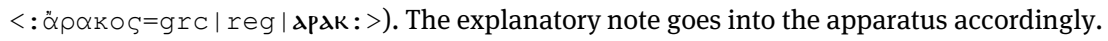

104 Cf. REGGIANI 2018a and 2018c. 
to deeper levels of textuality, with reference to ancient literacy and intertextual relations (see below), and therefore deserve a very peculiar attention. For example, in P.Aberd. 124, i = GMP I 1, i (II cent. AD, http://litpap.info/dclp/63334), a papyrus fragment preserving chapter 37 of Hippocrates' treatise De fracturis, at 1. 14, where all the codices (and the editions) have the 'regular' Ionic form $\pi$ ńxعos, the papyrus shows

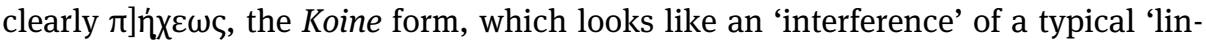
guistic variation' pertaining to the language of the documentary papyri, where it would be the standard form. ${ }^{105}$ Perhaps even more significant are the following cases. P.Oslo inv. 1576, a fragment of a catechism dealing with tumour-like diseases, ${ }^{106}$ partly overlaps with the text of P.Oxy. LXXX 5239 (both II-III cent. AD). The latter is more likely a 'treatise' than a questionnaire, as its editor David Leith notes (see below for this distinction), and the difference may be perceived from the lack of eistheseis in its questions. The scarceness of the surviving portions of text makes it hard to say whether the questionnaire derives from the treatise or they are two different outcomes of a same ascendant (see below for intertextual relations). As far as the extant parallel text is concerned, the wordings diverge from each other only for one variant:

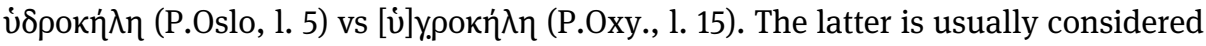
as a minority variant (LSJ, quoting Poll. IV 203) of the former, used e.g. by Ps.Gal. Def.med. 424 = XIX 447,12-13 K., but it is in fact attested three times among the medical writers. ${ }^{107}$ Are we facing a trivialization in the Oslo papyrus, or a simple phonetic variant in the Oxyrhynchus papyrus, or just two different traditions bearing the same degree of 'correctness', attesting to a fluid notion of technical language? Moreover, in the following line of the Oslo papyrus (not paralleled by its Oxyrhynchus counterpart

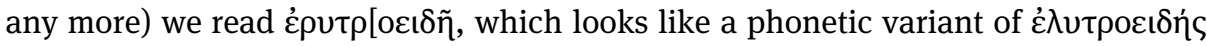
"lid-like", "cover-like” (attribute of one of the membranes enveloping the scrotum). Rho for lambda is indeed a very frequent phonetic exchange in the language of the Greek papyri, ${ }^{108}$ but the same variation is to be found among the manuscripts preserving Ps.Galen's Introductio seu Medicus, containing a descriptive passage (XIV 719,5$10 \mathrm{~K}$.$) of the same anatomical part. { }^{109} \mathrm{~A}$ similar case is offered by P.Coll.Youtie I $4 \mathrm{~V}$

105A comparable case is toĩ (and the following forms supplied accordingly) in P.Fay. 204,9 (http://litpap.info/dclp/60181) vs Ionic toĩoı of the rest of the tradition of Hippocratic aphorisms.

106 MARAVELA - LEITH 2007. The papyrus will be republished in the forthcoming third volume of the Papyri Osloenses. I am most grateful to Anastasia Maravela for sharing her drafts of the new edition and for discussing with me some textual and linguistic details.

107 Orib. Syn.Eust. III 28, 6 and 9 = CMG VI 3, p. 75, 15-16 and 21 Raeder; Steph. In Hp. Progn. II $1=$

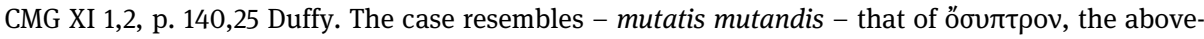

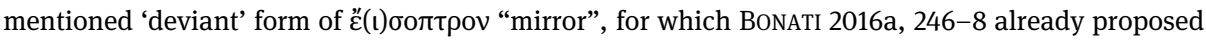
the rank of substandard.

108 Cf. GignaC 1976, 105.

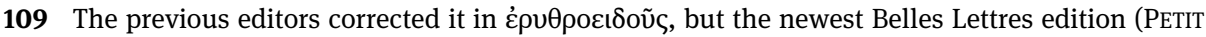

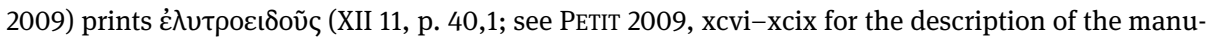
script tradition). Quite interestingly, the author of the treatise came possibly from Egypt (cf. PETIT 
(http://www.litpap.info/dclp/64118), a collection of prescriptions dated around the III cent. AD, in which $\varphi \lambda$ oṽ $\varsigma$ at 1.8 ("reed bed") could be a spelling variant of $\varphi \lambda$ otó ("bark") just as $\varphi \lambda$ otóv in Dsc. III 147 has a variant reading $\varphi \lambda$ oũv. ${ }^{110}$ In a completely different type of text, P.Oxy. XIX 2221r + P.Köln V 206r (http://litpap.info/dclp/61916), a I-century AD commentary to Nicander's Theriaka attesting interesting textual vari-

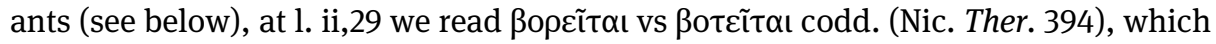
looks like the genuine form; the reading of the papyrus is a phonetic variant of the

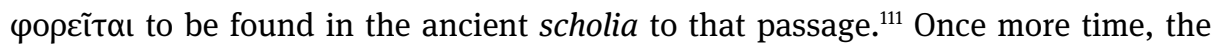
impression is that we are facing a peculiar intersection of multiple literacies, emerging at the phonetic level but implying deeper meanings that cannot be flattened in a traditional apparatus.

Even seemingly outright syntactic 'mistakes', in such a technical corpus as the medical papyri, can conceal deeper levels of meaning: an established prescriptive

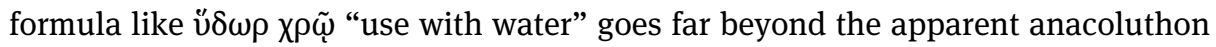

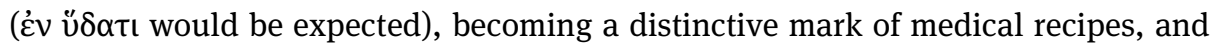
must be treated accordingly. ${ }^{112}$

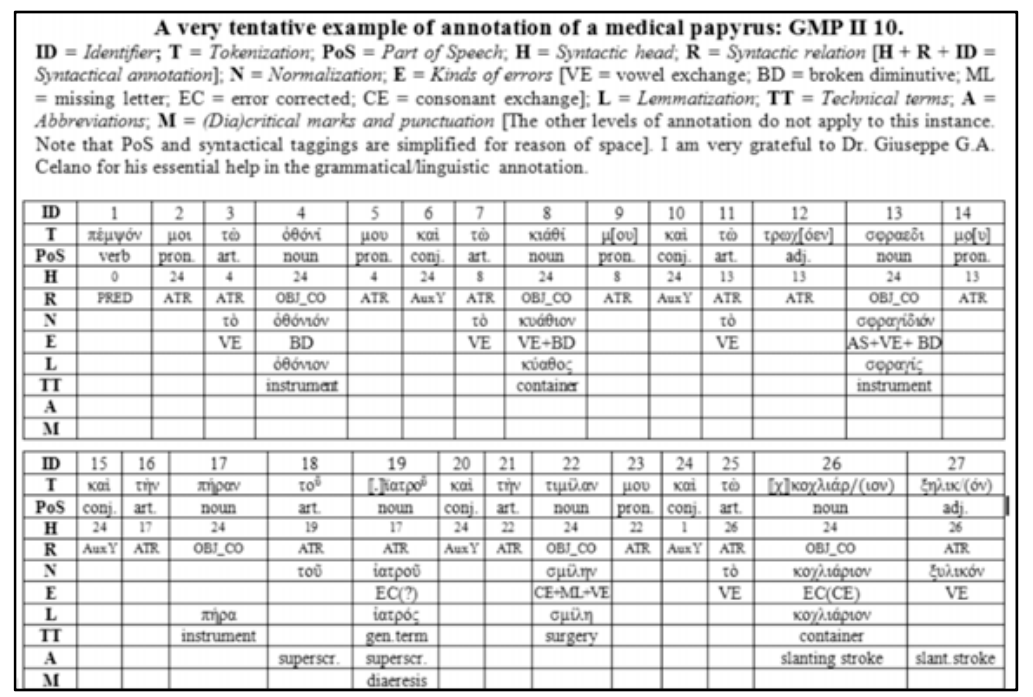

Fig. 4: a former attempt to outline some annotation layers for Greek medical papyri (REGGIANI 2015).

2009, 1-li), which suggests that the phonetic variation could have worked both ways. I discuss this and the preceding case in REGGIANI 2018a and 2018e.

110 Cf. T.T. RENNER, ad loc.

111 The same phonetic exchange $\beta / \varphi$ occurs elsewhere in the papyrus: see $\dot{\alpha} \mu \varphi$ í $\sigma \alpha$ av $\alpha$ for

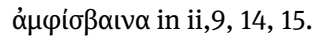

112 Cf. ANDORLINI 2006, 163, and 2018; REGGIANI 2018a. 


\subsubsection{Transtextuality}

As we saw, quite often linguistic phenomena may be clues to broader cultural facts. The complexity of textual phenomena in the Greek medical papyri (but not only!) can be effectively described through the concept of transtextuality as investigated by Gérard Genette since the Eighties. Transtextuality defines all the various possible relationships among texts ("all that sets the text in relationship, whether obvious or concealed, with other texts") ${ }^{113}$ and encompasses several subcategories, ${ }^{114}$ on which I will base the description of the next layers.

\subsection{Paratext}

Paratextuality is defined as the relation between one text and what surrounds the main body of the text: in Genette's theory, paratext is mainly composed of titles and headings, but we may add any other graphical device that comes along the text itself, including punctuation, which is not a common feature in papyrus texts and therefore deserves special treatment. ${ }^{115}$

In a writing system based on scriptio continua (i.e. not separating letters into words), punctuation is a way of facilitating the reading by separating words or groups of words. Single, double, triple dots occur irregularly with this function; in TEI/EpiDoc they are encoded as "non-alphabetical glyphs" with the tag $\langle g\rangle$ and the attribute type defining their nature (e.g. $<$ g type="middot"/>, <g type="dipunct" $/>$, $<g$ type="tripunct" / >). In Leiden+, the so-called 'g-types' are encoded by typing the attribute name between two asterisks. This is usually how other lectional signs (apostrophe, diastole, stigmai) and all graphical devices (check marks, deletion marks, parentheses, line fillers, strokes) work in this markup: a full list of what is supported by Papyri.info can be found at http://147.142.225.252/paptrac/wiki/gtypes, while new signs are being developed specifically for the DCLP. ${ }^{116}$

A small set of other signs, separating not letters or words but entire text sections, is encoded as 'milestones': ${ }^{117}$ this is the case with paragraphos (<milestone

113 GenETte 1992, 83, then GENETTE 1997, 1.

114 Cf. GenetTE 1992, 83-4, later developed in GenETTE 1997, 1-7.

115 On punctuation in the papyri cf. the overviews by TURNER 1987, 7-10, and CRIBIORE 1996, 81-3. For specific issues cf. DEL MASTRO 2017 (Herculaneum papyri) and FUNARI 2017 (historical fragments). For the particular care for paratext in the digital editions of literary papyri see the notes by R. Ast and H. Essler in this volume.

116 On ancient punctuation and encoding/annotating issues see the article by G. Celano in this volume. On filling marks in the papyri cf. BARBIS LUPI 1992. On diacritical and lectional signs see now also NODAR DOMÍNGUEZ 2017 and MCNAMEE 2017.

117 Cf. http://www.stoa.org/epidoc/gl/latest/trans-textpart.html for the difference between Divs (structural text parts) and milestones (non-structural text parts). A possible issue is that in fact e.g. 
rend="paragraphos" unit="undefined"/>), which has been supported by Papyri.info since the beginnings, and with the new additions developed for DCLP, i.e. koronis (<milestone rend="coronis" unit="undefined"/>) and forked paragraphos a.k.a. diple obelismene (<milestone rend="diple-obelismene" unit="undefined" / >). ${ }^{118}$ They are all placed between any two lines of text and in Leiden+ are encoded as rows of four typographical characters depending on the sign (four hyphens for paragraphos: ----, four equals for koronis: ====; four combinations of dash + angle bracket for diple obelismene: $->->->->)$.

The diple has been categorized as 'milestone' as well ( $<$ mi lestone rend="diple" unit="undefined"/>, Leiden+: >>>>), though this may create some issues, since diplai are frequently used in the margins to highlight a specific section, phrase or word, and encoding them as milestones would not be semantically correct. ${ }^{119}$ A similar issue may arise when the paragraphos is used between two lines to separate two sections of a text but the logical division occurs within the preceding or the following line, as in PSI VI $718=$ SB XXVI 16458 (IV AD, http://litpap.info/dclp/64564). This sheet, likely cut off from a small parchment notebook, contains part of a collection of prescriptions separated from each other by inline filling marks and interlinear paragraphoi. The last recipe starts in 1.12 , following the end of the preceding one and after a separator mark, though the paragraphos is traced between 11.12 and 13 .

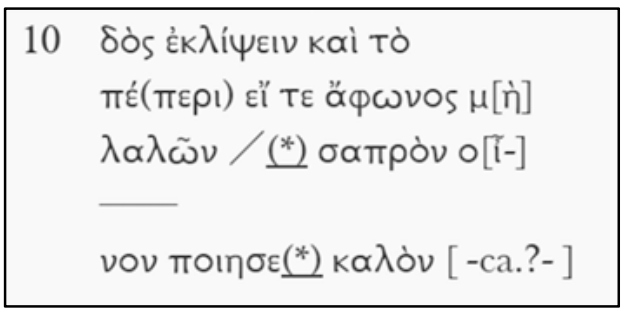

Fig. 5: SB XXVI 16458,10-13

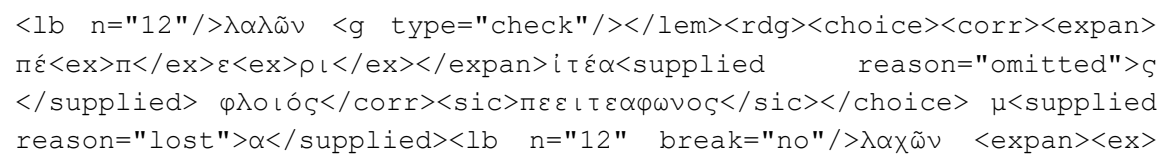

paragraphoi may actually mark a subdivision between structural text parts, but the underlying rationale in the papyrological markup seems to be that they represent graphical separators or turning points marked by the ancient scribe.

118 On these peculiar signs cf. BARBIS LUPI 1994 (paragraphos), BARBIS LUPI 1988 (diple obelismene), SCHIRONI 2010, 16-18 and passim (koronis).

$119 \mathrm{~A}<\mathrm{hi}>$ tag would probably be better: see below the case of eisthesis/ekthesis. 


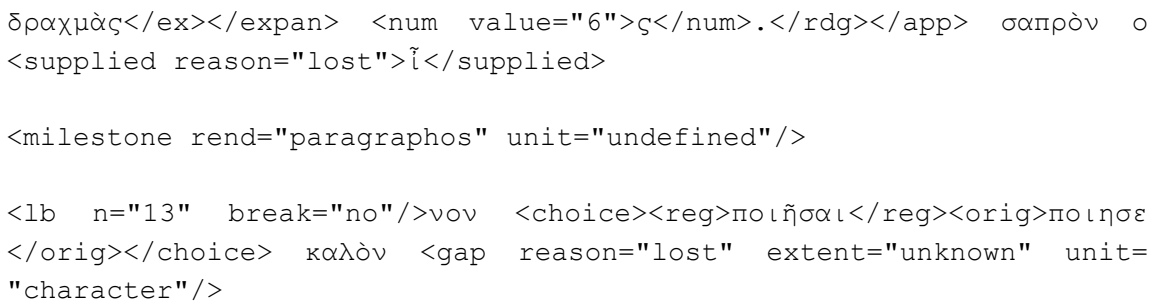

In such cases, the sign is reproduced as in the original text, but the semantics is odd; moreover, word breaks between two lines separated by a paragraphos seem not to be handled by the searching engine. It is quite clear that rigid textual units lose relevance when one deals especially with technical texts, and a separate layer to record the paratext in all its multifarious relations with the text may prove useful. ${ }^{120}$

Blank spaces are a particular category of paratextual devices that deserves a thorough reflection. If the main purpose of punctuation is to divide text portions, then it is possible to think that any "space deliberately left blank [inside a text] is also to be considered as a mode of punctuation". ${ }^{121}$ The traditional way of referring to deliberate blank spaces is the vacat, which is rendered with a $<$ space $>$ tag in TEI/EpiDoc (with the very same attributes as the $\langle\mathrm{gap}>$ mentioned above). Of course, encoding recurring blank spaces like those deployed in P.Col. IV 122 (official letter, 181 BC, http://papyri.info/ddbdp/p.col;4;122) to separate almost every word from one another would be impossible, if not in a different layer than text. Normally, the vacat is to be marked up when it introduces a significant break in the text. ${ }^{122}$ Peculiar cases as in P.Oslo III 72,9 (medical treatise about epilepsy, II AD, http://litpap.info/dclp/63583), where (according to the editors' interpretation) the ancient scribe left a blank gap to pinpoint a controversial point, should be further (or differently) annotated in order to preserve the original intentions. ${ }^{123}$

The handling of blanks is connected to the problem of how to encode ekthesis and eisthesis, i.e. extension and indention of a line with the purpose of highlight particular phrases, which has never been taken into consideration before for documentary papyri. Among the medical texts, this device is frequently deployed in the questionnaires or catechisms. Such a text typology provides medical notions in a dialogue format, where a question about theoretical definitions or practical procedures is followed by

120 Diacritics and lectional signs added by different hands are another case of uneasy elaboration.

121 TURNER 1987, 8; cf. also CRIBIORE 1996, 83 ("Blank spaces can be used as punctuation”).

122 Vacat can be used also to render columnation in particular layouts (lists, accounts, etc.), but the use is not standardized. See the chapter by L. Berkes in this volume for some remarks on the markup of layout in documentary papyri. Very recently, DICKEY 2017 has dealt with particular layouts of bilingual texts, where the columns are handled with blank spaces.

123 This case is currently encoded as an editorial apparatus note displaying the omitted text. 
a more or less detailed answer. ${ }^{124}$ Its use as a handbook, a reference tool for the doctors' preparation, is clear also from the complex set of devices employed to highlight the articulation of the text: questions are very often indented in eisthesis, and further marked with paragraphoi, line fillers or other lectional marks that introduce the answers as well. This mise en page reflects the central role played by the question-andanswer structure of the didactical tool, ${ }^{125}$ and must be preserved when the texts are moved to any modern format. This is not only a matter of reproduction. In the overall framework of difficulty of recognizing textual genres ${ }^{126}$ due to the fragmentary state of the scattered sources preserved to us, scholarship relies on any possible feature for a better understanding of ancient texts, and some very fragmentary texts have been identified as questionnaires just on the basis of the presence of blank spaces (P.Oxford Sackler s.n., II century BC; ${ }^{127}$ more recently GMP I 6 and P.Strasb. inv. 849): ${ }^{128}$ it is therefore unconceivable to encode such texts without paying attention to their paratextual garment.

It is tempting, at a first stage, to equate an eisthesis to an initial vacat and therefore to encode it like that. However, as we have to encode not the visual appearance of the text but its semantic core, we must be aware of the fact that we are not describing a certain extent of space intentionally left without characters, but a displacement of the line beginning to stress its relevance. ${ }^{129}$ Its specular counterpart, ekthesis, makes the picture clearer: by no means can it be indicated by creating weird virtual vacats at the beginning of the surrounding lines. The current solution is to mark it as an attribute of the line: <1b $n=" 1$ " rend="indent" / >, which in Leiden+ appears as $(1$, indent) - the same way marginal annotations are tagged (see below; for ekthesis the value "outdent" is to be used). ${ }^{130}$ This seems to work fine, and is now fully supported by the DCLP platform also in terms of visual display.

124 Cf. REgGIANI 2016b with earlier bibliography; also BONATI 2018 e.

125 Cf. ANDORLINI 1999; REgGIANI 2018h.

126 Cf. ANDORLINI 1997b, 159, and see above.

127 Cf. BARNS 1949, 4-5. Online: http://litpap.info/dclp/65633.

128 Cf. HANSON - MATTERn 2001, 72 and MAGDELAine 2004, 63, respectively. Online: http://litpap.info/dclp/69007 and http://litpap.info/dclp/69028.

129 On the ecdotic relevance of line displacement in the system of the margins of the Greek literary papyri see SAVIGNAGO 2008 (cf. also TURNER 1987, 8).

130 In medical papyri ekthesis is somehow less frequent than eisthesis; a significant case is presented by CoRAZZA 2018a. See also P.Oxy. XIX 2221r + P.Köln V 206r (http://litpap.info/dclp/61916), the aforementioned commentary to Nicander's Theriaka, where the lemmas containing the commented passages are highlighted by ekthesis (cf. ANDORLINI 2000, 39) and the comments are introduced by larger blank spaces, which might be considered as eistheseis. 


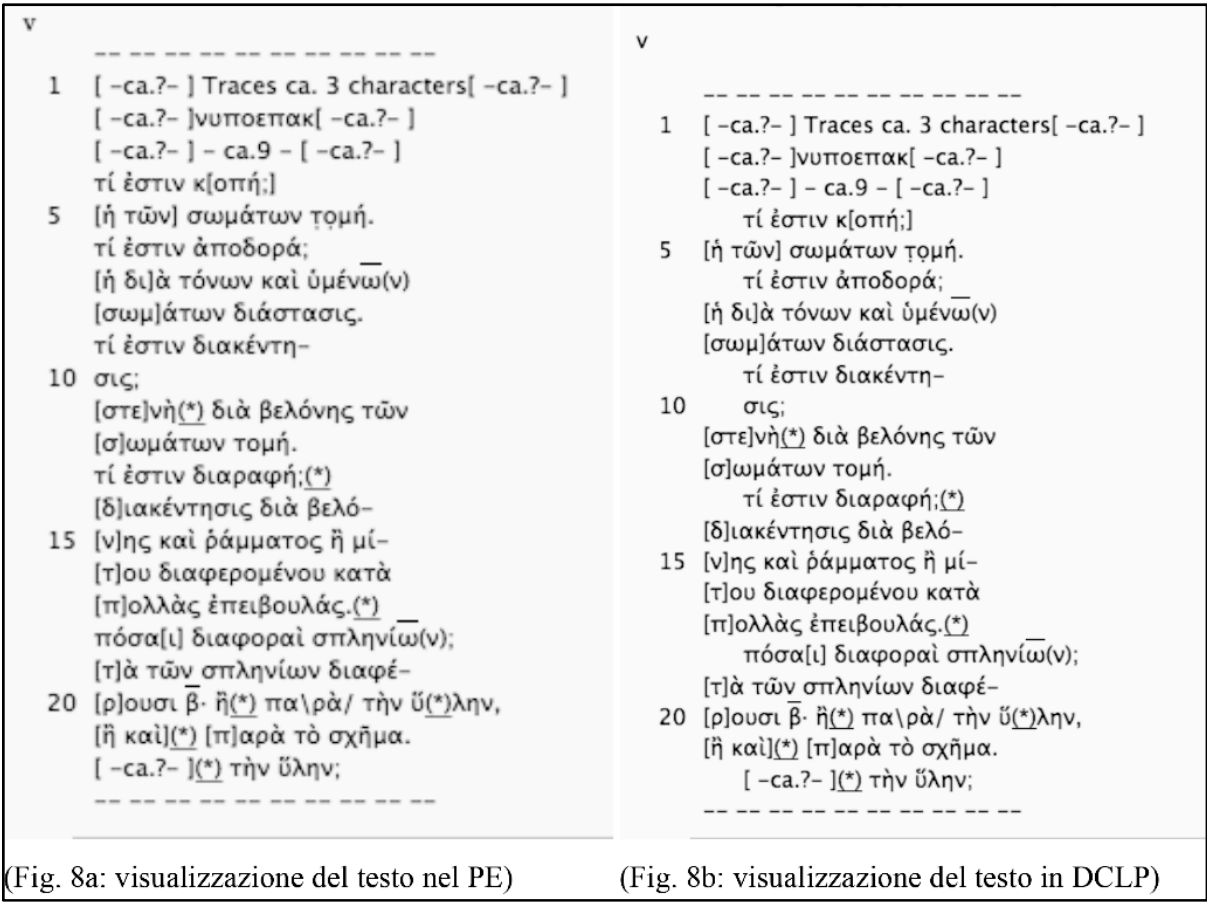

Fig. 6: A nice comparison between the earlier SoSOL preview display and the current DCLP rendering of eisthesis in P.Gen. inv. 111, catechism, http://litpap.info/dclp/63819 (BERTONAZZI 2018a, 42).

However, a further problem arises if we consider that in some catechisms the questions do not start in a new line, but on the same line as the end of the previous answers, after a blank space that cannot be considered as a vacat for the same reasons as above. In this case, if we tagged the entire line as in eisthesis we would not represent the situation correctly, since the first part of the line is not really indented. A new solution might be to tag the question phrase with the TEI/EpiDoc XML $<$ hi $>$ element, which is used to sign "highlighted characters or words", "with a rend attribute specifying the kind of highlighting", ${ }^{131}$ In our case, the value of the rend attribute would be "eisthesis", i.e. $<$ hi rend="eisthesis" $></$ hi $>$ (or "ekthesis" in the other case), which is not supported by SoSOL currently. ${ }^{132}$

131 Cf. http://www.stoa.org/epidoc/gl/latest/trans-charactershighlighted.html.

132 Cf. REGGIANI 2018h, where I advanced a further distinction of eistheseis according to their appearance in the texts. It is worth noting that encoding eisthesis/ekthesis as a $<\mathrm{hi}>$ element would prove helpful also when handling whole indented/outdented paragraphs (see the sample in the Conclusions below), instead of marking each line. 
The $<\mathrm{h} i>$ tag handles also the markup of ancient diacritical signs originally added by the scribe, ${ }^{133}$ which has always been well developed since the earlier times of Papyri.info. The canonical cases are accents (acute, circumflex), spirits (lenis, asper), diaeresis, either alone or in combination, marked with a rend attribute, the value of which corresponds to the name of the sign. Leiden+ markup is rather intricate (they must be added in the proper Unicode character inside a pair of brackets just after the appropriate letter, which in turn must be always preceded by an extra space, in whichever position it occurs in the word), but fortunately the editorial platform offers quite a helpful menu to automatically perform the task. It is worth noting that the presence of ancient diacriticals is noted in the apparatus.

The occurrence of images within the text is currently handled as well. The $<\mathrm{fig}-$ ure $>$ tag is used, and a free description of the picture can be inserted in a nested $<\mathrm{figDesc}>$ tag; Leiden+ simply indicates it with the free description preceded by a hash mark. In medical papyri this proves quite useful when dealing with the cases of illustrated herbals, where the extant images can be easily encoded with \#plant (= $<$ figure $><$ figDesc $>$ plant $</$ figDesc $></$ figure $>$ ). ${ }^{134}$

\subsection{Intertextuality \& hypotextuality}

Intertextuality is defined as the relation between parallel text, in the form e.g. of quotation or allusion; ${ }^{135}$ hypotextuality (with its opposite, hypertextuality) as the relation between a text and a preceding one that is transformed, modified, elaborated or extended. Due to the high degree of both theoretical and practical re-elaboration of medicine - "reperformance", in a sense, to borrow a term created to describe the interplay between text transmission and representation in classical drama ${ }^{136}$-, medical papyri show a complex degree of both inter- and hypotextuality. Not only are the 'classical' medical treatises and handbooks copied following the original text, but they are also quoted, or referred, or re-elaborated in other writings ${ }^{137}$ (anonymous treatises as well as manuals, catechisms or collections of prescriptions, and of course commentaries) and excerpted by the late compendiasts (Oribasius, Aetius, Paul of Aegina), who took and interwove excerpts from the earlier authors in order to create composite texts, with the purpose of assembling the best from previous writings. ${ }^{138}$

133 On this typology of signs cf. TURNER 1987, 10-12; CRIBIORE 1996, 83-8; COLOMO 2017; AST 2017.

134 P.Tebt. II 679 + P.Tebt.Tait 39-41 (II AD): http://litpap.info/dclp/63596; P.Johnson + P.Ant. III 214 (IV-V AD): http://litpap.info/dclp/64598 (cf. REGGIANI 2018i).

135 Cf. WORTON - STILl 1990; POLACCO 1998; BERNARDELli 2000; BERNARDELLi 2010, esp. 9-62.

136 FINGLASS 2015.

137 On the concept of intertextuality applied to ancient quotations cf. BERTI 2012, part. 439-46, about ancient historians.

138 Cf. HANSON 1997,296; ANDORLINI 1997a, 19-20. 
The interconnection between all such parallel or derived texts is of the utmost importance for evaluating the history of medical science, the dynamics of ancient textual transmission, and the framework of literacy among medical experts, so that an annotation layer that may link the actual text on the papyrus to any relevant related passage in other sources would be most useful. ${ }^{139}$ In the cases of papyri preserving 'literary' works (Hippocrates, Galen, etc.), for example, our fragments quite often do provide more genuine readings than manuscript tradition, since they are chronologically closer to the source; ${ }^{140}$ they can therefore support some manuscript versions against others, or even preserve previously unattested variants, facts that deserve a particular attention.

A small selection of significant samples will suffice. In P.Oxy. XIX 2221r + P.Köln V 206r (http://litpap.info/dclp/61916), the abovementioned I-century AD commentary to Nicander's Theriaka, the extant quoted passages generally agree with the more recent manuscripts of Nicander's tradition $(=\omega)$ against the ancient codex Parisinus $\Pi$, and show also new genuine variants. ${ }^{141}$ The comments, in turn, do not show many points in common with the known scholiastic tradition, and may be traced back to the most ancient comment to Nicander's Theriaka, that by Demetrius Chlorus. ${ }^{142}$ In the Aberdeen Hippocratic papyrus (GMP I 1), already cited with regards to the adaptations to the Greek language spoken in Egypt, we do find variants already attested in the manuscript tradition (11. 4-5) but also passages completely divergent from the codices (1l. 11-12, where the length of the gap and the shape of the following traces exclude the unanimous manuscript tradition, which is of course printed in all the editions, in favour of a previously unattested variant). ${ }^{143}$

Alignment among parallel versions of the same text, by linking external resources providing canonical literature, ${ }^{144}$ can therefore convey precious information and significant analysis tools, and can be well extended to all the cases (even documentary

139 So far, this has been possible only in the line-by-line commentary: cf. BERTONAZZI 2018b and CoRAZZA 2018a for discussion and case studies.

140 Cf. ANDORLINI 1997a, 22 n. 15 and 23.

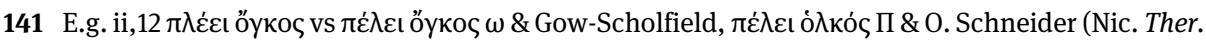
387). According to CoLonNa 1954, the original text could have been $\pi \lambda \varepsilon \dot{\varepsilon} \varepsilon$ ó $\lambda$ Kó, subsequently popu-

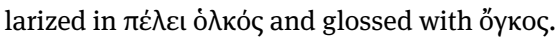

142 Full analysis in Colonna 1954.

143 Cf. ANDORLINI 2001. For another Hippocratic papyrus preserving an interesting and complex textual history (P.Ant. III 184, VI AD, http://litpap.info/dclp/60192) cf. HANSON 1970; in particular, "the sequences of the Hippocratic texts do not correspond to the one established in medieval tradition but seem to follow autonomous criteria" (CoRAZZA 2018b, 174).

144 While digital repositories of literary texts do exist, they usually do not record all manuscript variants of the texts (see above); they could well be connected to the papyrus texts but information would be partial. A possible solution may be to create multitextual digital editions of the literary texts. It is important, of course, to distinguish parallel passages in copies of the same text from quotations embedded in different texts; for the latter, the current platform offers the possibility to deploy the $\langle q\rangle$ 
ones) of texts preserved in more than one item (copies, duplicates). ${ }^{145}$ It would also solve the problem of encoding philological variants and manuscript readings in the papyrological digital editions, a challenge faced during the construction of the DCLP database and not yet satisfactorily solved. ${ }^{146}$ Alignment of ancient or modern translations of the medical texts (e.g. Latin or Arabic versions) should also be taken into consideration, ${ }^{147}$ while a fruitful integration between syntactic annotation/analysis and intertextual referrals may be envisioned for the most intriguing issues of medical literature, as recently argued by Francesca Bertonazzi:

l'analisi del lessico tecnico dei papiri chirurgici ha portato a individuare paralleli testuali tra testo tramandato su papiro e tradizione manoscritta, talvolta significativamente stringenti come nel caso di P.Strasb. inv. 1187 e diversi passi di Eliodoro ap. Oribasio. Alcuni altri papiri (P.Lond.Lit. 166, P.Gen. inv. 111, P.Fuad.Univ. 1, P.Ryl. 3.529), come già notato dagli studiosi, sono caratterizzati da una forte presenza di 'lessico eliodoreo’ e da alcune peculiarità proprie del modus operandi del chirurgo, come la predilezione di interventi chirurgici che siano il più sicuri

tag marking quoted phrases (Leiden+: quotation marks + space), which can be easily used to differentiate the appropriate cases.

145 Traditionally, documentary papyri preserving the 'same' text in multiple copies (for a catalogue of duplicates cf. NIELSEN 2000) are treated in the 'philological' way, i.e. collated and merged in one source archetype: e.g. http://papyri.info/ddbdp/p.tebt;3.1;771dupl (note the suffix 'dupl' added to the URL of the digital text, which advises about the existence of a duplicate of the papyrus). However, a certain degree of uneasiness is felt about such a practice, see e.g. in Jelle Stoop's words: "I disagree with this editorial choice for two reasons. First, in a field like papyrology, every copy of a text deserves full consideration and [...] an archetype that would somehow be considered more authentic than a later copy is an editorial fancy. Copies of the same text, however similar, were written with a purpose in mind, so that edition should be more rather than less interesting. Second, in order to appreciate the fact that we have multiple copies [...], we must ask why different versions of it exist in the first place. The interest of these documents is, therefore, not restricted to the text alone, but extends to the life and afterlife of its copies in relation to one another. In sum, the text of just one fragment does not make for a satisfactory edition of understanding of this [text]. By editing the texts in their own right, we learn about the convention of [...] writing in [Graeco-Roman] Egypt" (STOOP 2014, 185). A new "phenomenological' consideration of papyrus copies is emerging (cf. YUEN-COLLINGRIDGE - CHOAT 2012, with interesting preliminary comments on textual differences between copies of the same document), but, for now, the digital database is following the 'philological' practice, with a significant loss of information. Giuditta Mirizio (Bologna) is currently working on this topic also from the perspective of digital encoding and XML annotation. On this topic, see also below.

146 The proposed tag (<app type="variant" $\rangle$, Leiden $+|\operatorname{var}|)$ raised some theoretical and methodological issues, for example whether to choose just one manuscript variant or to encode all possible instances. Moreover, the $<$ app $>\operatorname{tag}$ (see below) typically envisages a "lemma" $(<l e m>$ ) part, which corresponds to the word(s) in the text, and one or more "reading" part(s) $(<r d g\rangle)$, corresponding to the alternative(s) in the apparatus, and it must be clearly thought how this should work in the case of philological variants. Currently, the Digital Corpus of the Greek Medical Papyri has adopted the solution to just describe the most relevant manuscript variants in the line-by-line commentary. 147 On translations in the tradition of ancient Greek medical texts see e.g. GAROFALO - FoRTUNA LAMI - ROSELLI 2010. 
possibili per il paziente, nonché del modus scribendi, come il ricorso frequente alla prima persona - singolare o plurale -, la definizione con esattezza delle posizioni 'topografiche' della parte operata (dentro, fuori, sopra, sotto), e una sostanziale semplicità delle strutture sintattiche usate. Ad oggi, i tentativi di attribuire i papiri citati alla paternità di Eliodoro si sono basati quasi esclusivamente su criteri lessicali nel confronto tra il testo tramandato su papiro e sui capitoli di Oribasio che portano la titolatura 'da Eliodoro'. Una nuova possibile strada offerta dalle nuove tecnologie della papirologia digitale è quella costituita dall'annotazione sintattica dei testi: un'analisi più accurata non solo del lessico, che come è noto è la parte più 'volatile' della lingua, ma delle strutture morfologiche e sintattiche dei passi del compilatore tardo in sinossi con i testi dei papiri, sia pure nella limitatezza delle pericopi testuali preservate, potrebbe gettare nuova luce anche su questo aspetto tra i più incerti quanto stimolanti della ricerca. ${ }^{148}$

Re-elaboration is probably the most striking feature of technical texts, stemming from oral teaching and then continuously adapting their content according to the developments of knowledge. Medical genres like the questionnaire or the collection of prescriptions illustrate this framework at the best, though we do find plenty of crossreferences in treatises too. ${ }^{149}$ Catechisms (erotapokriseis), for example, are clearly derived from and devoted to some sort of oral teaching, as we pointed out above while discussing of their paratextual devices. Yet there exists a considerable similarity with the literary genre of the "definitions", connected with the research and teaching practice of Hellenic medicine and attested in the Greek Pseudo-Galenian treatise Horoi or Definitiones Medicae (XIX 346-462 Kühn) and in the Latin Pseudo-Soranian Quaestiones medicinales. ${ }^{150} \mathrm{In}$ fact, David Leith has recently distinguished two types of question-and-answer medical texts: the proper catechisms, being introductory manuals for the student of medicine, and wider treatises on remedies. The suggestion came from the similarities detected between erotapokriseis on papyrus like P.Turner 14 (http://litpap.info/dclp/63560) and PSI inv. 3783 (http://litpap.info/dclp/63244) and the excerpts from the physicians Herodotus and Antyllus preserved in Oribasius' Collectiones Medicae. ${ }^{151}$ One may also recall the similarities between the abovementioned P.Oslo and P.Oxy. overlapping questionnaires, or between the surgical catechism P.Gen. inv. 111 (http://litpap.info/dclp/63819) and the treatise known as Cirurgia Heliodori, ${ }^{152}$ or also between P.Aberd. 11 (http://litpap.info/dclp/63332) and

148 BERTONAZZI 2018a, 242-3.

149 Cf. e.g. ANDORLINI 2014. "La possibilità di identificare alcuni papiri con trattazioni di un autore tramandato solo indirettamente inserisce tasselli nuovi nella complessa stratificazione della trasmissione indiretta, soprattutto quando sono i papiri i soli testimoni diretti di autori tramandatici per excerpta e citazioni (Apollonius Mys, Heras, Heliodorus, Herodotus Medicus)” (ANDORLINI 1997a, 22).

150 On which cf. KOLLESCH 1963 and FISCHER 1998 respectively. For general considerations about catechisms on papyrus see also BONATI 2018e and BERTONAZZI 2018a, 57-62 , as well as REGGIANI 2016b.

151 LEITH 2007; cf. already ANDORLINI 1997b, 160.

152 Cf. MARGANNE 1986 and now BERTONAZZI 2018a, 237-8. 
P.Ross.Georg. I 20 (http://litpap.info/dclp/63569), two ophthalmological catechisms that certainly derive - with variations - from the same source. ${ }^{153}$

Prescriptions are even more complex (and fluid) in transtextual and hypotextual relations. I have extensively dealt with transmission of ancient medical recipes elsewhere, where I outlined the articulated route from oral compositions and draft transcriptions to professional exchange and collection. ${ }^{154}$ Medical prescriptions are fragmentary units, which stem from diagnostic-therapeutic practices and oral knowledge that are recorded on wax tablets (pinakes), first kept at the sanctuaries of the healing gods, then collected by leading physicians (namely Hippocrates) in order to build systematic medical repertories. ${ }^{155}$ At this stage it is hard to trace any actual intertextual relation, but when - seemingly in the early Roman age - prescriptions start circulating among the physicians, the plot gets intricate. Professional doctors exchange single recipes on papyrus scraps with each other and collect those fragments of medical knowledge into lists and catalogues on parchment booklets, deploying a set of paratextual devices to preserve the unity of each prescriptive text. Galen is the best witness to this 'research' activity, ${ }^{156}$ as well as of the 'philological' attention to the pharmacological books held by the libraries, which he himself consulted and collated to get the most exact versions of the texts and to compile his famous treatises on the composition of remedies. ${ }^{157}$

This workflow is by no means exhausted with Galen: among the numerous possible examples, P.Berl.Möller 13 (http://litpap.info/dclp/64268) is a stunning instance. This papyrus, a comparatively large portion of a roll from Hermoupolis Magna, dated between the late III and the early IV century AD, is written on the recto

153 Cf. BERTONAZZI 2018a, 236-7, with earlier bibliography.

154 REgGIANI 2018g and 2018j.

155 Cf. TOTELIN 2009a, part. chapters 1-3.

156 Comp.med.loc. I 1 = XII 423,13-15 K. (a recipe is found in a dead physician's parchment notebook and then forwarded to Galen); Antid. I 5 = XIV 31,10-15 K. (exchange of recipes); Indol. 33-5 (his own personal collection of worldwide prescriptions, destroyed by the AD 191 fire). See also P.Mert. I 12,1324, attesting to the very same activity of exchange between two colleague physicians in Egypt.

157 The ancient practice of collating several copies (antigrapha) of medical texts is attested above all by Galen, who noted several degrees of manuscript divergences, ranging from small linguistic variations to major discrepancies in the content, e.g. in the ingredients and quantities (cf. ANDORLINI 2000, 38-9; ANDORLINI 2003, 14-15; TOTELIN 2009b; BONATI 2016b, 64-5), but we know of other cases in which the ancient readers produced 'personal' copies that became, by means of reformulations and abbreviations, new recensions of the same text (cf. ANDORLINI 2000, 37-8). In some cases it is possible to speak of erroneous or inaccurate deviations from the original (it is the case with Galen's treatises, for which the ancient author himself stigmatised the circulation of incorrect versions of his own books: De libris propriis II 91-3 Müller = XIX 8-11 K.; cf. HANSON 1985, 43-5) but in other cases it is difficult to go back to a genuine text (HANSON 1985, 34-5 makes the example of Hippocratic letters). In general, on Galen's 'philological' work cf. HANSON 1998; ANDORLINI 2003, 15-16; DORANDI 2014; BONATI 2016b, 63-5. 
along the fibres, therefore purposely produced as a collection of medical prescriptions, of which only two columns survive. The first one contains a single prescription "to prevent hair loss on the head", identified by MARGANNE 1980 as a prescription ascribed by Galen to Heras of Cappadocia, a pharmacologist active between $20 \mathrm{BC}$ and AD 20. The text on the papyrus parallels Gal. Comp.med. loc. XII 430,8-15 K. verbatim, ${ }^{158}$ while other variant versions of the same remedy are recorded by Galen himself (ibid. XII 435-6 K.) as antecedents of Heras' one. ${ }^{159}$ Subsequently, CoRAzZA 2016 discovered that also some remnants of the second column can be identified with other recipes by Heras, this time against headache, mentioned by Galen as well, with some wording variants. ${ }^{160}$ Two of them patently parallel Galen, but the papyrus is by no means a copy of On the composition of medicaments by places: the recipes do not follow the canonical order in which they are cited in Galen's treatise, clearly attesting a work of selection, extraction, and thematic re-arrangement, in which each recipe is treated as a unit to be managed on its own; moreover, the other two identified prescriptions look like variants of Heras' texts as reported by Galen, thus attesting a 'fluid' stage of transmission, in which recipes are modified and adapted according to the users (Galen himself, as we saw, attests some earlier versions of Heras' recipe against hair loss). It is apparent that this interconnection of "living texts", ${ }^{161}$ copied and re-copied from original pieces or different collections, generates cross-references and inter-quotations that may well fall into the cases described in these paragraphs. ${ }^{162}$

\subsection{Metatextuality}

Metatextuality is the explicit or implicit critical commentary of one text on another text. For the same reasons described above apropos of paratext and intertextuality, namely the fluidity of medical technical texts, always subject to renovation and up-

158 In fact there are some interesting variants, which as usual show how papyri can contribute to

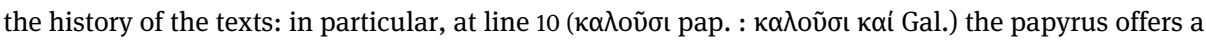
superior reading, since the conjunction is syntactically unfit; further discussion in CORAZZA 2016 ad locc. On the value of the variants attested in the papyri see above.

159 Cf. MARGANNE 1980, 182-3.

160 In particular, the first prescription of the second column (ll. 1-3) parallels Gal. Comp.med.loc. XII 593,14 K. verbatim, while the following two (ll. 4-8 and 9-15) show partial overlaps with ibid. XII 594,1-4 (= Aet. VI 50,75-9) and XII 594,7 ff. K. All these recipes are ascribed to Heras. The remaining traces of fifteen lines, articulated in four more recipes, could not be identified with any known text.

161 BONATI 2016b, 66.

162 The Leiden+ tag for parallel passages is meant to mark omitted text that is supplied on the ground of parallels, so it does fall into a different typology (see below, editorial interventions). 
date after practical and individual experience, the practice of annotating is widespread in the medical papyri. ${ }^{163}$ The annotations can acquire either the organic format of the commentaries, autonomous exegetic treatises, the most illustrious examples of which are Galen's commentaries on Hippocratic texts ${ }^{164}$ (see e.g. Gal. In Hp. Epid. II 4 = CMG V 10,2,1, p. 78,7-11 Wenkeback, where the author himself explains some reasons for compiling commentaries), or the scattered aspect of the scholia or marginal annotations: see the examples of P.Ant. I 28 (http://litpap.info/dclp/60189), fragment of a III-century parchment codex from Antinoupolis with the text of Hippocrates' Aphorisms and marginalia, ${ }^{165}$ as well as of P.Ant. III 186 (http://www.litpap.info/ dclp/59961), a very fragmentary large-format papyrus codex from the same place, dated to the VI cent. AD, which contains sections of Galen's De compositione medicamentorum per genera along with some scanty marginal annotations. ${ }^{166}$

In both cases, textual relations are complex. ${ }^{167}$ Commentaries refer to other texts but without exact parallels, except for literal quotations (see above); marginal notes refer to the main text without being part of it, so that the current treatment in digital editions may be slightly misleading, since it allows for marking the marginality of the passage (added to or written into the margins), but not the type of relation with the main body of the text. ${ }^{168}$ The XML syntax is clear: marginalia are encoded as plain text lines, with the indication of the margin attached to the line number. ${ }^{169}$ Let us consider, instead, a more complex case, represented - again from Antinoupolis - by P.Ant. III 126 (http://litpap.info/dclp/65233):

P.Ant. 3.126 (VI-VII secolo d.C.) è parte di un compendio sul trattamento farmacologico e chirurgico della tonsillite e rappresenta un esempio di 'enciclopedia medica' redatta in epoca bizantina; il ritrovamento di testi come questo conferma l'idea che nella pratica medica antica la trasmissione del sapere avvenisse tramite la combinazione di fonti tradizionali, tramandate per tradizione scritta, e di materiale desunto dalla pratica medica quotidiana e registrato proprio dagli specialisti che operavano sul campo.

Il testo principale, ovvero quello scritto in carattere più grande nella parte più estesa di papiro, è arricchito da annotazioni nel margine inferiore che riguardano alcune terapie farmacologiche da impiegare nel caso dell'insorgere delle patologie descritte nel testo, e tale modalità di uso e

163 On the practice of annotating medical treatises with scholia and comments cf. ANDORLINI 2003; in general, on scholia and commentaries in the papyri cf. MESSERI SAVORELLI - PINTAUDI 2002..

164 Cf. MANETTI - ROSELLI 1994.

165 cf. ANDORLINI 2000, 41-2; ANDORLINI 2003, 19-24

166 Cf. CORAZZA 2018a.

167 The two cases are tightly related, and can even merge together in the so-called "commented editions" discussed by VANNini 2015.

168 See the observations by CORAZZA 2018a. On the interactions between text and glosses, very interesting is the analysis by MANIACI 2002, though referred to later types of texts.

169 E.g. $<1 \mathrm{~b} n=" 1, \operatorname{minf} " />$ for lines in the bottom margin (the other margins are indicated with msup, ms, md). In Leiden+ this information is added to the line number accordingly. 
riuso del testo testimonia l'iter con cui il sapere tradizionale era compendiato, arricchito e integrato nei libri tecnici dai possessori dei testi. Le caratteristiche di layout, la consistenza dei margini (quello inferiore, quasi totalmente conservato, misura $5 \mathrm{~cm}$ ) e la scrittura regolare, oltre all'indicazione in alcuni punti degli spiriti, lasciano pensare che il frammento fosse parte di un codice di notevoli dimensioni e, dunque, di un certo pregio; il tipo di annotazioni riportate nel margine, anche in mancanza di notizie più specifiche circa l'uso di questo codice, fanno pensare che il redattore potesse essere un medico piuttosto competente o un soggetto forse ancora in formazione ma abituato alla pratica medica. ${ }^{170}$

The relation between the marginalia and the text is tight, though the current markup can be arranged just as follows:

\section{P.Ant. 3.126, Fr. A}

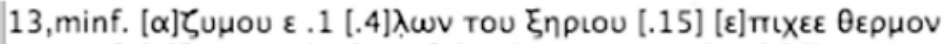

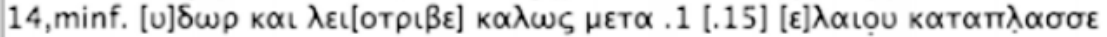

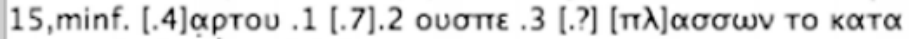

16,minf.- [ $[\pi \dot{\alpha} \alpha \sigma \mu \alpha][. ?]$

Fig. 7: Sample markup of marginalia according to the current standards (from BERTONAZZI 2018a, 73).

It is clear that we are not dealing with simple additions to the text, which are easily encoded with the $<$ add $>$ tag, further specified - with the place attribute - according to the position of the insertion (above, below, left, right, interlinear). ${ }^{171}$ Scribal additions can be effectively utilized under particular circumstances, as in the case of P.Oxy. IX 1184v (http://litpap.info/dclp/60175), a I-century AD fragment exhibiting part of a collection of Hippocratic epistles likely arranged by theme (the extant texts deal with Hippocrates' invitation to Persia by the Great King, which he self-confidently refuses). ${ }^{172}$ The papyrus contains different versions of the Pseudo-Hippocratic letters 3, 4, 4a, 5, and 6a (ed. Smith), separated by initial ektheseis, and paragraphoi between each other. ${ }^{173} \mathrm{Ep} .3$ is shortened at the end, and its 'canonical' conclusion has

170 BERTONAZZi 2018a, 53-4; cf. also ibid., 73 for its digitization; CoRAZZA 2018b, 46-57; on the annotations, MCNAMEE 2007, $463 \mathrm{ff}$.

171 For the cases of scribal additions, Leiden+ recovers some traditional Leiden conventions, so that supralinear insertions are encoded between two slashes $(\backslash x /)$ and infralinear insertions with reversed slashes $(/ / x \backslash \backslash)$. The other types of additions are rendered as || left: $x||,|| r i g h t: x||$, | |interlin:x||.

172 Cf. BRODERSEN 1994, 103-7.

173 The papyrus presents also interesting cases of intertextuality (see above): of Ep. 5, it transmits the shorter form with certain variations, while Ep. 6a, a letter to Gorgias previously unattested, has striking coincidences of phraseology with 'canonical' Ep. 6, addressed to Demetrius. 
been appended as a supralinear insertion flowing into the right-hand margin - this is easily encodable with a combination of the two relevant <add>tags. But then Ep. 4 was transcribed twice, in an abridged version in the main text, flanked by a shorter form without the introductory salutation (Ep. 4a), added into the right-hand margin and separated from the main body of letter 4 with an irregular vertical line. Further below, between letters 4 and 5 (1l. 17-19), three lines of comment appear, unattested elsewhere.

Marginal or interlinear additions merge with comments in a complex metatextual net that sometimes overflows into the text itself ${ }^{174}$ and show a remarkable 'philological' care for the text by the ancient scribes. The case of Hippocrates' fourth letter, described just above, is rather meaningful: the marginal text is not a comment (like the following interlinear insertion) nor an addition (like the preceding supplementary insertion), it is an alternative parallel version, a proper variant of the text presented in the main body of the papyrus. In this case, the vertical, irregular line traced by the ancient scribe to divide the two alternatives acts as a proper indication of a textual variant. ${ }^{175}$ We do find even more puzzling instances. P.Tebt. II $272 \mathrm{v}$ (http://litpap.info/dclp/60048, late II cent. AD) is a fragment of Herodotus Medicus' De Remediis, describing the symptomatology of thirst and its treatment; the text corresponds in part to an excerpt of Herodotus Medicus preserved with Oribasius' treatment of thirst in case of fever (Coll.Med. V 30, 6-7 Raeder = CMG VI 1,1). At a certain

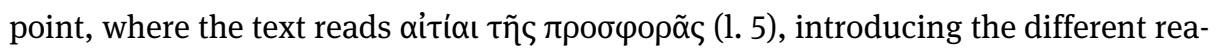
sons for giving the sick something to drink, the scribe added two groups of three letters between dots above the line: ${ }^{176 \star} \tau \tilde{\omega} v^{\star}$ above $\tau \tilde{\eta} \varsigma$, and ${ }^{\star} \rho \tilde{\omega} v^{\star}$ above $\rho \tilde{\alpha} c$. This is not an addition supra or infra lineam, since it is clearly an alternative to the syntagm below (plural instead of singular); and since nothing appears deleted, it is not clear if the ancient writer wanted to correct the text or just juxtapose two different versions of the same passage. ${ }^{177}$ We cannot be sure of what is going on here because this variant is unattested in the manuscript tradition, i.e. in Oribasius' passages quoting Herodotus Medicus, which all feature the singular form. We would have a scribe correcting the form unanimously preserved by the manuscript tradition and replacing it with an

174 Sometimes a marginal annotation can be swallowed up in the main text, generating a textual issue that can be likely explained only by means of metatextual correlations: this is the case with

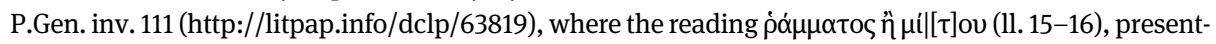
ing two technical terms that are almost synonyms, may stem from a gloss (cf. BERTONAzZI 2018a, 241-2). 175 It is worth noting that similar graphical devices are used by the author of the Anonymus Londinensis to frame alternative versions of the same passage (cf. CRIBIORE 2018 and see below).

176 I thank very much Todd M. Hickey and Derin McLeod for the help in getting a high-resolution picture of the fragment. I mention this case in REGGIANI 2018a, 2018b, 2018c, with discussion of the tentative code used to digitize it.

177 Writing a word between dots could be a way to highlight later corrections, like e.g. the koppa in P.Eirene III 25, 3 (III AD; see comment ad loc.). 
unattested variant. The P.Tebt. editors speak of "correction or alternative reading”, M.-H. Marganne of "hésitation"; ${ }^{178}$ if we should define it, we ought to call it a 'scribal variant', just as in the Hippocratic case presented above, as well as in P.Oxy. LVI 3851 (http://litpap.info/dclp/61917, II-III AD), a fragment of Nicander's Theriaka (333-4), which at 1.12 reads $\pi \rho \varepsilon \sigma \beta i \sigma \tau \alpha \tau[$ ov] (attested in most of the manuscript tradition) with $\mathrm{a} v$ added supra lineam between dots, being $\pi \rho \varepsilon \sigma \beta$ v́ $\tau \alpha \tau o v$ an alternative version attested in some of the manuscripts $(=\mathrm{Kv})$.

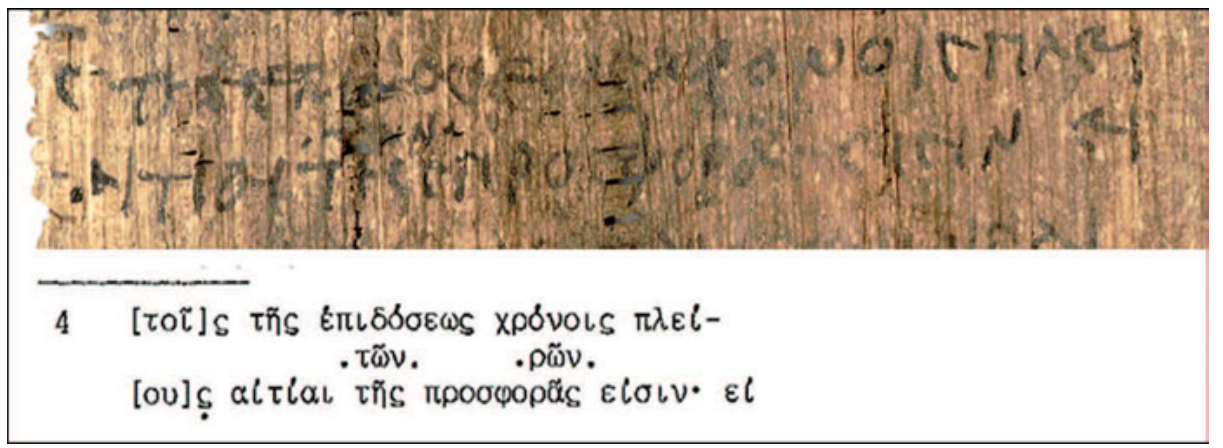

Fig. 8: P.Tebt. 272,4-5 (courtesy of the Center for the Tebtunis Papyri, University of California, Berkeley).

It is not easy to deal with these cases digitally, ${ }^{179}$ at least with the currently available tools, which deploy instead a full set of tags aimed at encoding plain scribal corrections, i.e. additions (see above), deletions (<del> tag with rend attribute describing the type of deletion: "erasure", "slashes", "cross-strokes"), ${ }^{180}$ and replacements (<subst $>$ tag containing a nested <add place="inline" $>$ tag defining the corrected text and an equally nested $<$ del rend="corrected" $>$ defining the replaced text). ${ }^{181}$

178 MARGANNE 1981b, 76.

179 TOMASI - ZAJA 2002 discuss some interesting solutions for the encoding of marginal writings, though dealing with quite later types of texts.

180 Leiden+ employs the double square brackets as in conventional printed editions; only square

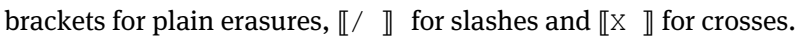

181 Leiden+ employs a | subst $\mid$ tag working the same wasy as $\mid$ reg $\mid$ and $\mid$ corr $\mid$. An interestingly complex case (P.Strasb. inv. 1187, A, i,11 = http://litpap.info/dclp/59968) is presented by BERTONAZZI 2018a, 64 and 69-70: an ancient scribal correction, involving the insertion of a letter supra lineam, was read differently by two editors, so that they proposed two different interpretations, one

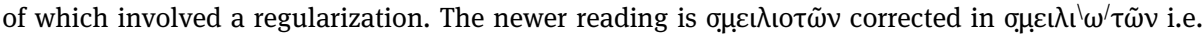
$\sigma \mu \iota \lambda \iota \omega \tau \tilde{\omega} v$; the previous reading was $v \omega . \delta \varepsilon \tilde{\imath} \lambda ı \tau \omega \nu$ corrected in $v \omega . \delta \varepsilon \tilde{\imath} \lambda_{\imath}{ }^{\prime} \omega^{\prime} \tau \omega \nu$. In Leiden+ this is

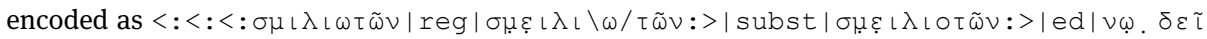
$<: \lambda \iota \backslash \omega / \tau \omega \nu \mid$ subst $\mid \lambda\llcorner O \tau \omega \nu:>=e d$.pr. : >, and the XML is cross-nested accordingly, so that the current display on the platform appears quite messed up. 
The philological care testified by the cases of 'scribal variants' mentioned above is even more patent when the text is an autograph ${ }^{182}$ and is equipped with authorial revisions, for which an important contribution can come from the XML annotation of genetic criticism phenomena recently developed by Elena Pierazzo. ${ }^{183}$ Raffaella Cribiore has recently showed how genetic criticism - aimed at reconstructing the process of authorial constitution of a text - can be successfully applied to papyrological texts. ${ }^{184}$

\subsection{Editorial interventions (modern)}

Modern alternative readings and editorial supplements do influence linguistic annotation, in that they add data, which are not stricto sensu 'original' to the text. Alternatives produce multiple possible readings, one of which is usually the most probable but without full certainty, and the other possibilities may well fit the context. Supplements, though most likely and in some cases pretty unavoidable, are nonetheless a modern contribution to the ancient fragmentary text and deserve a particular attention. They can even be incorrect, and thus fall into the third category of editorial corrections, which encompass all modern corrections made to the readings of previous modern editors. Alternatives and editorial corrections are currently encoded as apparatus elements (<app $\rangle$ ) defined by the type attribute and composed of a "lemma" $(<1 \in \mathrm{em}>)$, i.e. the word in the text, and a "reading" $(<r \mathrm{dg}>)$, i.e. the alternative in the apparatus. In Leiden+ they are marked with the $\mid$ alt $\mid$ and the $\mid$ ed $\mid$ tag respectively. Such a markup strategy works fine from the 'philological' viewpoint, since it provides a main reading - supposedly the most correct - and a set of critical alternatives, either proposed by the same editor or sedimented through years of scholarship, with the possibility to indicate the authorial responsibility for each reading (resp attribute in the $<$ lem> tag). ${ }^{185}$ Nevertheless, the impossibility to search for combination of words including the terms in the apparatus makes this choice rather uneasy for the purposes of digital databanks, while different layers of text, each one featuring a single textual

182 On medical autograph papyri cf. ANDORLINI 1997a, 22 with earlier bibliography; MARGANNE 2004, 90-1.

183 Cf. http://www.tei-c.org/Activities/Council/Working/tcw19.html; PIERAZZO 2008.

184 CRIBIORE 2018: see in particular the case of the medical Anonymus Londinensis and the related discussions of double versions. From the computational viewpoint, cf. MACÉ - BARET - BOZZI - CIGNONI 2006 (in particular, PASSAROTTI 2006). Genetic criticism can be applied to some documentary categories which show a certain complexity of textual composition. One may recall, just for instance, the legal documents of Ammon's archive, produced in multiple versions (P.Ammon II; cf. CRIBIORE 2018); Raffaele Luiselli's considerations about authorial revisions in Roman letters and petitions (LUISELLI 2010); the mostly neglected cases of duplicates recently 'rediscovered' by Malcolm Choat and Rachel Yuen-Collingridge (YUEN-COLLINGRIDGE - CHOAT 2012); the composing process of administrative reports studied in the Project Synopsis at the Heidelberg University especially by Uri Yiftach (cf. REGGIANI 2016c); the very recent discussion on drafts and copies by Andrea Jördens (JöRDENS 2017).

185 See, however, DAMON 2016 for criticism of this way of handling apparatus readings by TEI. 
alternative, may enhance the digital representation of the papyrus, especially when considering that editorial interventions occur more frequently in the medical papyri than in the documentary ones, for the peculiar attention to the editorial history that characterizes the items of the Digital Corpus of the Greek Medical Papyri. ${ }^{186}$

On the other hand, supplements are tagged as such with the <supplied $>$ element, and a reas on attribute that defines the type of integration: "lost" if the original text is lost (Leiden+ square brackets), "omitted" if the original text was left over by the ancient scribe (Leiden+ angle brackets), "parallel" if the text is inserted on the ground of a parallel text (Leiden+: pipes + underscores ${ }_{-}+\mid$). The opposite case (removal of ancient surplus text) is marked with a $<$ surplus $>$ tag (Leiden+: curly brackets). In this case, integration with the text layer is granted by the fact that the $<$ supplied $>$ tag indicates a text portion. This is even clearer if we compare it with the tag used to mark unsupplied lacunas, that is a $\langle\mathrm{gap}\rangle$ tag with a reason attribute set to "lost" (see above). ${ }^{187}$

The case of the gaps is indicative of the semantic difference between digital and paper edition. In a printed critical system, both supplied and unsupplied lacunas are marked with square brackets because the focus lies in the descriptive layer of the papyrological fact: a certain missing part of the text, which may be recoverable or not. In a digital critical context, we need to define whether a lacuna bears a textual meaning (i.e., a supplied text) or not (i.e., a gap in the text). Leiden+, following the printed conventions, adopts square brackets for both, in order to help the users; but the system automatically chooses the appropriate XML code according to the content of the brackets. Therefore, when the papyrus displays a partially supplied gap, which is enclosed by the very same pair of brackets in the printed edition, in the digital edition the two different parts (supplied and unsupplied) must be kept separated since they mean two different facts. Leiden+ brackets are different than Leiden printed ones also in that the former must be always opened and closed at each gap, while in a printed edition they can be left open (or unclosed) if their exact extent is unknown.

Somehow ambiguous, in conclusion, is the treatment of modern corrections in the case of misspelled words. Though the typical treatment involves the $\mid$ reg $\mid$ and

186 Cf. CORAZZA 2018a; BERTONAZZI 2018a, 64-7 (with case studies) and 2018b.

187 The theoretical assumption that the fragmentary status of the papyri may be thought as a (paradoxical) sort of 'non-voluntary quotation', selected by the chance and by the material circumstances rather than by the will of an author, would allow to envision a transtextual link between a 'virtual' hypertext (the original document, lost, more or less recoverable in a philological way) and the concrete hypotext (the actual fragment; cf. REGGIANI 2016a; see also ROMANELLO - BERTI - BOSCHETTI - BABEU CRANE 2009, 160 and 162: “[...] fragments do not actually exist outside of scholars' interpretations. [...] Fragments are always scholarly reconstructions and interpretations of the content and structure of lost works"). This may allow for creating several multiple layers for editorial alternatives and supplements too, thus avoiding complicated nested tags as in the case of multiple alternatives in a series of different supplements or modern editorial readings (see the samples provided in the Conclusions below). 
| corr | tags according to the type of intervention (see above), the use of traditional Leiden conventions (angle brackets for supplements of omitted letters, curly brackets for removal of surplus letters) is admitted in case of outright diplographies ("where the letter(s) is genuinely superfluous", so say the guidelines) ${ }^{188}$ or trivial omissions (for which it is preferred to the $|\operatorname{corr}|$ tag).

\subsection{Image}

When available, the addition of a digital picture is fundamental for a complete evaluation of the papyrus. The advanced possibilities of virtual objects, of which I discussed elsewhere, ${ }^{189}$ could be further enhanced by aligning text and image, a procedure that has been successfully attempted by the Anagnosis project at Würzburg. ${ }^{190}$

\section{Concluding remarks}

The so-called Michigan Medical Codex (P.Mich. inv. 21 = P.Mich. XVII 758, http://www.litpap.info/dclp/59332 ${ }^{191}$ resumes at the best most of the preceding arguments. It is a IV-century small-format papyrus codex, of which thirteen leaves survive to an amount of twenty-six pages, in which numerous recipes are collected - seemingly - according to type of medication (pills and lozenges, then wet and dry plasters, at least in the extant pieces). Commissioned by a practicing physician, ${ }^{192}$ the document shows various degrees of textual interventions. In the original writing, recipes start with an indented heading, declaring the type of remedy, and are separated from each other with lines and small blank spaces; they typically contain the list of ingredients, followed by directions for composition and use. Many prescriptions are ascribed to famous doctors, showing

correspondences with recipes for plasters in the collections of Galen, Oribasius, Aëtius, or Paul of Aegina that have come down in the manuscript traditions, highlighting the striking degree of continuity among ingredients and their relative proportions from hand-written copy to hand-written

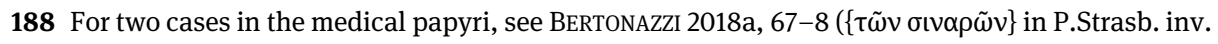
1187, A, i,14 and $\{\sigma\} \sigma x \eta \mu \alpha \tau i \sigma \alpha \nu \tau \varepsilon \varsigma$ in P.Lond.Lit. 166, iv,6).

189 REGGiani 2017, $137 \mathrm{ff}$.

190 See above and the Anagnosis section of R. Ast's and H. Essler's chapter in this volume.

191 YouTIE 1996. For the following observations, I refer to HANSON 1996, HANSON 1997, 302-4, and ANDORLINI 2003, 26-8.

192 Cf. YOUTIE 1996, 1-3; ANDORLINI 2003, 26-7. 
copy over many centuries: the presence of plasters from a variety of different physicians suggests that the basic text of the codex was combining and taking its shape over considerable time. ${ }^{193}$

Then, the interventions by the owner of the codex:

First he collated the text of his newly-made copy against an exemplar, making corrections in addition to the items already corrected by the scribe, and then he went on to more than double the contents of the codex by filling the margins with additional recipes for pills to medicate bodily ills and plasters to medicate wounds and lesions of every kind. Because empty space was limited, he emphasized separation between recipes through lines and marginal markers. ${ }^{194}$

Intertextuality, hypotextuality and similar connections merge together, creating a very complex and unique clockwork: "although individual recipes in a collection on papyrus often resemble items in the known authors, each extensive collection on papyrus has thusfar proved to be a unique assemblage". ${ }^{195}$ The paratextual function of critical and lectional marks stresses the "composite" structure of the text, ${ }^{196}$ while authorial corrections and phonetic variants are not absent from the textual level.

Let us compare a part of the printed edition with the corresponding digital edition currently featured in the DCLP, ${ }^{197}$ followed by a tentative proposal of (partial) ontology network to describe the multiple textuality of the sample.

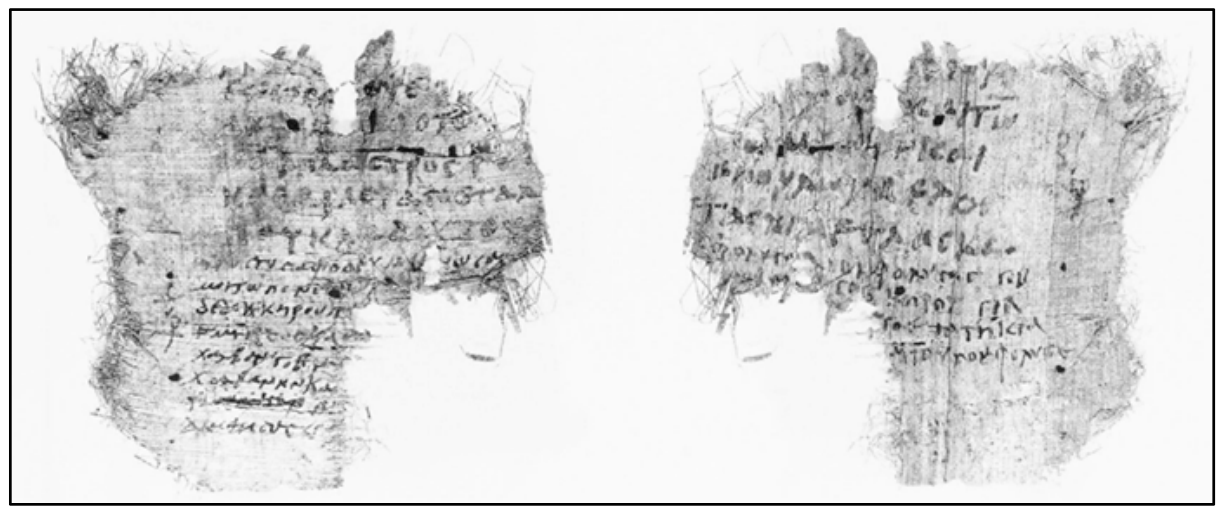

Fig. 9: P.Mich. XVII $758 \mathrm{H} \mathrm{r} / \mathrm{v}$ : main text with recipes taken from other authors; marginal annotations and additions with a reference system of coronides and other graphical marks (YOUTIE 1996, Pl. 8).

193 HANSON 2010, 197-8, and 1997, 303.

194 HANSON 2010, 197-8, and 1997, 303.

195 HANSON 2010, 199; cf. also the observations by BONATI 2016b, 60-9.

196 Cf. ANDORLINI 2003, 26-7.

197 The DCLP digital edition of the Michigan Medical Codex has been encoded by students of the Papyrology class (F. Bertonazzi, F. Corazza, L. Rizzardi, M.E. Galaverna, C. Bottioni, M. Catania, F. Giraldi, P. Lillo, G. Saccani, E. Mazzetti, L. Mazzolari, A. Brunazzi, E. Angolani, N. Pajares Collado, C.M. Ferrari) under the supervision of L. Iori, M. Centenari, I. Bonati, and N. Reggiani. 


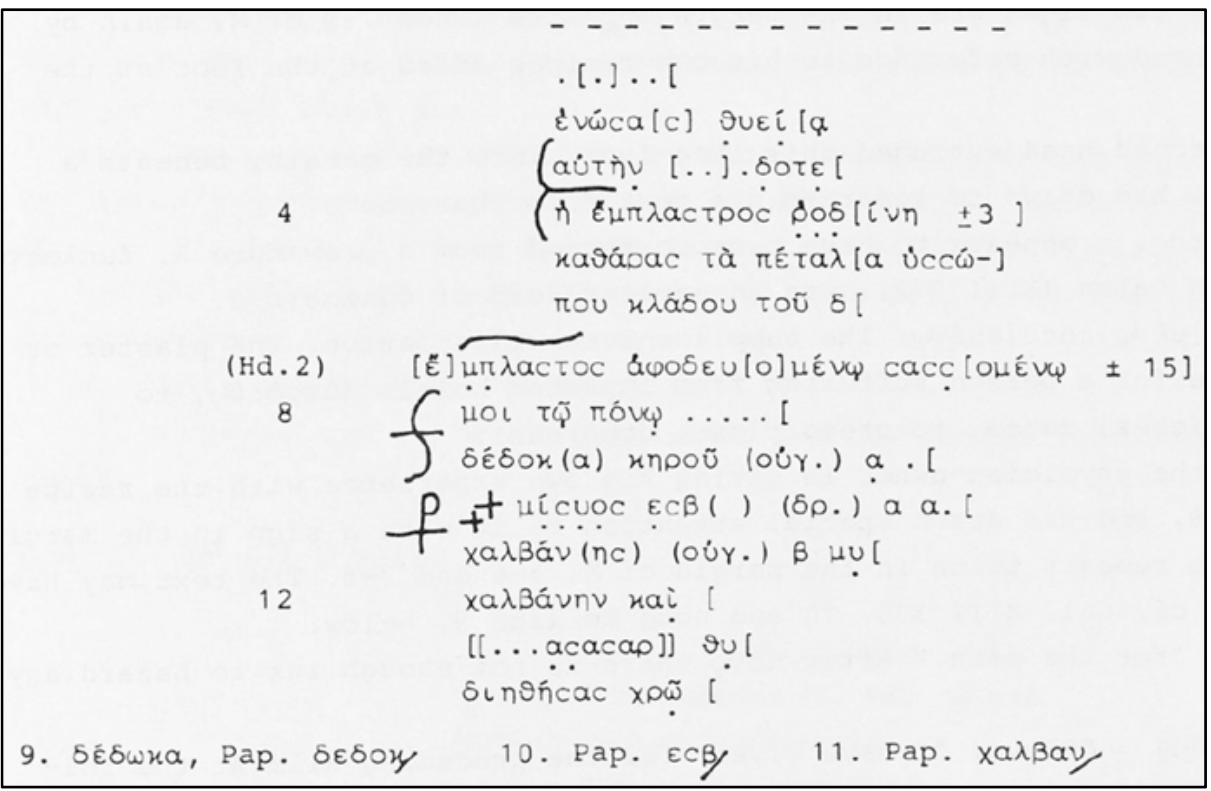

Fig. 10: Printed edition of P.Mich. XVII 758 H r (YOUTIE 1996, 59).

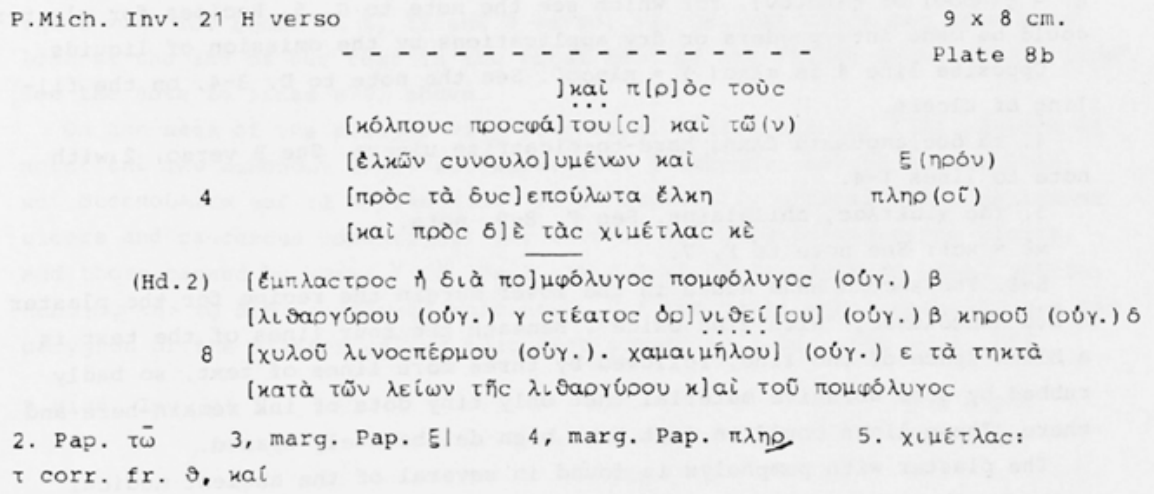

Fig. 11: Printed edition of P.Mich. XVII 758 H v (YOUTIE 1996, 61). 


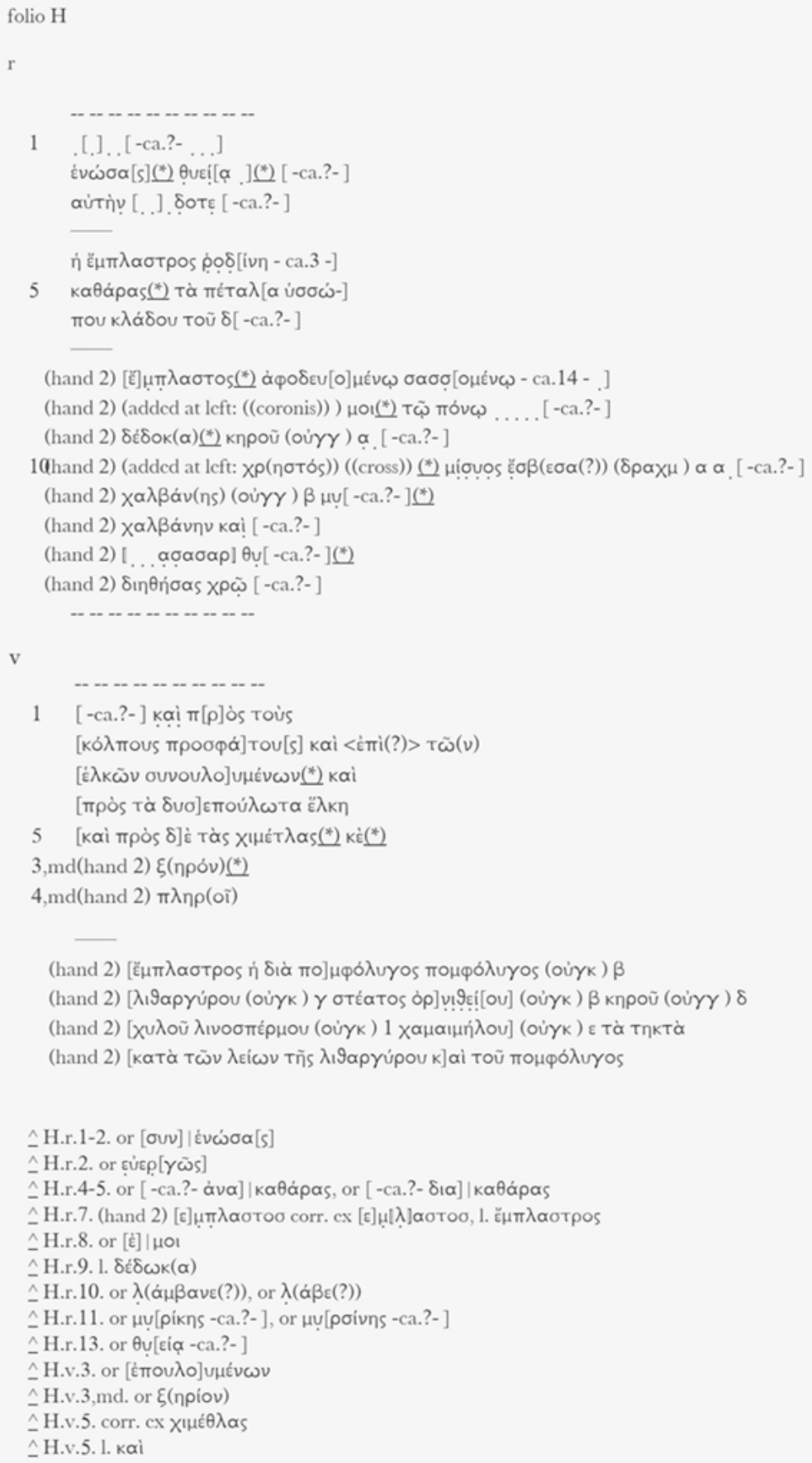

Fig. 12: DCLP digital edition of P.Mich. XVII $758 \mathrm{H} \mathrm{r} / \mathrm{v}$ (http://www.litpap.info/dclp/59332). 


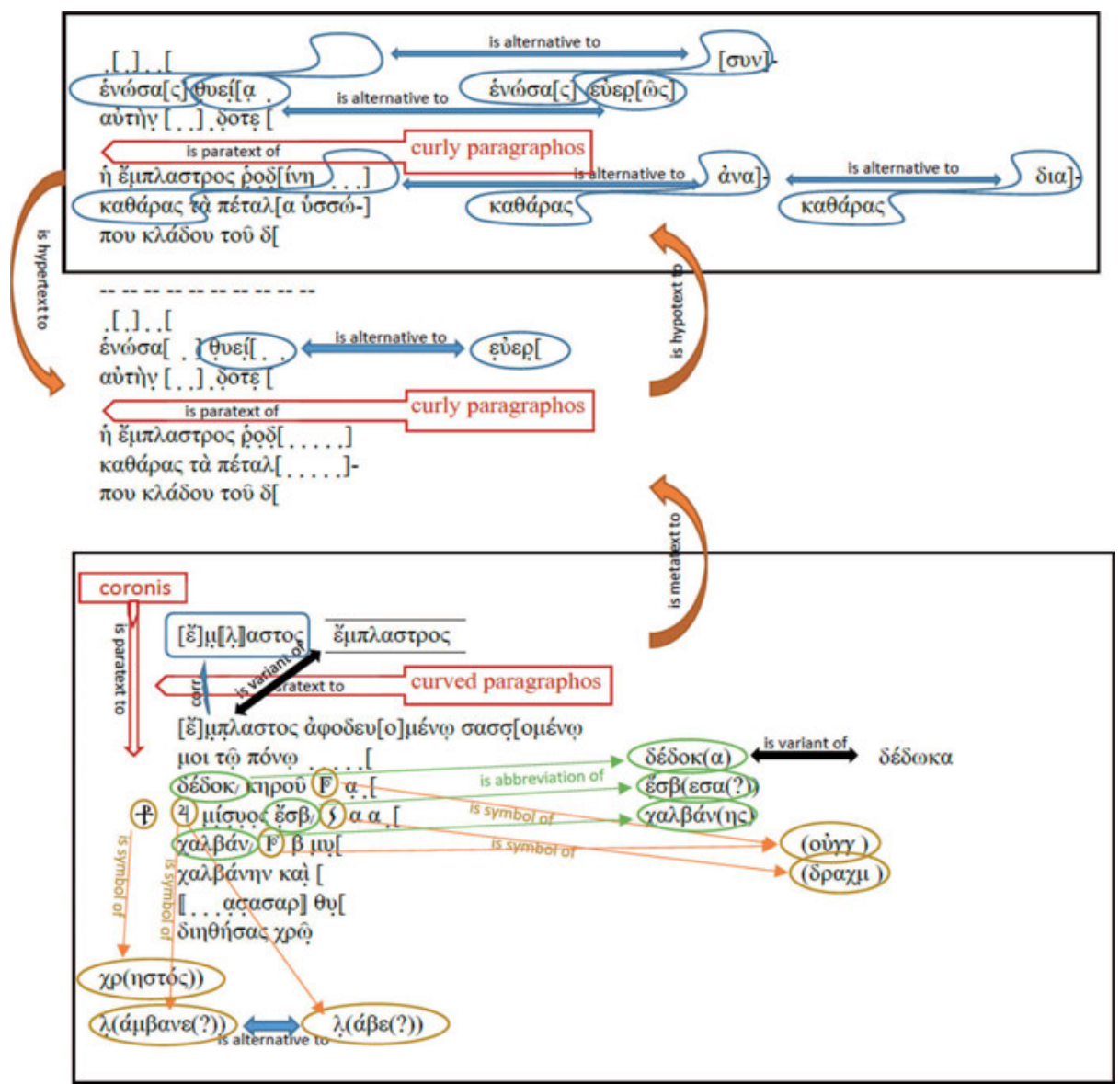

Fig. 13: Tentative ontology model for P.Mich. XVII $758 \mathrm{H} \mathrm{r}$. Some layers are simplified; note that in the metatext layer (below) the hypotext and the hypertext are merged (and some editorial supplements and alternatives are missing) in order to give space to the annotation of abbreviations and symbols, which clearly shows their intensive deployment by the second hand (= the owner of the

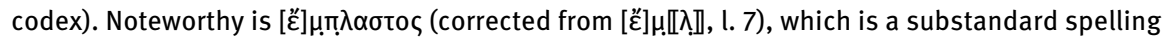
variant of the more common $\varepsilon$ $\mu \pi \lambda \alpha \sigma \tau \rho \circ$ : as already noted by YoutIE 1996, ad loc., " $\varepsilon$ " $\mu \pi \lambda \alpha \sigma \tau o \varsigma$, according to Galen (XIII 372 [K.]), was an earlier form of عُ $\mu \pi \lambda \alpha \sigma \tau \rho \circ$ ". Moreover, the entire metatextual paragraph must be noted as written in ekthesis in the bottom margin, which is marked line by line in the Leiden + code. Here, it would suffice to encode it as a marginal metatext and to connect it to an ekthesis paratext layer (see the following sample). 


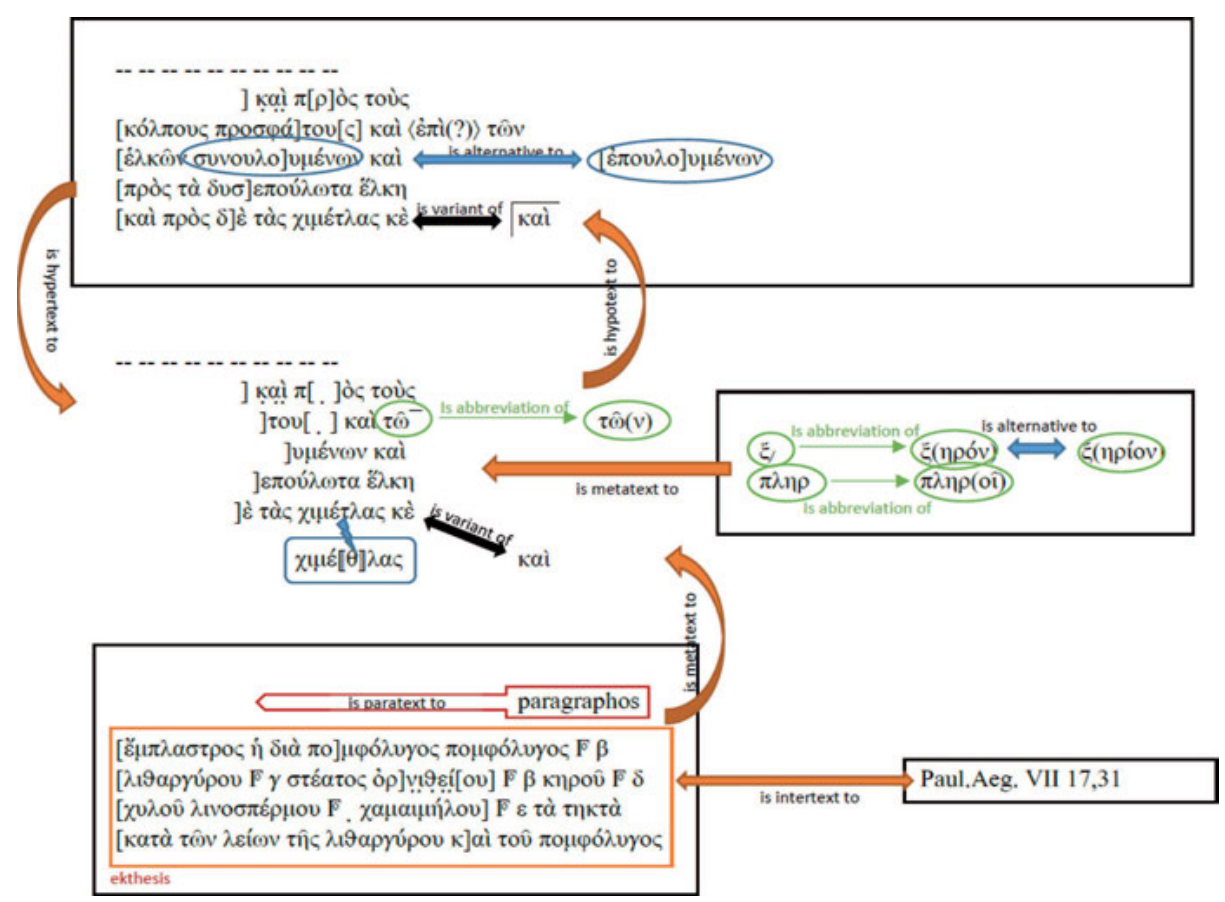

Fig. 14: Tentative ontology model for P.Mich. XVII $758 \mathrm{H} \mathrm{v}$. Some layers are simplified; in the metatext layer (below) the hypotext and the hypertext are merged as in the preceding sample, but here symbols are not handled in order to give space to the ekthesis paratext layer and to the intertextual layer, since the recipe added to the bottom margin (II. 6-9) closely recalls (in the typology and number of the ingredients and in their quantities) a passage of Paul of Aegina (VII $17,31)$. Note also how the right-hand-margin additions are handled as metatext layer connected to II. 3-4 of the main text, whereas the Leiden+ markup does not handle the situation properly (marginal lines can be added within the text, or at the end, but in both cases some metatextual

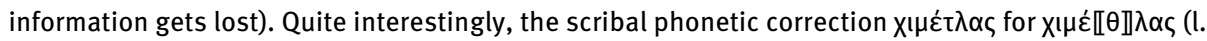
5) attests to a preference for a form used by Paul (e.g. III 79,1) rather than other medical writers (e.g. Orib. Coll. IV 615,19; 620; Syn. VII 45; Gal. XIII 380,5 K.; 383,17 K.).

Admittedly, printed or printed-like media are physically limited as to dealing with complex degrees of textuality, and adopted the critical edition model as a way of fixing a text for scholarly purposes. On the contrary, ancient textual criticism - recognizable in the commentaries, the annotations, the philological interventions, the paratextual care deployed by the ancient scribes and scholars - was apparently a way to pass down knowledge, i.e. a means of text transmission rather than text reconstruction and fixation. Nowadays, thanks to the digital tools, we do have the occasion to develop digital infrastructures in a hyper-dimensional cyberspace to overcome traditional criticism and its shortcomings, and to conceive a digital critical edition with 
deeper and deeper levels of text analysis (markup tagging, linguistic or semantic annotation layers, in-text information). ${ }^{198}$

As BODARD - GARCÉS 2009 argue, a major advantage of digital editions (namely the papyrological ones) is the possibility to get back to the materiality of texts, avoiding the philological necessity of reconstructing an archetype and focusing on text transmission instead. "[A]ttention would be better focused on how to present a text with multiple manuscript witnesses to a reader in a digital environment”: 199

Digital editions may stimulate our critical engagement with such crucial textual debate. They may push the classic definition of the 'edition' by not only offering a presentational publication layer but also by allowing access to the underlying encoding of the repository or database beneath. Indeed, an editor need not make any authoritative decisions that supersede all alternative readings if all possibilities can be unambiguously reconstructed from the base manuscript data, although most would in practice probably want to privilege their favoured readings in some way. The critical edition, with sources fully incorporated, would potentially provide an interactive resource that assists the user in creating virtual research environments. ${ }^{200}$

Thus, the authors hop[e] that digital or virtual research environments would support the creation of 'ideal' digital editions where the editor does not have to decide on a 'best text' since all editorial decisions could be linked to their base data (e.g., manuscript images, diplomatic transcriptions)..$^{201}$

Similarly, NicHOLs 2009 states that the ideal of the archetype text and textual criticism is an "artefact of analogue scholarship" consequent to the limitations of the printed pages. Conversely,

[t]he Internet has altered the equation by making possible the study of literary works in their original configurations. We can now understand that manuscripts designed and produced by scribes and artists - often long after the death of the original poet - have a life of their own. It was not that scribes were 'incapable' of copying texts word-for-word, but rather that this was not what their culture demanded of them. [...]. [I]t requires rethinking concepts as fundamental as authorship, for example. Confronted with over 150 versions of the work, no two quite alike, what becomes of the concept of authorial control? And how can one assert with certainty which of the 150 or so versions is the 'correct' one, or even whether such a concept even makes sense in a preprint culture..$^{202}$

Thus, the digitization of manuscripts and the creation of digital critical editions have not only provided new opportunities for textual criticism but also might even be viewed as enabling a

198 L. Berkes, in his chapter for this volume, asks: "should we expect online editions to conform to the norms of traditional printed editions or should we accept them as a slightly different form of publication?"

199 BABEU 2011, 36.

200 BODARD - GARCÉS 2009, 96.

201 BABEU 2011, 36.

202 NiCHOLS 2009. 
type of criticism that better respects the traditions of the texts or objects of analysis themselves ${ }^{203}$.

Consider also the reflections of CAYLESS 2010 about the prominence of the transmission of content on its external appearance:

\footnotetext{
[p]agination is a relatively fragile construct in the digital age”, and textual "accretions" like commentaries, glosses and marginal notes, progressively gathered around the main text in its historical transmission, can be effectively encoded and represented in digital editions that not simply replicate print technologies. ${ }^{204}$
}

When we note (again after CAYLESS 2010, 162) that - functionally and theoretically traditional commentary is a hypertext in print, ${ }^{205}$ everything comes full circle, and it appears clearly how the new technologies can produce a very similar outcome as the ancient textual criticism described above. It can be argued, therefore, that a digital critical edition can develop into something completely different from the somehow 'old-fashioned' printed critical edition: namely, a further step in the fluid textual transmission of ancient sources.

\section{Bibliography}

ANDORLINI, I. (1981), Ricette mediche nei papiri: note d'interpretazione e analisi di ingredienti

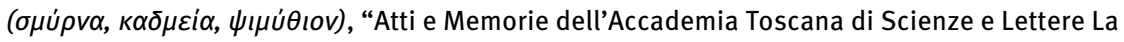

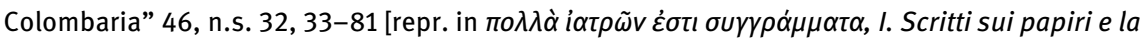
medicina antica, a c. di N. Reggiani, Firenze 2017, 37-48, and II. Edizioni di papiri medici greci, a c. di N. Reggiani, Firenze 2018, forthcoming].

ANDORLINI, I. (1993), L'apporto dei papiri alla conoscenza della scienza medica antica, in Aufstieg und Niedergang der römischen Welt, II 37.1, hrsg. von W. Haase und H. Temporini, Berlin - New York, 458-562.

ANDORLINI, I. (1997a), Progetto per il Corpus dei Papiri Greci di Medicina, in Akten des 21. Internationalen Papyrologenkongresses (Berlin 1995), hrsg. von B. Kramer, W. Luppe, H. Maehler und G.

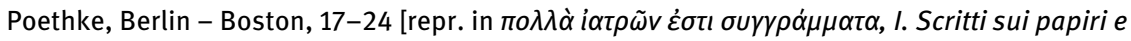
la medicina antica, a c. di N. Reggiani, Firenze 2017, 337-43].

ANDORLINI, I. (1997b), Trattato o catechismo? La tecnica della flebotomia in PSI inv. CNR 85/86, in 'Specimina' per il Corpus dei Papiri Greci di Medicina. Atti dell'incontro di studio (Firenze

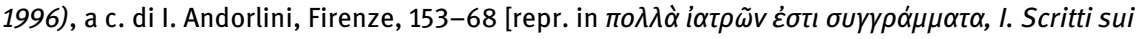
papiri e la medicina antica, a c. di N. Reggiani, Firenze 2017, 117-30].

203 BABEU 2011, 39.

204 CAYLESS 2010, 148. Quite interestingly, Cayless' picture exactly parallels the arguments brought by HANSON 1997 apropos of the transmission of ancient medical fragmentary texts, and the "accretive model of composition" (e.g. p. 305, see above) that she envisages to overcome the limits and rigidities of stemmatological interpretations.

205 Cf. also CAYLESS 2010, 170. 
ANDORLINI, I. (1999), Testi medici per la scuola: raccolte di definizioni e questionari nei papiri, in I testi medici greci. Tradizione e ecdotica. Atti del III Convegno internazionale (Napoli 1997), a c. di

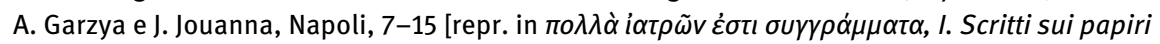
e la medicina antica, a c. di N. Reggiani, Firenze 2017, 286-93].

ANDORLINI, I. (2000), Codici papiracei di medicina con scolî e commento, in Le commentaire entre tradition et innovation. Actes du colloque international de l'Institut des Traditions Textuelles (Paris et Villejuif 1999), éd. par M.-O. Goulet-Cazé, Paris, 37-52.

ANDORLINI, I. (2001), Hippocrates, De fracturis 37 (PAberd 124r), in Greek Medical Papyri I, ed. by I.

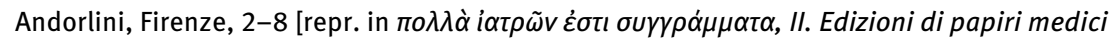
greci, a c. di N. Reggiani, Firenze 2018, forthcoming].

ANDORLINI, I. (2003), L'esegesi del libro tecnico: papiri di medicina con scolî e commento, in Papiri

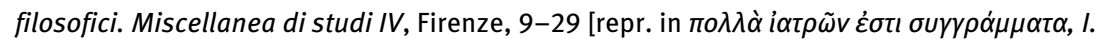
Scritti sui papiri e la medicina antica, a c. di N. Reggiani, Firenze 2017, 294-317].

ANDORLINI, I. (2006), Il 'gergo' grafico ed espressivo della ricettazione medica antica, in Medicina e

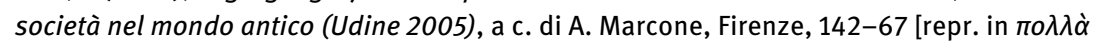

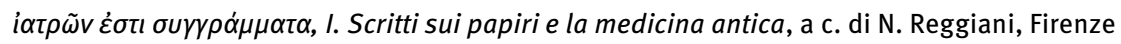
2017, 15-36].

ANDORLINI, I. (2014), Ippocratismo e medicina ellenistica in un trattato medico su papiro, in Hippocrate et les hippocratismes: médecine, religion, société. Actes du XIVe Colloque International

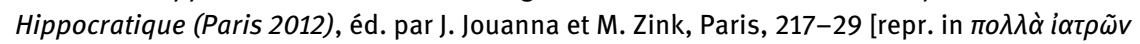

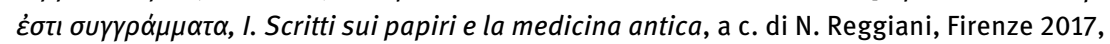
217-25].

ANDORLINI, I. (2017), Il corpus dei papiri medici online: la piattaforma editoriale, in Atti del VII Colloquio Internazionale sull'Ecdotica dei testi medici greci (Procida 2013), a c. di A. Roselli, Napoli,

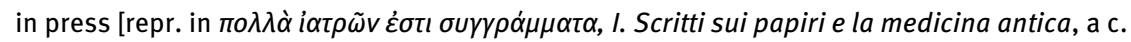
di N. Reggiani, Firenze 2017, 380-90].

ANDORLINI, I. (2018), From Prescription to Practice: The Evidence of two Medical Papyri from Roman Egypt, in Greek Medical Papyri: Text, Context, Hypertext. Proceedings of the DIGMEDTEXT International Conference (Parma 2016), ed. by N. Reggiani, Berlin - Boston, forthcoming.

ANDORLINI, I. - REGGIANI, N. (2012), Edizione e ricostruzione digitale dei testi papiracei, in Diritto romano e scienze antichistiche nell'era digitale. Convegno di studio (Firenze 2011), a c. di N. Pa-

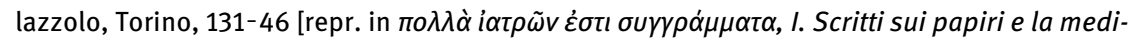
cina antica, a c. di N. Reggiani, Firenze 2018, 363-75].

AST, R. (2017), Signs of Learning in Greek Documents : The Case of spiritus asper, in NoCCHI MACEDO SCAPPATICCIO 2017, 143-58.

BABEU, A. (2011), “Rome Wasn't Digitized in a Day”: Building a Cyberinfrastructure for Digital Classics, Washington (DC).

BAGNALL, R.S. (1995), Reading Papyri, Writing Ancient History, London - New York.

BAgnalL, R.S. (2012), The Amicitia Papyrologorum in a Globalized World of Learning, in Actes du $26 e$ Congrès International de Papyrologie (Genève 2010), éd. par P. Schubert, Genève, 1-5.

BAgnALL, R.S. - GAgoS, T. (2007), The Advanced Papyrological Information System: Past, Present, and Future, in Proceedings of the 24th International Congress of Papyrology (Helsinki 2004), ed. by J. Frosen, T. Purola, and E. Salmenkivi, Helsinki, I, 59-74.

BARBIS LUPI, R. (1988), La diplè obelismene: precisazioni terminologiche e formali, in Proceedings of the XVIII Inernational Congress of Papyrology (Athens 1986), ed. by B.G. Mandilaras, Athens, II, 473-6.

BARBIS LUPI, R. (1992), Uso e forma dei segni di riempimento nei papiri letterari greci, in Proceedings of the XIXth International Congress of Papyrology (Cairo 1989), ed. by A.H.S. El-Mosalamy, Cairo, I, 503-10. 
BARBIS LUPI, R. (1994), La Paragraphos : analisi di un segno di lettura, in Proceedings of the 20th International Congress of Papyrologists (Copenhagen 1992), ed. by A. Bülow-Jacobsen, Copenhagen, 414-7.

BARNS, J.W.B. (1949), Literary Texts from the Fayum, CQ 43, 1-8.

BaUman, Z. (2000), Liquid Modernity, Malden (MA).

BAUMAN, Z. (2007), Liquid Times. Living in an Age of Uncertainty, Malden (MA).

BAUMAN, Z. (2011), Culture in a Liquid Modern World, Malden (MA).

BeLL, H.I. (1953), Abbreviations in Documentary Papyri, in Studies Presented to David Morre Robinson, Saint Louis (MO), 424-33.

BERNARDELLI, A. (2000), Intertestualità, Firenze.

Bernardelul, A. (2010), La rete intertestuale. Percorsi tra testi, discorsi e immagini, Perugia.

BERTI, M. (2012), L'intertestualità e la storiografia greca frammentaria, in Tradizione e trasmissione degli storici greci frammentari Il. Atti del Terzo Workshop Internazionale (Roma 2011), a c. di V. Costa, Tivoli (RM), 439-58.

BERTI, M. (forthcoming), Fragmentary Texts and Digital Libraries, in Philology in the Age of Corpus and Computational Linguistics, ed. by G. Crane, A. Lüdeling, and M. Berti, CHS Publication, URL: http://www.fragmentarytexts.org/wp-content/uploads/2010/07/Berti-FragmentaryTexts-and-Digiital-Libraries.pdf.

BertonazzI, F. (2018a), Il lessico degli strumenti chirurgici nei papiri greci di medicina. Dalla digitalizzazione dei testi allo studio delle parole, PhD Diss. Parma.

BERTONAZZI, F. (2018b), Edizione digitale di P. Strasb. inv. 1187: un confronto tra il testo papiraceo e la tradizione manoscritta, in Proceedings of the 28th International Congress of Papyrology (Barcelona 2016), ed. by S. Torallas Tovar and A. Nodar, Barcelona, forthcoming.

BIRD, G.D. (2010), Multitextuality in the Homeric lliad. The Witness of the Ptolemaic Papyri, Cambridge (MA) - London.

BLANCHARD, A. (1974), Sigles et abbréviations dans les papyrus documentaires grecs. Recherches de paléographie, London.

Bodard, G. - GarcÉs, J. (2009), Open Source Critical Editions: A Rationale, in Text Editing, Print, and the Digital World, ed. by M. Deegan and K. Sutherland, Farnham - Burlington (VT), 84-98.

BoLteR, J.D. (1991), The Computer, Hypertext, and Classical Studies, AJP 112, 541-5.

BonatI, I. (2015), Xút $\alpha$, in Medicalia Online, ed. by I. Andorlini, URL: http://www.papirologia.unipr.it/CPGM/medicalia/vocab/index.php?tema=141.

BOnATI, I. (2016a), Il lessico dei vasi e dei contenitori greci nei papiri. Specimina per un repertorio lessicale degli angionimi greci, Berlin - New York.

BONATI, I. (2016b), L'etichettatura del farmaco: radici antiche di una tradizione millenaria, in Medicapapyrologica. Miscellanea di studi presentati al Convegno Internazionale "Parlare la Medicina" (Parma 2016), a c. di N. Reggiani, Parma, 43-77.

BONATI, I. (2017), L'uso della metafora nella microlingua greca della medicina, in La metafora e la sua traduzione: fra riflessioni teoriche e casi applicativi, a c. di D. Astori, Parma, 83-100.

BONATI, I. (2018a), Tra composti, suffissi e neologismi nella microlingua della medicina: alcuni specimina tratti dai papiri, in Parlare la medicina: fra lingue e culture, nello spazio e nel tempo. Atti del Convegno Internazionale (Parma 2016), a c. di N. Reggiani e F. Bertonazzi, Firenze, forthcoming.

BONATI, I. (2018b), Medicalia Online: tecnicismi medici tra passato e presente, in Greek Medical Papyri: Text, Context, Hypertext. Proceedings of the DIGMEDTEXT International Conference (Parma 2016), ed. by N. Reggiani, Berlin - New York, forthcoming.

BonatI, I. (2018c), La parola delle cose: nuove voci dal passato dei papiri, in Papiri, medicina antica e cultura materiale. Contributi in ricordo di Isabella Andorlini, a c. di N. Reggiani, Parma, forthcoming.

BonatI, I. (2018d), Between Text and Context: P.Oslo II 54 Revisited, in Proceedings of the 28th International Congress of Papyrology (Barcelona 2016), ed. by S. Torallas Tovar and A. Nodar, Barcelona, forthcoming. 
BonATI, I. (2018e), Definitions and Technical Terminology in the Erôtapokriseis on Papyrus, in "Where Does It Hurt?" Ancient Medicine in Questions and Answers, ed. by M. Meeusen and E. Gielen, Leiden - Boston, forthcoming.

BonatI, I. - REgGIANI, N. (2018), Mirrors in the Greek Papyri: Question of Words, in Mirrors and Mirroring: From Antiquity to the Early Modern Period. Proceedings of the Workshop (Wien 2017), ed. by L. Diamantopoulou and M. Gerolemou, forthcoming.

BosCHETt, F. (2007), Methods to Extend Greek and Latin Corpora with Variants and Conjectures: Mapping Critical Apparatuses onto Reference Text, in Proceedings of the Corpus Linguistics Conference (Birmingham 2007), URL: http://ucrel.lancs.ac.uk/publications/CL2007/paper/150_Paper.pdf.

Brodersen, K. (1994), Hippokrates und Artaxerxes. Zu P. Oxy. 1184v, P. Berol. inv. $7094 \mathrm{v}$ und $21137 v+$ 6934v, ZPE 102, 100-10.

CAYLESS, H.A. (2010), Ktema es aiei: Digital Permanence from an Ancient Perspective, in Digital Research in the Study of Classical Antiquity, ed. by G. Bodard and S. Mahony, Farnham - Burlington (VT), 139-50.

CLARYSSE, W. (1990), Abbreviations and Lexicography, AncSoc 21, 33-44.

Colomo, D. (2017), Quantity Marks in Greek Prose Texts on Papyrus, in NoCCHI MACEDO - SCAPPATICCIO 2017, 97-126.

Colonna, A. (1954), Un antico commento ai Theriaca di Nicandro, "Aegyptus" 34, 3-26.

CoRAzZA, F. (2016), New Recipes by Heras in P.Berol.Möller 13, ZPE 198, 39-48.

CoRAzZA, F. (2018a), La digitalizzazione dei papiri medici di Antinoupolis, in Greek Medical Papyri: Text, Context, Hypertext. Proceedings of the DIGMEDTEXT International Conference (Parma 2016), ed. by N. Reggiani, Berlin - New York, forthcoming.

CorazzA, F. (2018b), The Antinoopolis Medical Papyri: A Case Study in Late Antique Medicine, PhD Diss. Berlin.

CRIBIORE, R. (1996), Writing, Teachers, and Students in Graeco-Roman Egypt, Atlanta (GA).

CRIBIORE, R. (2018), Genetic Criticism and the Papyri: Some Suggestions, in Greek Medical Papyri: Text, Context, Hypertext. Proceedings of the DIGMEDTEXT International Conference (Parma 2016), ed. by N. Reggiani, Berlin - New York, forthcoming.

DAmON, C. (2016), Beyond Variants: Some Digital Desiderata for the Critical Apparatus of Ancient Greek and Latin Texts, in Digital Scholarly Editing. Theories and Practices, ed. by M.J. Driscoll and E. Pierazzo, Cambridge (UK), 201-18.

DEGANI, E. (1992), Il mostro di Irvine, “Eikasmòs” 3, 277-8.

DEGNI, P. (1999), Per uno studio sulle abbreviazioni greche. Dalle origini al IV secolo d.C., S\&C 23, 63-74.

Del MASTRO, G. (2017), La ponctuation dans les papyrus grecs d'Herculaneum, in Signes dans les textes, textes sur les signes. Érudition, lecture et écriture dans le monde gréco-romain. Actes du colloque international (Liège 2013), éd. par G. Nocchi Macedo et M.C. Scappaticcio, Liège, 77-96.

Depauw, M. - Stolk, J. (2015), Linguistic Variation in Greek Papyri: Towards a New Tool for Quantitative Study, GRBS 55, 196-220.

DICKEY, E. (2017), Word Division in Bilingual Texts, in NoCCHI MACEDO - SCAPPATICCIO 2017, 159-76.

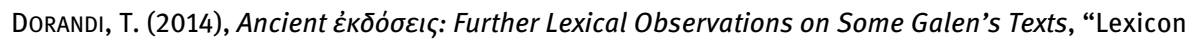
Philosophicum" 2, 1-23, URL: http://lexicon.cnr.it/index.php/LP/article/view/398.

ESSLER, H. - RIAÑo RufILANCHAS, D. (2016), 'Aristarchus X' and Philodemus: Digital Linguistic Analysis of a Herculanean Text Corpus, in Proceedings of the 27th International Congress of Papyrology (Warsaw 2013), ed. by J. Urbanik, T. Derda, and A. tajtar, Warsaw, I, 491-501.

FINGLASS, P.J. (2015), Reperformances and the Transmission of Texts, "Trends in Classics" 7, 259-76. FAUSTI, D. (1989), P.Strasb. inv. gr. 1187: testo chirurgico (Eliodoro?), "Annali della Facoltà di Lettere e Filosofia, Firenze" 10, 157-69. 
FISCHER, K.-D. (1998), Beiträge zu den pseudosoranischen Quaestiones medicinales, in Text and Tradition. Studies in Ancient Medicine and its Transmission, eds. K.-D. Fischer, D. Nickel, and P. Potter, Leiden - Boston - Köln, 1-41.

FUNARI, R. (2017), Segni di interpunzione e di lettura nei frammenti storici latini da papiro e pergamena rinvenuti nell'Egitto, in NOCCHI MACEDO - SCAPPATICCIO 2017, 177-202.

GAGOS, T. (2001), The University of Michigan Papyrus Collection: Current Trends and Future Perspectives, in Atti del XXII Congresso Internazionale di Papirologia (Firenze 1998), a c. di I. Andorlini, G. Bastianini, M. Manfredi e G. Menci, Firenze, II, 511-37.

Garofalo, I. - Fortuna, S. - LAMI, A. - Roselli, A. (2010), curr., Sulla tradizione indiretta dei testi medici greci: le traduzioni. Atti del III seminario internazionale (Siena 2009), Pisa - Roma.

GeNETTE, G. (1992), The Architext: An Introduction, Berkeley (CA) [Introduction à l'architexte, Paris 1979].

GeNETTE, G. (1997), Palimpsests: Literature in the Second Degree, Lincoln (OR) [Palimpsestes: la littérature au second degré, Paris 1982].

GIGNAC, F.T. (1976), A Grammar of the Greek Papyri of the Roman and Byzantine Periods, I: Phonology, Milano.

GonIS, N. (1009), Abbreviations and Symbols, in The Oxford Handbook of Papyrology, ed. by R.S. Bagnall, Oxford, 170-8.

HANSON, A.E. (1970), P. Antinoopolis 184: Hippocrates, Diseases of Women, in Proceedings of the Twelfth International Congress of Papyrology, ed. by D.H. Samuel, Toronto, 213-22.

HANSON, A.E. (1985), Papyri of Medical Content, YCS 28, 25-47.

HANSON, A.E. (1996), Introduction, in YoutIE 1996, xv-xxv.

HANSON, A.E. (1997), Fragmentation and the Greek Medical Writers, in Collecting Fragments / Fragmente Sammeln, ed. by G.W. Most, Göttingen, 289-314

HANSON, A.E. (1998), Galen: Author and Critic, in Editing Texts / Texte edieren, ed. by G.W. Most, Göttingen, 22-52.

Hanson, A.E. (2002), Papyrology: A Discipline in Flux, in Disciplining Classics / Altertumwissenschaft als Beruf, ed. by G.W. Most, Göttingen, 191-206.

HANSON, A.E. (2010), Doctors' Literacy and Papyri of Medical Content, in Hippocrates and Medical Education, ed. by M. Horstmanshoff, Leiden - Boston, 187-204.

HANSON, A.E. - MATtERn, S.P. (2001), Medical Catechism, in Greek Medical Papyri I, ed. by I. Andorlini, Firenze, 71-83.

JÖRDENS, A. (2017), Entwurf und Reinschrift - oder: Wie bitte ich um Entlassung aus der Untersuchungshaft, "Chiron" 47, 271-302.

KollesCH, J. (1963), Untersuchungen zu den pseudogalenischen Definitiones Medicae, Berlin.

LAMÉ, M. (2014), Primary Sources of Information, Digitization Processes and Dispositive Analysis, in Proceedings of the Third AIUCD Annual Conference on Humanities and Their Methods in the Digital Ecosystem (Bologna 2014), URL: https://doi.org/10.1145/2802612.2802645.

LEITH, D. (2007), A Medical Treatise "On Remedies"? P.Turner 14 Revised, BASP 44, 125-35.

LÜDELING, A. (2011), Corpora in Linguistics: Sampling and Annotation, in Going Digital. Evolutionary and Revolutionary Aspects of Digitization, ed. by K. Grandin, New York, 220-43.

LÜDELING, A. - KYTÖ, M. (2008-09), eds., Corpus Linguistics. An International Handbook, I-II, Berlin.

LUISELLI, R. (2010), Authorial Revision of Linguistic Style in Greek Papyrus Letters and Petitions (AD IIV), in The Language of the Papyri, ed. by T.V. Evans and D.D. Obbink, Oxford, 88-94.

MACÉ, C. - BARET, P. - BozZI, A. - CIGNONI, L. (2006), eds., The Evolution of Texts: Confronting Stemmatological and Genetical Methods. Proceedings of the International Workshop (Louvain-la-Neuve 2004), Pisa - Roma.

MAGDELAINE, C. (2004), Un nouveau questionnaire ophtalmologique (PStrasb gr. inv. 849), in Testi medici su papiro. Atti del Seminario di studio (Firenze 2002), a c. di I. Andorlini, Firenze, 63-77. 
MAGNANI, M. (2008), "Sapere ex indicibus", in Scienze umane e cultura digitale. Atti della XVI Settimana della Cultura Scientifica (Parma 2006), Fiesole (FI), 127-38.

MANETTI, D. - ROSELLI, A. (1994), Galeno commentatore di Ippocrate, in Aufstieg und Niedergang der römischen Welt, II 37/2, hrsg. von H. Temporini, Berlin, 1557-65.

MANIACI, M. (2002), “La serva padrona". Interazioni fra testo e glossa nella pagina del manoscritto in Talking to the Text: Marginalia from Papyri to Print. Proceedings of the Conference (Erice 1998), ed. by V. Fera, G. Ferraù, and S. Rizzo, Messina, I, 3-35.

Maravela, A. - Leith, D. (2007), A Medical Catechism on Tumours from the Collection of the Oslo University Library, in Proceedings of the 24th International Congress of Papyrology (Helsinki 2004), ed. by J. Frösén, T. Purola, and E. Salmenkivi, Helsinki, 637-50.

MaraVela, A. - RegGiani, N. (2018), Medical Scribes at Work: Exploring Linguistic Variation in Greek Medical Papyri, in Act of the Scribe: Interfaces between Scribal Work and Language Use. Proceedings of the Workshop (Athens 2017), ed. by S. Dahlgren, H. Halla-aho, M. Leiwo, M. Vierros, Helsinki, forthcoming.

MARGANNE, M.-H. (1980), Une étape dans la transmission d'une préscription médicale: $P$. Berl. Möller 13, in Miscellanea papyrologica, a c. di R. Pintaudi, Firenze, 179-83.

MARGANNE, M.-H. (1981a), Inventaire analytique des papyrus grecs de medecine, Genève.

MARganNe, M.-H. (1981b), Un fragment du medecin Herodote: P. Tebt. II 272, in Proceedings of the XVI Int. Congr. of Papyrology (New York 1980), Chico, 73-8.

Marganne, M.-H. (1986), La 'Cirurgia Eliodori' et le P. Genève inv. 111, "Etudes de Lettres", 65-73.

MARGANNE, M.-H. (1998), La chirurgie dans l'Égypte gréco-romaine d'après les papyrus littéraires grecs, Leiden - Boston - Köln.

MARGANNE, M.-H. (2004), Le livre medical dans le monde gréco-romain, Liège.

Marganne, M.-H. - Mertens, P. (1997), Medici et Medica. 2e edition (Etat au 15 janvier 1997 du fichier MP3 pour les papyrus medicaux litteraires), in 'Specimina' per il Corpus dei Papiri Greci di Medicina. Atti dell'Incontro di studio (Firenze 1996), a c. di I. Andorlini, Firenze, 3-71.

MCNAMEE, K. (1981), Abbreviations in Greek Literary Papyri and Ostraca, Chico (CA).

MCNAMEE, K. (1985), Abbreviations in Greek Literary Papyri and Ostraca: Supplement, with List of Ghost Abbreviations, BASP 22, 205-25.

MCNAMEE, K. (2007), Annotations in Greek and Latin Texts from Egypt, Oakville (CT)

MCNAMEE, K. (2017), Sigla in Late Greek Literary Papyri, in NoCCHI MACEDO - SCAPPATICCIO 2017, 127-42.

MeSSERI SAVORELLI, G. - PINTAUDI, R. (2002), I lettori dei papiri: dal commento autonomo agli scolii, in Talking to the Text: Marginalia from Papyri to Print. Proceedings of the Conference (Erice 1998), ed. by V. Fera, G. Ferraù, and S. Rizzo, Messina, I, 37-57.

NIEDDU, G.F. (1992), Il ginnasio e la scuola: scrittura e mimesi del parlato, in Lo spazio letterario della Grecia antica, a c. di G. Cambiano, L. Canfora e D. Lanza, Roma, I.1, 555-85.

NielSen, E. (2000), A Catalog of Duplicate Papyri, ZPE 129, 187-214.

NOCCHI MACEDO, G. - SCAPPATICCIO, M.C. (2017), édd., Signes dans les textes, textes sur les signes. Érudition, lecture et écriture dans le monde gréco-romain. Actes du colloque international (Liège 2013), Liège.

NodAR Domínguez, A. (2017), Los signos de lectura más antiguos en papiro, in NOCCHI MACEDO - SCAPPATICCIO 2017, 61-76.

NUTTON, V. (1972), Galen and Medical Autobiography, PCPS 18, 50-62.

Nutron, V. (1990), The Patient's Choice: A New Treatise by Galen, CQ 40, 236-57.

OWENS, T. (2011), Defining Data for Humanists: Text, Artifact, Information or Evidence?, “Journal of Digital Humanities” 1.1, URL: http://journalofdigitalhumanities.org/1-1/defining-data-forhumanists-by-trevor-owens.

PASSAROTI, M. (2006), Towards Textual Drift Modelling in Computational Philology, in MACÉ - BARET BOZZI-CIGNONI 2006, 63-88. 
PETIT, C. (2009), Galien: Le médecin. Introduction, Paris.

PIERAZZO, E. (2008), Digital Genetic Editions: The Encoding of Time in Manuscript Transcription, in Text Editing, Print and the Digital World. Digital Research in the Arts and Humanities, ed. by M. Deegan and K. Sutherland, Aldershot, 169-86.

Polacco, M. (1998), L'intertestualità, Roma - Bari.

PORTER, S. - O'DONNELL, M.B. (2010), Building and Examining Linguistic Phenomena in a Corpus of Representative Papyri, in The Language of the Papyri, ed. by T.V. Evans and D.D. Obbink, Oxford 2010, 287-311.

RegGIANI, N. (2015), A Corpus of Literary Papyri Online: the Pilot Project of the Medical Texts via SoSOL, in Antike Lebenswelten Althistorische und papyrologische Studien, hrsg. von R. Lafer und K. Strobel, Berlin - New York, 341-52.

RegGianI, N. (2016a), The Corpus of Greek Medical Papyri and Digital Papyrology: New Perspectives from an Ongoing Project, in Altertumswissenschaften in a Digital Age: Egyptology, Papyrology and beyond. Proceedings of a Conference and Workshop in Leipzig (November 2015), ed. by M. Berti and F. Naether, Leipzig, URL: http://nbn-resolving.de/urn:nbn:de:bsz:15-qucosa-201726.

REGGIANI, N. (2016b), Catechism, in Medicalia Online, ed. I. Andorlini, URL: http://www.papirologia.unipr.it/CPGM/medicalia/vocab/index.php?tema=8.

RegGianI, N. (2016c), Data Processing and State Management in Late Ptolemaic and Roman Egypt: The Project 'Synopsis' and the Archive of Menches, in Proceedings of the 27th International Congress of Papyrology (Warsaw 2013), ed. by. T. Derda, A. tajtar, and J. Urbanik, Warsaw, III, 1415-44.

ReGGIANI, N. (2017), Digital Papyrology I. Tools, Methods and Trends, Berlin - New York.

RegGIANI, N. (2018a), Linguistic and Philological Variants in the Papyri: A Reconsideration in Light of the Digitization of the Greek Medical Papyri, in Greek Medical Papyri - Text, Context, Hypertext. Proceedings of the DIGMEDTEXT International Conference (Parma 2016), ed. by N. Reggiani, Berlin - New York, forthcoming.

REGGIANI, N. (2018b), The Corpus of Greek Medical Papyri Online and the Digital Edition of Ancient Documents, in Proceedings of the 28th International Congress of Papyrology (Barcelona 2016), ed. by S. Torallas Tovar and A. Nodar, Barcelona, forthcoming.

REGGIANI, N. (2018c), The Digital Edition of Ancient Sources as a Further Step in the Textual Transmission, in Proceedings of the Workshop "Digital Classics III: Re-thinking Text Analysis" (Heidelberg 2017), ed. by A. Novokhatko, S. Chronopoulos, and F.K. Maier, forthcoming.

REGGIANI, N. (2018d), Isabella Andorlini, la papirologia medica e il progetto DIGMEDTEXT, in Papiri, medicina antica e cultura materiale. Contributi in ricordo di Isabella Andorlini, a cura di N. Reggiani, Parma, forthcoming.

REGGIANI, N. (2018e), Ancient Doctors' Literacies and the Digital Edition of Papyri of Medical Content, “Classics@”, forthcoming.

REGGIANI, N. (2018f), Ispezioni e perizie ufficiali nell'Egitto romano: il corpus dei rapporti professionali (prosphōnēseis), in Lavoro manuale e lavoro intellettuale nella società romana, a c. di A. Marcone e P. Porena, Roma, forthcoming.

REGGIANI, N. (2018g), Transmission of Recipes and Receptaria in Greek Medical Writings on Papyrus Between Ancient Text Production and Modern Digital Representation, in "Cupis volitare per auras": Books, Libraries and Textual Transmission from the Ancient to the Medieval World. Proceedings of the First Postgraduate Conference (Bari 2016), ed. by E. Barile, R. Berardi, N. Bruno, M. Filosa, and L. Fizzarotti, forthcoming.

REGGIANI, N. (2018h), Digitizing Medical Papyri in Question-and-Answer Format, in "Where Does It Hurt?" Ancient Medicine in Questions and Answers, ed. by E. Gielen and M. Meeusen, Leiden Boston, forthcoming.

REGGIANI, N. (2018i), Herbal, in Medicalia Online, ed. I. Andorlini, URL: http://www.papirologia.unipr.it/CPGM/medicalia/vocab/index.php?tema=11, forthcoming. 
RegGianI, N. (2018j), Prescrizioni mediche e supporti materiali nell'Antichità, in Parlare la medicina: fra lingue e culture, nello spazio e nel tempo. Atti del Convegno Internazionale (Parma 2016), a cura di N. Reggiani e F. Bertonazzi, Firenze, forthcoming.

Riaño Rufilanchas, D. (2014), The “Grammatically Annotated Philodemus" Project, CErc 44, $155-65$. Romanello, M. - Berti, M. - Boschetti, F. - BABeu, A. - Crane, G. (2009), Rethinking Critical Editions of Fragmentary Texts by Ontologies, in Rethinking Electronic Publishing: Innovation in Communication Paradigms and Technologies. Proceedings of 13th International Conference on Electronic Publishing (Milano 2009), Milano, 155-74, URL: https://elpub.architexturez.net/doc/oaielpub-id-158-elpub2009.

Roued-Cunliffe, H. (2009), Textual Analysis Using XML: Understanding Ancient Textual Corpora, in 5th IEEE Conference on e-Science 2009, URL: http://esad.classics.ox.ac.uk/IEEE_Paper_ HRa19b.pdf_\%3b\%20modification-date\%3d_Thu\%2c\%2007\%20Jul\%202011\%2013_19_56\% 20\%2b0000_\%3b\%20size\%3d1625627\%3b?option=com_docman\&task=doc_download\&gid $=30$ \&Itemid $=78$.

SAVIGNAGO, L. (2008), Eisthesis. Il sistema dei margini nei papiri dei poeti tragici, Alessandria.

SCHUBERT, P. (2009), Editing a Papyrus, in The Oxford Handbook of Papyrology, ed. by R.S. Bagnall, Oxford, 197-215.

SINCLAIR, J. (1996), EAGLES [Expert Advisory Group on Language Engineering Standards]: Preliminary Recommendations on Corpus Typology, URL: http://www.ilc.cnr.it/EAGLES96/corpustyp/corpustyp.html.

Stolk, J. (2015a), Case Variation in Greek Papyri. Retracing dative case syncretism in the language of the Greek documentary papyri and ostraca from Egypt (300 BCE - 800 CE), PhD Diss. Oslo.

Stolk, J. (2015b), Dative by Genitive Replacement in the Greek Language of the Papyri: A Diachronic Account of Case Semantics, “Journal of Greek Linguistics” 15, 91-121.

Stoop, J. (2014), Two Copies of a Royal Petition from Kerkeosiris, ZPE 189, 185-93.

TOMASI, F. - ZAJA, P. (2002), Proposte per un'edizione ipertestuale di postillati cinquecenteschi, in Talking to the Text: Marginalia from Papyri to Print. Proceedings of the Conference (Erice 1998), ed. by V. Fera, G. Ferraù, and S. Rizzo, Messina, II, 721-52.

Tomsin, A. (1970), Les papyrologues et le travail papyrologique par ordinateur, in Proceedings of the Twelfth International Congress of Papyrology, ed. by D.H. Samuel, Toronto, 471-84.

Totelin, L.M.V. (2009a), Hippocratic Recipes. Oral and Written Transmission of Pharmacological Knowledge in Fifth- and Fourth-Century Greece, Leiden - Boston.

Totelin, L.M.V. (2009b), Galen's Use of Multiple Manuscript Copies in His Pharmacological Treatises, in Authorial Voices in Greco-Roman Technical Writing, eds. L. Taub and A. Doody, Trier, 81-92.

TURNER, E.G. (1987), Greek Manuscripts of the Ancient World. Second Edition Revised and Enlarged, ed. by P.J. Parsons, London [1970].

VAnNINI, L. (2012), Papiri con edizioni commentate, in Actes du 26e Congrès International de Papyrologie (Genève 2010), éd. par P. Schubert, Genève, 801-5.

VÉRONIS, J. (2000), ed., Parallel Text Processing: Alignment and Use of Translation Corpora, Dordrecht.

WILLIS, W.H. (1984), The Duke Data Bank of Documentary Papyri, in Atti del XVII Congresso Internazionale di Papirologia (Napoli), Napoli, I, 167-73.

WORTON, M. - STILL, J. (1990), Intertextuality. Theories and Practices, Manchester - New York.

YOUTIE, H.C. (1963), The Papyrologist: Artificer of Fact, GRBS 4, 19-32.

YoutIE, L.C. (1996), The Michigan Medical Codex, ed. by A.E. Hanson, Atlanta (GA) [= The Michigan Medical Codex, 1986-87, ZPE 65, 123-49; 66, 149-56; 67, 83-95; 69, 163-9; 70, 73-103].

YUEn-Collingridge, R. - ChOAT, M. (2012), The Copyist at Work: Scribal Practice in Duplicate Documents, in Actes du 26e Congres international de papyrologie (Genève 2010), éd. par P. Schubert, Genève, 827-34. 
